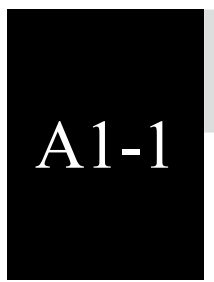

\title{
バルプロ酸の胎生期曝露がもたらす授乳期ラットの海馬局所神 経回路機能への影響
}

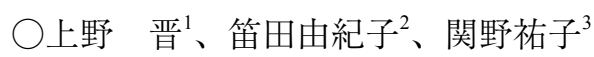

（産業医大・ ${ }^{1}$ 産生研・職業性中毒、 ${ }^{2}$ 産業保健 ·作業環境計測制御、 ${ }^{3}$ 国立衛研・薬理)

【目的】化学物質の発達神経毒性評価については、妊娠動物（ラット・マウス）を用いる発達神経毒性試 験ガイドラインがOECD（経済協力開発機構）やEPA（米国環境保護庁）によって制定されているが、多 大な費用と時間を必要とすることから in vitro系による新規評洒法の確立が望まれている。本研究では発 達神経毒性を早期に評価できる新たな指標の確立を目的として、自閉症モデル動物として知られている バルプロ酸（VPA）の胎生期曝露モデルラットを用い、その授乳期における海馬局所回路の機能を解析 した。

【方法】妊娠Wistarラット（day 15）に300 mg/kgのVPAを単回経口投与（VPA胎生期曝露群、対照群とし て生理食塩水の単回経口投与）し、出生後日齢（PND）13からPND18の雄性仔ラットから海馬スライス 標本を作製した。海馬CA1領域から集合シナプス後電位（fEPSP slope）および集合スパイク電位（PS） の同時記録を行い、入力線維領域の単回刺激に対する応答性を興奮系の評価指標として、また 2 連続刺激 に対する応答性の変化率（フィードバック抑制）を抑制系の評価指標として、対照群とVPA胎生期曝露 群とで比較検討した。

【結果と考察】対照群ではPND15～16の時期に海馬CA1領域で単回刺激に対する応答性が充進したが、 VPA胎生期曝露群ではPND14から応答性が充進していた。さらに対照群のPND13〜14の時期では出現し ていないフィードバック抑制が、VPA胎生期曝露群ではすでに出現していることが認められた。以上の 結果から、発達神経毒性を生じるVPAの胎生期曝露により、成長後の社会行動異常が出現する以前に授 乳期の海馬における局所神経回路機能の早期立進が出現することが判明した。胎生期曝露モデル動物に おいて、成長前の授乳期での海馬局所神経回路機能の評価が新たな発達神経毒性の評価指標となる可能 性が考えられ、現在他の化学物質にも応用できるか検討中である。

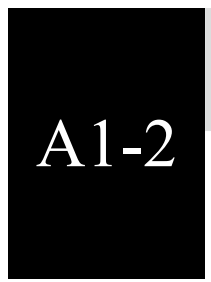

\section{一酸化窒素合成酵素系の遺伝子欠損はマウス中大脳動脈閉塞後 の脳梗塞サイズを著明に縮小させる}

○筒井正人 ${ }^{1}$ 、久保田陽秋 ${ }^{2}$ 、野口克彦 ${ }^{1}$ 、松崎俊博 ${ }^{1}$ 、坂梨まゆ子 ${ }^{1}$ 、喜名美香 ${ }^{1} 、$

内田太郎 ${ }^{1} 、$ 仲宗根淳子 ${ }^{1}$ 、要 匡 $^{3}$ 、須加原一博 ${ }^{1}$ 垣花 学 $^{1}$

(琉球大院・医・薬理、麻醉科、先進ゲノム検查医学)

【背景と目的】脳梗塞は日本人の主要な死因の一つである。脳梗塞の病態では、3種類全ての一酸化窒素 合成酵素（NOSs）アイソフォームが発現している。これまでに、脳梗塞におけるNOSs系の役割が、非 選択的NOSs阻害薬を用いて薬理学的に検討されてきた。しかし、非選択的NOSs阻害薬は中大脳動脈閉 塞モデルにおける脳梗塞サイズを増大させたとする報告と、逆に縮小させたとする報告があり、結果が 一致していない。この不一致は、非選択的NOSs阻害薬の非特異性に起因すると考えられている。本研究 では、この点を、NOSs系完全欠損マウスを用いて検討した。

【方法と結果】NOSs系完全欠損マウスを新たに作製し実験に使用した。中大脳動脈閉塞後の脳梗塞サイ ズは、野生型マウスに比してNOSs系完全欠損マウスで著明に縮小していた。さらに、神経学的障害の程 度は野生型マウスに比してNOSs系完全欠損マウスで有意に軽く、生存率はNOSs系完全欠損マウスで有 意に高かった。

【結論】以上より、NOSs系は脳梗塞において傷害的な役割を果たしていることが示唆された。この結果 より、NOSs系の抑制が脳梗塞の新しい治療法になりうる可能性が考えられた 


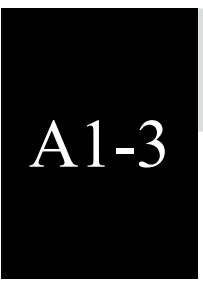

\section{プロサイモシン $\alpha$ の脳血管保護作用の検討}

○前田詩織、近藤秀春、佐々木恵太、植田弘師

(長崎大院・医歯薬・創薬薬理)

プロサイモシン $\alpha(\mathrm{ProT} \alpha)$ は、虚血時に遊離されネクローシス性の細胞死を抑制することで神経細胞 保護作用を示す内在性タンパク質である。近年当研究室では、脳梗塞モデルマウスにおいて、ProTaが 組織・機能的に障害を抑制することに加え、血管障害の保護作用を有することを見出している。現在脳 梗塞治療において用いられている血栓溶解剤tPAは、脳梗塞後期での使用は脳内出血のリスクが高まる ことから、ガイドラインにおいてその使用は発症後4.5時間以内に制限されている。そこで本研究では、 ProTaの血管保護効果に着目し、脳虚血後の血液脳関門の障害やtPA誘発性脳出血に対するProTaの保護効 果の検討を行った。

実験にはC57/BLマウスを用いて、一過性中大脳動脈閉塞(tMCAO)処置を行った。MCAO開始2時間後 にProTaを尾静脈投与 (i.v.) し、24時間後に脳血管を染色したところ、ProTa投与群はvehicle投与群に比べ、 長い血管が確認された。また、血管透過性の指標として内在性IgGやEvans blueの血管外漏出に招ける定 性・定量解析を行ったところ、ProTa投与群では血管外漏出が抑制され、血管透過性が改善したことが示

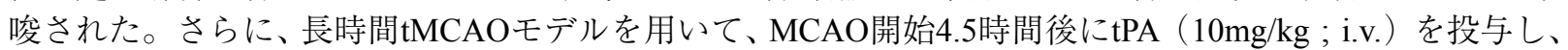
出血痕の評価を行ったところ、tPAとProTaを併用することにより脳出血が劇的に改善された。

本研究より、ProTaは神経保護作用のみならず、強力な血管保護作用も有することが検証された。神経 保護機能と血管保護機能は作用点が異なると考えられ、今後はこの血管保護作用のメカニズムとして、 ProTaが作用する細胞種や分子を解明していく。

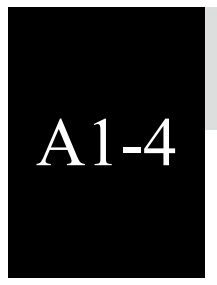

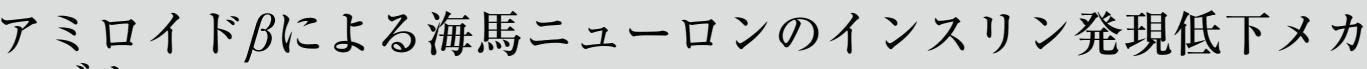 ニズム}

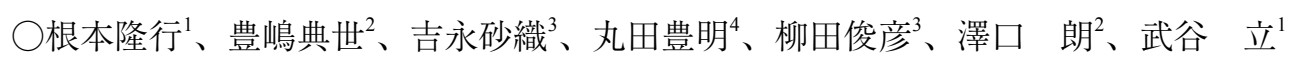
(宮崎大·医・機能制御・薬理、“解剖・超微形態科学、看護、“宮崎大病院・麻酔科)

【目的】脳内のインスリンは神経回路網の形成・維持・修復を促し、代謝障害や炎症反応に起因されるさ まざまなストレスから神経を保護している。近年、アミロイド㠜集による老人班を起因とするアルツハ イマー病患者脳で、インスリン遺伝子発現低下やインスリン抵抗性様の病態生理学変化が確認された。 さらに、それらの病理学的変化がアルツハイマー病を著しく加速させるという実験結果が相次いで報告 された。しかしながら、アルツハイマー病態時に見られる、脳由来インスリン発現低下のメカニズムは 未だ解明されていない。そこで私たちは、アミロイド腃用いてアルツハイマー様病態モデル細胞を作成 し、アルツハイマー病態時の脳由来インスリン発現メカニズムを解析した。

【方法】培養海馬ニューロンにアミロイド $\beta$ を添加し、脳由来インスリンの発現動向について解析を行っ た。蛋白質発現解析とリン酸化解析は、ウェスタンブロットおよび免疫染色法を用いた。 $\mathrm{pH}$ 感受性蛍光 蛋白質 pHluorin（pH 7.4 : 細胞外で GFP 発光、pH 5.0 : 分泌小胞内で消光）をインスリンに付加し、そ のinsulin-pHluorin 蛋白質を海馬ニューロンに発現させることにより、インスリンの細胞外 (pH 7.4) へ の分泌を可視化した。

【結果】 Insulin-pHluorin 蛋白質を発現させた海馬ニューロンを $50 \mathrm{mM} \mathrm{KCl}$ で刺激すると、発光（インス リン分泌）が見られた。その発光度合いはアミロイド $\beta$ を添加した細胞で低下していた。さらにアミロイ ド $\beta$ はプロインスリン（インスリン前駆体）の蛋白質発現量を減少させた。一方、細胞をリチウム（GSK-3 活性抑制薬)、siGSK-3 $\beta$ (GSK-3 $\beta$ ノックダウン) で事前処置すると、アミロイド $\beta$ アよるプロインスリン 発現量減少を阻止することができた。

【考察】アルツハイマー病因子であるアミロイド $\beta$ GSK-3 $\beta$ を過剩に活性化することによりプロインスリ ン量を減少させる。さらにアミロイド $\beta$ はnsulin-pHluorin蛋白質の蛍光度合いを低下させることから、イ

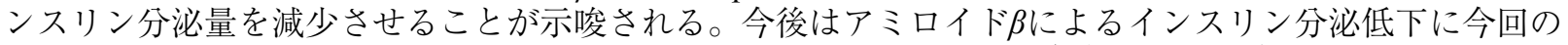
プロインスリン発現量減少が関与しているのか、あるいは別の機序が存在するのか検討していきたい。 


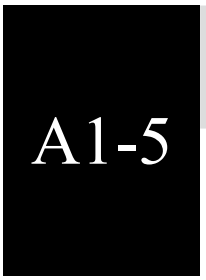

\section{幼若期ACTH反復投与ラットの行動学的特性}

○山口 拓 ${ }^{1} 、$ 吉岡充弘 ${ }^{2} 、$ 山本経之 ${ }^{1}$

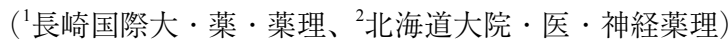

【目的】本研究では、HPA axisの中心的なストレスホルモンの一つであるACTHの幼若期反復投与処置に よる「幼若期薬理学的ストレス負荷ラット」を作製し、幼若期に受けたストレスが成長後の認知・情動 行動表出に及ぼす影響について検討した。

【実験方法】離乳した幼若期（3週齢）のWistar系雄性ラットに、ACTHの活性アナログである酢酸テトラ コサクチド (30あるいは100 $\mu \mathrm{g} / \mathrm{rat} / \mathrm{day})$ を5日間反復皮下投与した (ACTH群)。対照群として生理食塩 水を同様に投与した。ACTHの効果を検証するために血漿中コルチコステロン（CS）濃度を酵素免疫測 定法によって測定した。発達期（6週龃）拉よび成熟期（10週齢）において、行動学的検討として (1)自 発的交替行動試験（Y-maze試験）、(2)オープンフィールド (OF) 試験、(3)高架式十字迷路 (EPM) 試験、 (4)文脈的恐怖条件付け（CFC）試験（10週齢のみ）を実施し、本モデルラットの行動学的特性を評価した。 【実験結果】3週齢時におけるACTH $100 \mu \mathrm{g}$ の単回投与は、対照群と比較して血漿中CS濃度を有意に増加 させた。その後のACTHの反復投与5日目では投与初日と比較して血漿中CS濃度は約2倍まで上昇した。 この幼若期ACTH反復投与ラットの成長後の行動変容について、(1) Y-maze試験：10週齢時のACTH群に のみ自発的交替行動率の有意な減少が認められた。(2) OF試験：6および10週齢時とも ACTH $100 \mu \mathrm{g}$ 投与 群では30分間の総移所運動量が有意に減少した。(3) EPM試験：10週齢時にのみACTH $100 \mu \mathrm{g}$ 投与群にお けるopen armの滞在時間が有意に減少した。(4) CFC試験：10週齢時における恐怖条件付け24時間後のす くみ行動の発現率は、ACTH群と対照群との間に差はなかった。

【考察および結論】ACTH群の成熟期では、Y-maze試験から短期記憶障害、EPM試験から不安様行動を発 現している可能性が考えられた。いずれの場合も発達期では変化がなかったことから、幼若期のACTH によるHPA axisの擾乱は、成長後に認知・情動行動障害を発現すること、またその行動異常の発現には 時期特異性があることが明らかとなった。

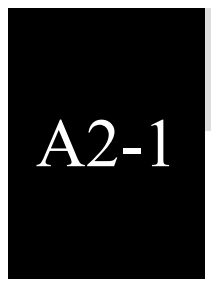

\section{有痛性神経障害患者血清のマウスへの受動的移入による疼痛様} 行動の再現

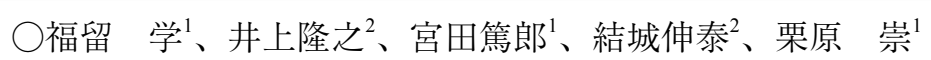

('鹿児島大院・医歯・生体情報薬理、シンガポール国立大・医)

有痛性神経障害は、小径感覚神経線維での障害が目立つ神経障害であり、その神経障害の原因の一つ として免疫介在性のものが多く存在すると考えられているが、未だエピトープや発症メカニズムが明ら かになっていないものがほとんどである。本研究では、免疫介在性が疑われる有痛性神経障害を有する 患者血清をマウスへ受動的移入することにより、疼痛様行動の再現が可能かどうか検討した。

実験動物として、6-8週齢の雄性ddY系マウスを用いた。血清（患者血清あるいは正常対照血清）は、 くも膜下腔投与 $(5 \mu \mathrm{l})$ 、あるいは血清 $(5 \mu \mathrm{l})$ を吸収させた組織吸収性ガーゼを坐骨神経に隣接させて 留置することで移入させた。疼痛行動学的検討は、von Frey刺激毛を用いた $50 \%$ 閾值測定、㧍よび足底 熱刺激装置を用いた逃避反射潜時測定で評価した。

今回検討を行った患者血清は、中核的臨床症状としてpin prick刺激による顕著な痛覚過敏を踵部に持 つ女性患者からのものである(Wilder-Smith, E.P. (2006) J. Peripher. Nerv. Syst., 11:172-173)。本患者血清を 髄腔内投与すると、投与翌日から約 1 か月間持続する顕著な機械的過敏現象を誘発したが、熱性痛覚過敏 現象は生じなかった。また坐骨神経への投与でも、2週間持続する機械的過敏現象を誘発した。一方、検 討した3種の正常対照血清では、いずれの投与方法でも有意な機械的過敏現象を誘発しなかった。

免疫介在性が疑われた有痛性神経障害患者の血清をマウスに受動的移入を行うことで、患者の中核的 臨床症状である機械的痛覚過敏現象を再現することができたことから、本患者の疼痛症状は、自己抗体 が関連している自己免疫応答によるものであることが示唆された。また、受動的血清移入疼痛モデルは、 痛みを伴う自己免疫性神経障害発症メカニズムおよび治療法の検討に有用であることが期待される。 


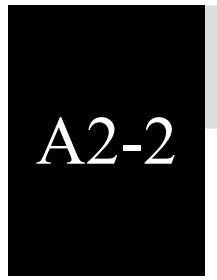

\section{侵害刺激時における春䯣アストロサイトシグナリングのin vivo imaging}

○松田烈士、齊藤秀俊、津田 誠* 井上和秀

(九州大院・薬・薬理、*ライフイノベーション)

グリア細胞の一種であるアストロサイトは神経回路網の支持細胞としてだけではなく、シナプス機能 の調節や血液脳関門の形成など多様な役割を持っている。アストロサイトは電気的に非興奮性の細胞で あるが、代わりに細胞内 $\mathrm{Ca}^{2+}$ 濃度変化が細胞内シグナルの活性化指標として用いられており、活性化に 応じて様々なグリア伝達物質を放出することが知られている。近年、2光子励起顕微鏡の登場によりアス トロサイトの形態や機能を個体レベルでイメージングすることが可能になり、さらに神経活動に応じた 脳内アストロサイトの $\mathrm{Ca}^{2+}$ 応答も可視化できるようになっている。しかしながら、脊髄後角のin vivo イ メージング技術は未だ不十分であり、感覚伝達時における春髄後角アストロサイトの活動は殆ど解明さ れていない。そこで我々はマウスを用いたin vivo脊髄後角 $\mathrm{Ca}^{2+}$ イメージング法を確立し、感覚伝達時にお ける脊髄後角アストロサイトの $\mathrm{Ca}^{2+}$ シグナリングの解明を試みた。ウイルスベクターを利用して脊䯣後 角アストロサイト選択的にGCaMPを発現させたマウスを作成し、後肢への様々な刺激に対する脊髄後角 アストロサイト $\mathrm{Ca}^{2+}$ 応答を 2 光子励起顕微鏡にてイメージングした。その結果、侵害刺激を与えた際に脊 髄後角アストロサイトで $\mathrm{Ca}^{2+}$ 応答が引き起こされることを見出した。さらにこの反応はレシニフェラト キシンを用いたTRPV1陽性神経線維の脱落により消失した。このことから、疼痛伝達時の脊髄アストロ サイトのCa ${ }^{2+}$ 上昇はTRPV1陽性神経線維を介して引き起こされていることが明らかになった。本研究の 結果は、アストロサイトが脊髄レベルで侵害刺激を受容して活性化することを示し、さらには脊髄アス トロサイトが痛覚伝達シグナルに対して脊髄レベルでの調節機能を有する可能性を示唆するものである。

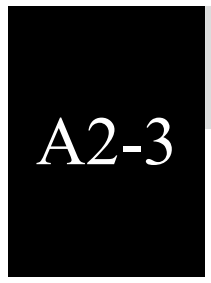

\section{ミクログリアの形態変化におけるカテプシンSの関与}

○高山扶美子、林 良憲、武 洲、中西 博

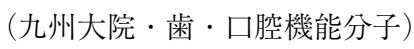

最近、私たちはミクログリアが独自の分子時計をもち、脳内のミクログリア特異的分子であるカテプ シン Sの発現を制御することでスパイン密度ならびにシナプス強度の日内変化に関与することを報告した (林ほか, SciRep, 2013)。そこで今回は、カテプシンS発現の日内変化のミクログリアならびにニューロ ン機能に及ぼす影響についてさらに詳細な解析を行った。

明期（ZT2）および暗期（ZT14）にDBA/2マウス大脳皮質よりスライス標本を作製し、ミクログリア 細胞内染色ならびに長期増強現象（LTP）測定を行った。その結果、ミクログリア突起の総延長ならび に分岐数は暗期の方が明期よりも有意に大きく、より複雑な突起構造を示した。LTP増強率も暗期に有 意に増加した。さらにIba1-EGFPマウスを用い二光子顕微鏡下でミクログリア突起の伸縮速度を計測した 結果、暗期の方が明期よりも有意に速い速度で伸縮していることが明らかとなった。一方、カテプシン $\mathrm{S}$ 欠損マウスではミクログリアの形態ならびにLTP増強率の日内変化は認めなかった。またカテプシンS阻 害剤はATPにより誘導されるミクログリア突起の伸展を抑制した。以上の結果より、カテプシンSの発現 量は活動期（暗期）の初期に増大に達し、非活動期（明期）に扔けるミクログリア突起の退縮、スパイ ン密度の減少ならびにシナプス可塑性の低下に関与することが示唆された。 


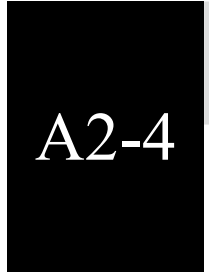

\section{新規脳組織切片培養モデルを用いた $\mathrm{Na}^{+} / \mathrm{K}^{+}-\mathrm{ATPase}$ 阻害による 脳血管構造傷害機序の解析}

$\bigcirc$ 倉内祐樹 ${ }^{1,2}$ 、久恒昭哲 ${ }^{1,2}$ 、関 貴弘 $^{3}$ 、香月博志 ${ }^{3}$

(1熊本大院・先導機構、2熊本大・リーディング大学院HIGOプログラム、

熊本大院·生命·薬物活性)

【背景・目的】双極性障害は躁症状とうつ症状を繰り返す気分障害であり、 $\mathrm{Na}^{+} / \mathrm{K}^{+}$-ATPaseの活性低下が 病態発症に関与する事が示唆されている。近年、患者の特定の脳領域の血流量が減少している事も報告 されているが、脳血管構造変化が病態発症に関与するかは明らかではない。本研究では、脳血管構造変 化を定量的に評価する新規in vitroモデルを構築し、ウアバイン処置による薬理学的な $\mathrm{Na}^{+} / \mathrm{K}^{+}-\mathrm{ATPase}$ 阻害 時の脳血管構造変化について解析した。

【方法】生後2-3日齢のWistar系ラットより全脳を摘出し、前頭前野領域を含む厚さ350 $\mu \mathrm{m}$ の大脳皮質冠状 切片を作製し、多孔質膜上で5日間培養した。ウアバイン処置による薬理学的な $\mathrm{Na}^{+} / \mathrm{K}^{+}-\mathrm{ATPase}$ 阻害の後、 抗RECA-1抗体および抗PDGFR- $\beta$ 抗体を用いた免疫組織化学により血管内皮細胞およびペリサイトをそれ ぞれ検出し、蛍光顕微鏡（BZ-9000, KEYENCE）によるz-stack画像取得後、ImageJ Softwareによる解析 を行った。

【結果・考察】ウアバイン $(1-10 \mu \mathrm{M})$ はPDGFR- $\beta$ 陽性面積には影響せずRECA-1陽性面積のみを有意に減 少させた。また、ウアバインは培養組織切片中のBcl-2タンパク質発現量およびGSK $3 \beta$ リン酸化レベルを 顕著に減少させ、この効果は双極性障害治療薬であるリチウム (1-5 mM) の前処置により抑制された。さ らに、ウアバインよる血管内皮細胞傷害はIP ${ }_{3}$ 受容体阻害薬であるXestospongin $\mathrm{C}(4 \mu \mathrm{M})$ により有意に抑 制されたが、 $\mathrm{Na}^{+} / \mathrm{Ca}^{2+}$ exchanger阻害薬であるSEA0400 $(30 \mu \mathrm{M})$ の前処置では抑制されなかった。以上の 結果から、双極性障害発症には血管内皮細胞の傷害による脳血管構造の破綻が関与すること、さらに血 管内皮細胞傷害にはIP 3 受容体を介した小胞体から細胞質へのCa ${ }^{2+}$ 流出増加が関与する事が示唆された。

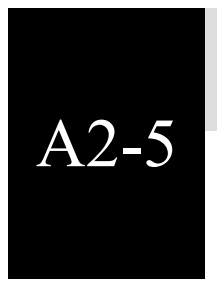

\section{DNA二重鎖切断修復酵素の特異的リン酸化抑制による腫瘍発 生機構の解明}

○松永慎司 ${ }^{1} 、$ Shichuan Zhang ${ }^{2}$ 、今西正樹 ${ }^{1}$ 、Panaghiota Tsunapi ${ }^{1}$ 冨田修平 ${ }^{1}$ 、

Benjamin Chen $^{2}$

( ${ }^{1}$ 鳥取大 · 医 · 病態解析医学 ·分子薬理、 ${ }^{2}$ University of Texas Southwestern Medical Center)

DNA損傷の中でもDNA二重鎖切断は最も危険なDNA損傷型である。この二重鎖切断の修復過程には 相補鎖を鋳型として修復を行う相同末端結合（HR）と相補鎖を必要としない非相同末端結合（NHEJ） が存在する。我々はこれまでにNHEJ修復経路にいて主要な役割を果たすDNA-dependent protein kinase catalytic subunit（DNA-PKcs）の機能について研究を行ってきた。その中でDNA-PKcsのリン酸化が正常 な細胞周期、特に細胞分裂期においては必要なシグナルであることを示してきた。このことはDNA-PKcs の機能のひとつとしてゲノム安定性に関わっていると考えられた。さらに、DNA-PKcs遺伝子のリン酸化 部位変異を含む体細胞変異は乳癌患者において生じた例が報告されている。このことはヒトで生じる遺 伝子変異であることを示している。我々はDNA-PKcsリン酸化部位変異マウスモデルを作製し、このマウ スにより生体内でのDNA-PKcsのリン酸化の機能的役割について解析を行った。

作製したDNA-PKcsリン酸化部位変異マウスは生後間もなく先天性骨髄不全により死亡するDNA-PKcs 欠失型であるSCIDマウスでは認められない重篤な表現系を示した。そのため野生型同腹子から骨髄移植 を施行することで骨髄不全の救援を行った。しかしながら、これらのマウスは生後 1 年程度経過するとほ ぼすべてのマウスで腫瘍を発症した。これらの事象はDNA-PKcs欠失型よりも高い腫瘍発症頻度であっ た。そこで、我々はこの腫瘍発症機構を明らかにするために検討を行ったのでここに報告する。 


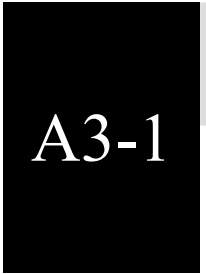

\section{ミクログリアに発現するP2X4受容体を標的とした神経障害性 疼痛治療薬の探索に向けたエコファーマの取り組み}

○山下智大 ${ }^{1}$ 、張 佳明 $^{1}$ 、津田 誠 ${ }^{1,2}$ 、齊藤秀俊 ${ }^{1}$ 井上和秀 ${ }^{1}$

(九州大院・薬・ ${ }^{1}$ 薬理、泉ライフイノベーション)

ATP受容体は生体において広く発現しており、さまざまな生理現象や病態に関与することが知られて いる。我々はこれまでに春髄ミクログリアに発現するP2X4受容体 (イオンチャネル型ATP受容体) を介 したシグナルが、神経障害性疼痛の発症維持に重要な役割を担うことを明らかにした。神経障害性疼痛 とは、癌や糖尿病、带状疮疹などによる末梢神経の損傷や変性により発症し、本来痛みとして感じない 触刺激を激烈な痛みと感じてしまうアロディニアを主症状とする難治性疼痛である。しかし現在に至る まで、神経障害性疼痛に対する十分な治療法は確立されていないため、患者さんへの治療薬の早期提供 が強く望まれる。そこで本研究では、既承認医薬品から新しい薬理作用を見出すことで, より早く臨床 で使用できるようにする研究「エコファーマ」を目指して、P2X4受容体拮抗薬の探索を行った。東京大 学創薬オープンイノベーションセンターから提供された1979個の既知化合物ライブラリーおよびラット P2X4受容体安定発現細胞株を利用して、カルシウムイメージング法にてスクリーニングを行った。その 結果、抗うつ薬のデュロキセチンがラットP2X4受容体を強力に遮断することを見出した。また、デュロ キセチンは濃度依存的にラットP2X4受容体およびヒトP2X4受容体介在性カルシウム応答を抑制した。そ して、ミクログリアの細胞株であるC8-B4細胞に発現するATP受容体に対してデュロキセチンの効果を検 証したところ、P2X4受容体への特異的な機能阻害効果が認められた。さらに、神経障害性疼痛モデルラッ トにデュロキセチンを髄腔内投与することで、アロディニア症状の顕著な回復が認められた。以上の結 果より、デュロキセチンはP2X4受容体を標的とした有効な神経障害性疼痛治療薬となる可能性が考えら れる。

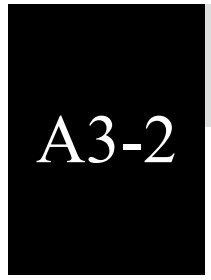

\section{pH感受性リガンドによる受容体インターナリゼーションアッ セイ法の確立及び同法を用いた各医療用麻薬の解析}

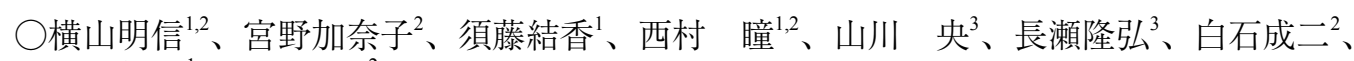
樋上賀一 ${ }^{1}$ 、上園保仁 ${ }^{2}$

('東京理科大院・薬・分子病理・代謝、年国立がん研・がん患者病態生理、 ${ }^{3}$ かずさDNA研)

【背景・目的】morphine, fentanyl, oxycodoneは医療用麻薬としてがん性疼痛に対し使用される。これらの 医療用麻薬は生体において $\mu, \delta, \kappa$ オピオイド受容体 $(\mu \mathrm{OR}, \delta \mathrm{OR}, \kappa \mathrm{OR})$ を介して鎮痛作用を発揮している。 $\mu \mathrm{OR}$ 介したシグナル伝達が鎮痛作用に重要であると考えられている一方で、急性期における鎮痛耐性 には $\mu \mathrm{OR}$ のインターナリゼーションが関与していると考えられている。従来のインターナリゼーション 解析は蛍光蛋白融合受容体を利用していたが、細胞膜上の受容体とインターナリゼーション後の細胞内 受容体の区別が困難であった。そこで本研究では新規 $\mathrm{pH}$ 感受性リガンドを用いて $\mu \mathrm{OR}$ インターナリゼー ションを客観的に定量化することを目的とした。

【方法】HaloTag ${ }^{\circledR}$ をORのN末端に融合し、Human Embryonic Kidney 293 (HEK293) 細胞に安定発現させた。 この細胞にHaloTag ${ }^{\circledR} に$ 特異的に結合し、pHの低下に伴い赤色蛍光強度が増大する細胞膜非透過性かつ $\mathrm{pH}$ 感受性のHaloTag ${ }^{\circledR}$ Ligandを 15 分間 $37^{\circ} \mathrm{C}$ で反応させた。その後、共焦点レーザー顕微鏡を用いて $\mu \mathrm{OR}$ 作動 薬であるDAMGO $(1 \mu \mathrm{M})$ 、morphine $(10 \mu \mathrm{M})$ 、fentanyl $(100 \mathrm{nM})$ 、oxycodone $(10 \mu \mathrm{M})$ をそれぞれ滴下し、 赤色蛍光強度を経時的に観察した。取得した画像データはCellomic ${ }^{\mathrm{TM}}$ ArrayScan $^{\circledR} \mathrm{V}^{\mathrm{TI}}$ Systemにより解析 し、赤色スポット数をインターナリゼーションした受容体として定量化した。

【結果・考察】 morphine, oxycodoneは $\mu \mathrm{OR}$ インターナリゼーションをほとんど引き起こさなかった。一方、 DAMGO, fentanylは顕著な $\mu \mathrm{OR}$ インターナリゼーションを引き起こすことを客観的定量法により明らか にした。本研究ではインターナリゼーションにより $\mathrm{pH}$ の低い小胞体内に取り込まれ、赤色蛍光を生じる HaloTag ${ }^{\circledR}$ Ligandの特徵を活かし、インターナリゼーションした受容体のみを可視化及び定量化すること を可能にした。同法により各医療用麻薬が急性耐性に関与する $\mu \mathrm{OR}$ インターナリゼーションに関してそ れぞれ異なる性質を有していることが客観的に示された。 


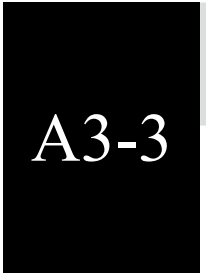

\section{アディポネクチン受容体 1 を介した 迅速簡便な受容体シグナルアッセイ法確立の試み}

○西村 瞳1,2、宮野加奈子 ${ }^{2} 、 山 川 ~$ 央 $^{3} 、$ 横山明信 ${ }^{1,2}$ 、須藤結香 ${ }^{1}$ 白石成二 2 、樋上賀一 ${ }^{1} 、$

長瀬隆弘 ${ }^{3} 、$ 上園保仁 ${ }^{3}$

('東京理科大院・薬・分子病理・代謝、同立がん研・がん患者病態生理、 ${ }^{3}$ かずさDNA研)

【背景・目的】アデイポネクチンは脂肪細胞で産生、分泌され、脂肪酸燃焼、糖新生・炎症性サイトカイ ンの産生および活性を抑制する。その血中動態は肥満や生活習慣病と逆相関することから、アディポネ クチン受容体作動薬は新規抗生活習慣病薬として期待されている。アデイポネクチン受容体 (AdipoR1 · R2）の活性は通常AMP-activated protein kinase（AMPK）のリン酸化を指標に測定されるが、迅速かつ簡 便ではない。そのため、新規アゴニストのスクリーニング等にはより迅速かつ簡便なアッセイ法が望ま

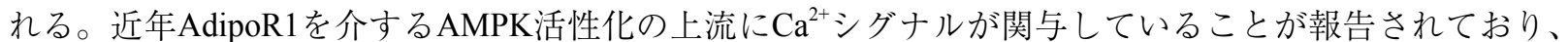
受容体活性化による細胞内Ca ${ }^{2+}$ 濃度を測定できれば、より簡便なアッセイ法となることが期待される。

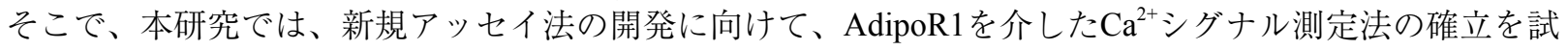
みた。

【方法】AdipoR1安定発現細胞はHaloTag 良融合させたヒトAdipoR1クローンをHEK293細胞に発現させ、 G418による薬剤セレクションすることにより作製した。AdipoR1の発現は、HaloTag ${ }^{\circledR}$ と特異的かつ不可

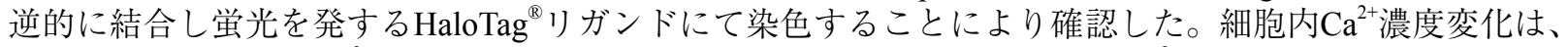

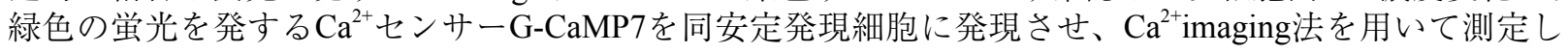
た。

【結果・考察】HaloTag 融合AdipoR1をHEK293細胞に安定発現させたところ、細胞膜上にAdipoR1が発現 した。さらにこのAdipoR1安定発現細胞はアゴニスト濃度依存的に細胞内 $\mathrm{Ca}^{2+}$ 濃度を上昇させた。した がって、本研究により機能的なHaloTag ${ }^{\circledR}$ 融合AdipoR1安定発現HEK293細胞を樹立し、新規アデイポネク チン受容体作動薬の迅速かつ簡便なスクリーニング系としてG-CaMP7を用いた細胞内Ca $\mathrm{Ca}^{2+}$ 濃度測定法が 有用であることが示唆された。現在、アッセイ条件をさらに検討しスクリーニング法の最適化を試みて いる。

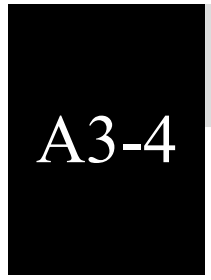

\section{下垂体アデニル酸シクラーゼ活性化ポリペプチドによる脳内グ リコーゲン代謝の活性化〜培養アストロサイトを用いた研究〜}

○神戸悠輝、宮田篤郎

（鹿児島大院・医歯・生体情報薬理）

脳内でグルコースはグリコーゲンとしてアストロサイトに貯蔵され、神経活動依存的に分解され、生 成したエネルギー担体をニューロンが利用する。この神経活動依存的な脳内グリコーゲン代謝の活性化 が高次脳機能の発現に必須であることが報告されている。一方で、これまでにノルアドレナリンや血管 作動性腸管ぺプチド（VIP）がグリコーゲン代謝を活性化することが知られている。しかし、いずれの 神経伝達物質が脳内グリコーゲン代謝の調節に重要であるか詳細には解明されていない。本研究では、 VIPと同じセクレチン-グルカゴンファミリーに属する下垂体アデニル酸シクラーゼ活性化ポリペプチド (PACAP) に注目し、培養アストロサイトにおけるグリコーゲン分解活性と、グリコーゲンの分解に関与 する受容体を薬理学的に解析した。

初代培養アストロサイトに300 fMから $10 \mathrm{nM}$ のPACAPと10 pMから $1 \mathrm{pM}$ のIPを曝露し、1時間後にお けるグリコーゲン含量をグリコーゲン定量キット (BioVision) で測定し、グリコーゲン分解活性のEC $\mathrm{E}_{50}$ を算出すると、PACAPは0.008 nM、VIPは0.43 nMであった。興味深いことにPACAPのグリコーゲン分解 活性は、ノルアドレナリン $\left(\mathrm{EC}_{50}=20 \mathrm{nM}\right)$ やVIPと比較して顕著に高かった。また、PACAPはPACAP特 異的受容体PAC1と、VIPと共にアゴニストとして作用するVPAC1/2に作用し機能を発現する。培養アス トロサイトにPAC1特異的なアゴニストであるマキサディランを曝露すると、弱いグリコーゲン分解の活 性化が引き起こされ、PAC1特異的なアンタゴニストであるMax.d.4とVPAC1/2のアンタゴニストである VIP[6-28]のPACAPのグリコーゲン分解の活性化に及ぼす効果を観察すると、2つのアンタゴニストを同 時に曝露した場合にのみ有意な阻害効果が観察された。

以上の結果から、培養アストロサイトに挄いてPACAPはノルアドレナリンやVIPと比較してグリコーゲ ン代謝の活性化能力が強く、このグリコーゲン分解の活性化にはPAC1 と VPAC $1 / 2$ のすべての受容体が関 与することが示唆された。 


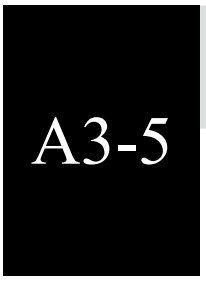

\section{GRK5の生物時計への関与}

○梶木恒平、仲矢道雄、藤野美香、長坂明臣、黒瀬 等

(九州大院・薬・薬効安全)

生物には体内時計が備わっており、様々な生体機能や行動は約一日周期で変動している。この変動は 概日リズムと呼ばれ、時計タンパク質の発現量や細胞内局在により調節されている。時計タンパク質の リン酸化は、時計タンパク質を分解や核内移行に導くことから、概日リズムの制御に重要な役割を持つ。 しかし時計タンパク質のリン酸化に関しては、未だ不明な点が多い。

我々の研究室では、GRK5を介したシグナル伝達の研究を行ってきた。GRKはGタンパク質共役型受容 体（GPCR）をリン酸化し、GPCRを脱感作へと導くキナーゼとして同定された。しかし近年、GRKは様々 なタンパク質をリン酸化することが報告され、GPCRが脱感作以外の生理的機能を有することが明らかに なりつつある。我々はGRK5研究の過程で偶然にもGRK5が生物時計の分子メカニズムに関与する可能性 を見出した。

そこでまず、GRK5と生物時計の分子メカニズムとの接点を調べるためにGRK5と13種の時計タンパ ク質との相互作用を免疫沈降法によって調べた。その結果、Period (Per) 1,2,3とCryptochrome (Cry) 1,2が GRK5 と相互作用することが明らかとなった。このPerやCryは生体時計機構の中枢を構成する因子であ り、自分自身の転写活性を抑制することが知られている。そこで、GRK5がPerと複合体を形成する事に よってPerの転写にどのような影響を及ぼすのかについて、Per1::Lucを用いたLuciferase assayにより検討 した。その結果、GRK5がPer1のpromoter活性を強く抑制することを見出した。この結果から、GRK5が Perの局在を変化させていると考えられた。そこで、HEK293細胞にGRK5 とPer2を共発現させ、免疫染色 法によってPer2の局在を観察したところ、GRK5を発現させると、Per2の核内移行が促進されることが明 らかとなった。以上の結果より、GRK5はPerの核内移行を促進することで、生物時計の分子メカニズム に関与する可能性が示された。

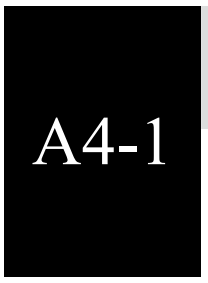

\section{イヌの乳腺腫㵿細胞におけるPP2A阻害因子SETの役割の解明}

○早瀬寛志、兒井達哉、加計 悟、大浜 剛、佐藤晃一

(山口大 ·共同獣医 · 獣医薬理)

【背景・目的】 Protein Phosphatase 2A（PP2A）は進化的に保存されたSer/Thrタンパク質脱リン酸化酵素 であり、がん抑制因子として働くことが知られている。内在性のPP2A阻害タンパク質の一つであるSET は、PP2Aと複合体を形成することでその活性を阻害する。近年、ヒトの乳腺腫瘍においてSETが腫瘍の 成長を促進していることが報告され、がんの悪性化に抒ける重要性が示唆されているが、イ又の乳腺腫 瘍に扮けるSETの役割については未解明のままである。そこで本研究では、イヌの乳腺腫瘍細胞株を用 いて、比較生物学的観点からSETの役割について解析を行なった。

【結果・考察】7種類のイヌ乳腺腫瘍細胞株についてSETタンパク質の発現を確認したところ、いずれの 細胞株でもその発現が認められた。原発巣由来CIP-p細胞执よび転移巣由来CIP-m細胞について、SETを 標的としたshRNAを安定的に発現させた細胞株を作成した。CIP-pにおいては、SET発現抑制によってド キソルビシンに対する感受性が上昇したが、細胞増殖能や足場非依存性のコロニー形成能、遊走能およ び放射線照射に対する感受性には影響が認められなかった。一方CIP-mにおいては、SET発現の低下は細 胞増殖能および足場非依存性のコロニー形成能を低下させ、ドキソルビシンとカルボプラチンに対する 感受性が上昇した。一方、細胞遊走能および放射線照射に対する感受性については、CIP-m細胞におい ても影響が認められなかった。以上の結果から、ヒトの乳腺腫瘍と同様にイ又乳腺腫瘍の悪性化におい ても、SETが重要な役割を果たしていることが明らかになった。さらに、SETは転移した乳腺腫瘍に対し て治療標的となる可能性が示唆された。 


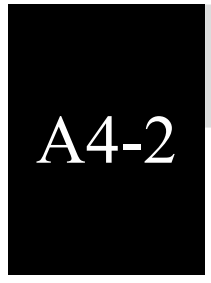

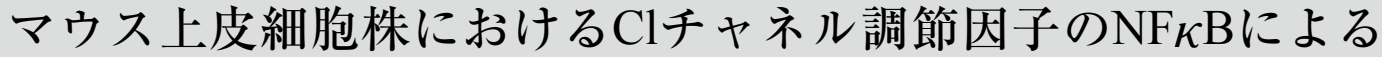
転写制御

○廣松 亮、八田光世 ${ }^{2} 、$ 田中喜太郎 ${ }^{2}$ 坂上竜資、山﨑 純 $^{2}$

(福岡歯大 $\cdot{ }^{1}$ 口腔治療・歯周病学、 ${ }^{2}$ 細胞分子生物 $\cdot$ 分子生物 $\cdot$ 分子機能制御 $)$

【背景・目的】CLCAはカルシウム活性化クロライドチャネルの調節因子として位置づけられている。近 年、CLCAのアイソフォームがケラチノサイトの分化に関与しているとの報告が存在するが、CLCA遺 伝子の発現制御については不明な点が多く残る。本研究はマウスケラチノサイト株Pam212を用いて、 CLCA2遺伝子の転写制御メカニズムの解明を目的とした。

【結果】培養液中のカルシウム濃度を $0.05 \mathrm{mM} ら 1.0 \mathrm{mM}$ 一上昇させた場合、分化マーカーである keratin1とともに、mCLCA2のmRNAレベルが増加した。しかしながら mCLCA1と mCLCA5には、ほとん ど変化は認められなかった。ルシフェラーゼアッセイの結果では、mCLCA2の近位プロモーター領域に おいて高い転写活性を認めた。また、NFkB結合配列の変異やsiRNAを用いたノックダウンによって転 写活性は大幅に低下した。TNF- $\alpha$ およびcaffeic acid phenethyl ester (CAPE)ではそれぞれ転写活性の上昇、 低下を認めた。クロマチン免疫沈降と転写因子アッセイの結果では、mCLCA2のプロモーター領域に、 内在性に活性化したp65が結合することが明らかとなった。また、カルシウム濃度を上昇させたときの mCLCA2 mRNAレベルは、CAPEによって抑制された。

【結論】培養ケラチノサイトにおいて、mCLCA2 mRNA発現がbasalなNFkBの活性によって制御されてい ることが明らかとなった。

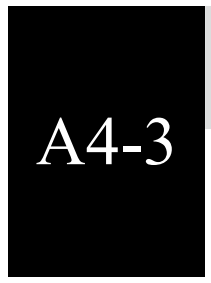

\section{Ikarisoside Aのカテコールアミン分泌及び生合成におよぼす影} 響

○李 暁佳、豊平由美子 ${ }^{1}$ 、堀下貴文 ${ }^{2}$ 、高橋圭太 ${ }^{1}$ 、張 晗 ${ }^{5}$ 吉永有香里 ${ }^{1}$ 、

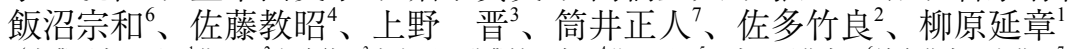

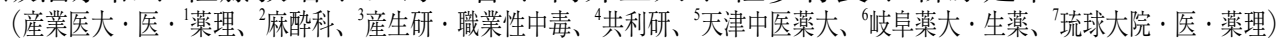

【目的】生薬「淫洋蕉」はインポテンツ、不妊症、半身不随、リウマチ、運動麻瘏、筋肉の病攣、疼痛等 に用いられている。淫洋舊（イカリソウ）の活性成分の一つであるIkarisoside Aはイソプレン側鎖のつい たフラボノイドで、RAW264.7 (マクロファージ) 細胞において抗炎症作用と破骨細胞分化抑制作用を示 すことが報告されている。しかしながらIkarisoside Aの神経系への作用に関しての報告はない。そこで本 研究では、交感神経のモデル実験系である副腎髄質細胞において、Ikarisoside Aがカテコールアミン（CA） の生合成、分泌に及ぼす影響について検討した。

【方法】ウシ副腎髄質細胞はコラゲナーゼ処理により分離、培養して、Ikarisoside A存在下でCA分泌、 ${ }^{22} \mathrm{Na}^{+}{ }^{45} \mathrm{Ca}^{2+}$ の流入、CA生合成、チロシン水酸化酵素活性を測定した。アフリカツメガエル卵母細胞に ニコチン性アセチルコリン（nACh）受容体（ $\alpha 3 \beta 4 ）$ を発現させ、リガンド誘発電流に対するIkarisoside Aの直接作用も検討した。

【結果】(1)Ikarisoside A (0.3-100 $\mu \mathrm{M})$ はnACh受容体刺激によって引き起こされるCA分泌や ${ }^{22} \mathrm{Na}^{+} 、{ }^{45} \mathrm{Ca}^{2+}$ 流入 を濃度依存的に抑制した。nACh受容体刺激によるCA分泌のIkarisoside Aによる抑制はAChの濃度を増加さ せても回復しなかった。(2)Ikarisoside A は電位依存性Na、Caチャネル刺激によって引き起こされるCA分 泌や ${ }^{22} \mathrm{Na}^{+} 、{ }^{45} \mathrm{Ca}^{2+}$ 流入には影響しなかった。(3)Ikarisoside A (1-100 $\left.\mu \mathrm{M}\right)$ はnACh受容体刺激によるCA生合成 及びチロシン水酸化酵素活性を濃度依存的に抑制した。(4)Ikarisoside A (0.1-10 $\mu \mathrm{M})$ はnACh受容体（ $\alpha 3 \beta 4 ）$ を発現させたアフリカツメガエル卵母細胞においてACh誘発電流を濃度依存的に抑制した。

【考察】Ikarisoside Aは副腎髄質細胞において、nACh受容体機能を抑制して、イオンチャンネルを介した $\mathrm{Na}^{+}$や $\mathrm{Ca}^{2+}$ 流入を阻害することにより、CA分泌及び生合成を抑制することが示唆された。 


\section{下垂体腺腫細胞GH3のプロラクチンおよび成長ホルモン分泌に 及ぼすリゾホスファチジルセリンの効果} A4-4

○井上和彦、竹ノ内里奈、國師恵美子、大和麻耶、神戸悠輝、宮田篤郎

（鹿児島大院・医歯・生体情報薬理）

\section{【研究背景と目的】}

リゾホスファチジルセリン（Lysophosphatidylserine: LysoPS）は、細胞膜構成脂質のホスファチジル セリンがホスホリパーゼによって加水分解されてできるリゾリン脂質である。LysoPSはマスト細胞の脱 顆粒、神経細胞の突起伸長、骨格筋でのグルコース輸送などに関与することが報告されている。我々は LysoPSをラットに静注投与すると血中プロラクチン濃度が増加することに着目し、下垂体ホルモン分泌 に及ぼすLysoPSの効果を調べた。

\section{【結果と考察】}

ラット下垂体腺腫細胞GH3は、プロラクチン（prolactin: PRL）および成長ホルモン（growth hormone: GH）分泌能を持つ細胞株である。GH3にLysoPSを添加すると、PRLとGHの分泌量が共に有意に増加した。 この反応はLysoPS特異的であり、他のリゾリン脂質（リゾホスファチジルエタノールアミン、リゾホス ファチジルコリン、リゾホスファチジン酸) では見られなかった。

プロテインキナーゼCの活性化はGH3のカルシウム感受性を上昇させ、プロラクチンの分泌を促進す ることが知られている。そこでGH3をプロテインキナーゼC阻害剂スタウロスポリンで前処理すると、 LysoPSによるPRLおよびGH分泌促進作用が抑制された。

また、LysoPSによるPRLおよびGH分泌促進作用は、百日咳毒素の前処理によって抑制された。LysoPS 受容体として同定されたG夕ンパク質共役型受容体GPR34はGiとカップリングするため、GH3における LysoPS とGPR34との相互作用を調べると、GH3ではGPR34が発現しており、siRNAでノックダウンする とLysoPSによるPRLおよびGH分泌促進作用が抑制された。

この結果から、LysoPSはGPR34に結合し、プロテインキナーゼCの活性化を介して細胞のカルシウム 感受性が増加することによって、GH3の分泌顆粒に蓄えられたPRLおよびGHの放出を促進すると考えら れた。

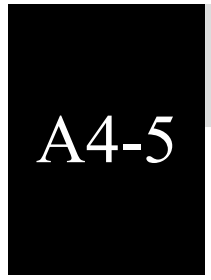

\section{マウス脺 $\beta$ 細胞においてアクチビン1B受容体シグナル活性はATP 感受性 $\mathrm{K}^{+}$チャネルの滅弱化を介してインスリン分泌を抑制する}

寺本憲功 ${ }^{1,2}$ 、野村政壽 ${ }^{3}$

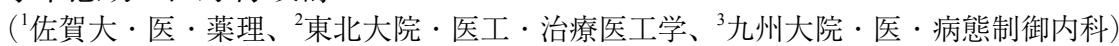

遺伝子欠損マウスを用いた我々の研究においてTGF- $\beta$ スーパーファミリーの1つであるアクチビンと特 異的に結合するアクチビン型IIB受容器（ActRIIB）およびSmad2を介したアクチビンシグナル伝達系は 膵 $\beta$ 細胞自体の大きさのみならず、インシュリン分泌を調節することが明らかとなった (Nomura et al., Diabetologia, 2014)。一方、膵 $\beta$ 細胞におけるアクチビンシグナル伝達系の働きのみを増強した場合、膵 $\beta$ 細胞の大きさのみならず、インシュリン分泌がどのように制御されるかについては未だ不明のままであ る。今回、膵細胞における一連のアクチビンシグナル伝達系の重要な生理学的役割を解明するために、 Cre-loxPシステムを用い、膵 $\beta$ 細胞に扔けるアクチビン型IB受容器 (ActRIB) を介したアクチビンシグナ ル系のみを活性化したマウス（膵 $\beta$ 細胞特異的ActRIB遺伝子組み換え $(\mathrm{Tg})$ マウス:ActRIBCA $\beta$ Tg マウス) を作製した。個体レベルではActRIBCA $\beta$ Tgマウスは、グルコース刺激によるインスリン分泌損および 耐糖能の異常を呈したが、膵 $\beta$ 細胞の大きさについては野生型マウスとActRIBCA $\beta \operatorname{Tg}$ マウスの両者を比較 しても有意な差は観察され無かった。またActRIBCA $\beta T$ Tの膵 $\beta$ 細胞にパッチクランプ法を適用し、ATP感 受性 $\mathrm{K}^{+}$チャンネル $\left(\mathrm{K}_{\mathrm{ATP}}\right.$ チャンネル）活性を記録するとインサイドアウト後の $\mathrm{K}_{\mathrm{ATP}}$ チャンネル活性化が 減弱していることが明らかになった。以上の結果から、膵 $\beta$ 細胞のアクチビンシグナル系の “適切なレベ ル’でのActRIIB発現がグルコース刺激によるインスリン分泌の制御に対して重要であり、アクチビンシ グナル系は $\mathrm{K}_{\mathrm{ATP}}$ チャンネル活性機序にて調節を受けていることが示唆された。 


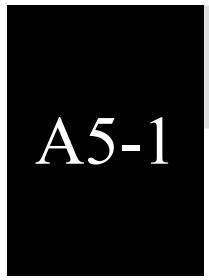

\section{P2X3受容体を介した、脊髄後角抑制性介在ニューロンの興奮 性シナプス伝達の調節}

○古賀啓祐 ${ }^{1}$ 、津田 誠、井上和秀、井本敬二 ${ }^{2}$ 、古江秀昌 ${ }^{3}$

(九州大院・薬・薬理、ライフイノベーション、

${ }^{3}$ 自然科学研究機構・生理研・神経シグナル研究部門)

脊髄後角は末梢から入力する感覚情報の伝達や調節に重要である。すなわち、脊髄後角には、脳に感 覚情報を伝達するprojectionニューロンだけでなく、抑制性及び興奮性の介在ニューロンが存在し、末梢 からの感覚情報を調節する役割を果たす。特に、脊䯣後角の抑制性介在ニューロンは、後角ニューロン の興奮を有効に抑えることで、痛みの抑制や、感覚間の相互作用に重要である。実際にこの抑制性と興 奮性のバランスが崩れることで異常な感覚伝達が引き起こされることが知られている。一方、一次求心 性感覚神経に発現するP2X3受容体を活性化すると痛覚過敏が発症することが知られているが、その神経 回路メカニズムの詳細は不明である。そこで本研究では、春髄中枢においてP2X3受容体の活性化が春䯣 後角抑制性介在ニューロンのシナプス伝達に変調をきたす可能性を考え、電気生理学的な手法を用いて 詳細な検討を行った。抑制性ニューロン特異的に蛍光タンパク質Venusを発現するラットから急性脊䯣 スライスを作製し、抑制性ニューロンから記録を行った。一次求心性神経の神経線維を電気刺激すると 刺激間值と伝導速度の異なるA線維抢よびC線維を介した興奮性シナプス後電流（EPSC）が記録された。 $\mathrm{P} 2 \mathrm{X} 3$ 受容体刺激の影響を検討するためP2X3受容体アゴニストを潅流投与したところ、C線維を介した EPSCでのみその振幅の抑制が見られた。さらにPaired Pulse Ratio (PPR)を検討したところ、P2X3受容体 アゴニスト潅流投与により PPRは増加した。このことから、シナプス前のP2X3受容体の活性化によりC 線維からのグルタミン酸の放出が抑制されることが示された。したがって、P2X3は脊髄において抑制性 ニューロンへの興奮性の入力を減弱し、これにより抑制性と興奮性のバランスが崩れることで、異常な 感覚伝達を引き起こすことが示唆された。

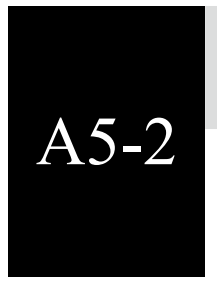

\section{痒み発症における一次求心性神経P2X3受容体の関与}

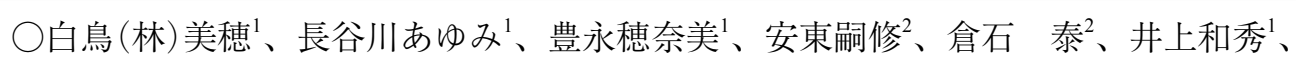

津田 誠,

( ${ }^{1}$ 九州大院・薬・薬理、富山大院・医薬・応用薬理、 ${ }^{3}$ 九州大院・薬・ライフイノベーション)

“痒み”は外界の有害物質に対する生体の自己防衛システムの一つである。しかしその一方で、多くの 皮膚及び全身疾患に伴う慢性的で強い痒みは、抗ヒスタミン薬など既存の治療薬に抵抗性を示し、患者 のQOLを著しく低下させる。そのため、難治性の痒みメカニズム解明及び治療薬開発は急務の課題であ る。近年、一次求心性神経に発現するヒスタミン受容体とは異なる受容体が難治性の痒み発症に関与す る可能性が示唆されている。このことから、一次求心性神経に存在する新たな痒み受容体を明らかにす ることは難治性の痒みメカニズム解明に大きく寄与すると想定される。

P2X3受容体は、一次求心性感覚神経に選択的に高発現しているイオンチャネル型ATP受容体であり、 感覚情報の発生や伝達への関連が示唆されている。しかし、痒みにおける役割は不明である。そこで本 研究では、一次求心性神経P $2 X 3$ 受容体の痒み発症における関与を検討した。P2X3受容体作動薬及び内 因性リガンドであるATPのマウス㚘への投与により痒み行動が増加し、その増加はP2X3受容体拮抗薬に より抑制された。最近、MrgprA3陽性一次求心性感覚ニューロンが痒み特異的であることが報告された (Nat. Neurosci., 2013)。そこで、マウスの後根神経節（DRG）及び三叉神経節（TG）ニューロンにおけ るP2X3受容体作動薬とMrgprA3作動薬の応答性をCaイメージング法により検討した結果、両作動薬に応 答するDRG及びTGニューロンが確認された。さらに、MrgprA3陽性ニューロンの活動性を抑制したマウ スではP2X3受容体作動薬による痒み行動増加が抑制された。また、脊髄後角ニューロンに発現する痒み 特異的受容体であるGRP受容体（Nature, 2007）を欠損したマウスにおいてP2X3受容体作動薬による痒 み行動が有意に抑制された。以上の結果から、MrgprA3陽性一次求心性感覚神経に発現するP2X3受容体 の活性化により春髄後角GRP受容体依存的な痒みが発症する可能性が示唆された。 


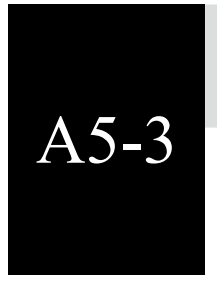

\section{神経障害性疼痛モデルマウスの脊䯣内におけるATP放出量の増 加とVNUTの役割}

○大園由衣 ${ }^{1}$ 、増田隆博 ${ }^{1,2}$ 、御厨颯季 ${ }^{1}$ 、齊藤秀俊 ${ }^{1,2}$ 、津田 誠 ${ }^{1,3}$ 、井上和秀 1,2

$\left({ }^{1}\right.$ 九州大院 ·薬 ·薬理、 ${ }^{2} \mathrm{CREST} 、{ }^{3}$ 九州大院・薬 · ライフイノベーション)

神経障害性疼痛とは、糖尿病や末期癌に伴う神経系の損傷や機能異常により引き起こされ、触刺激等 の非侵害性の刺激によって激烈な痛みを生じるアロディニアを主症状とする難治性疼痛である。我々は これまでに、末梢神経損傷後に活性化した春髄ミクログリアにおいて発現増加するP2X4受容体等のATP 受容体が、神経障害性疼痛発症に重要な役割を果たしていることを明らかにしてきた。しかしながら、 ATP受容体を刺激する細胞外ATPの放出については全く明らかになっていない。そこで本研究では、ATP の貯蔵や放出に重要な役割を果たす小胞型ヌクレオチドトランスポーター（VNUT）に着目し、ATP供 給および神経障害性疼痛への関与について詳細な解析を行った。

第4腰髄脊髄神経を切断した神経障害性疼痛モデルマウスの正常側および神経損傷側脊髄スライス標本 を作成し、脊髄スライスから放出されるATP量をそれぞれ測定した。その結果、神経損傷側春髄で有意 に細胞外ATP量が増加していた。一方、興味深いことに、このATP量の増加は、VNUT欠損マウスにおい ては全く見られなかった。さらに、神経損傷後に見られるアロディニア症状は、野生型マウスと比較し て、VNUT欠損マウスで顕著に抑制された。

以上の結果から、末梢神経損傷後、春髄内でVNUTを介して増加した細胞外ATPが、神経障害性疼痛の 発現に重要な役割を果たしていることが示唆された。

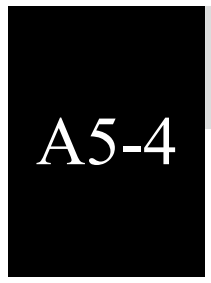

\section{ミクログリアBKチャネルを介したモルヒネ鎮痛耐性及び痛覚} 過敏メカニズム解明

○林 良憲、中西 博

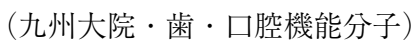

モルヒネに代表されるオピオイドは強力な鎮痛薬として臨床的に使用されている。現在では非ガン性 の慢性疼痛に拈いても適用が広がっているが、長期的な投与により副作用及び依存性についての問題が 指摘されている。代表的な副作用に薬効が減弱する鎮痛耐性がある。適切な鎮痛効果を得るために投与 量の漸増が必要となり、便秘や嘔吐といった副作用のリスクの増大に繋がるため適切なモルヒネの使用 法の確立が必要である。これまで、低用量のケタミンがモルヒネ鎮痛耐性を抑制することがケースレポー トで報告されているが、そのメカニズムは不明である。我々はケタミンの新たな作用部位としてミクロ グリアのBKチャネルを報告してきた。そこでモルヒネによる鎮痛耐性がミクログリアBKチャネルに由 来しているか検討を行った。モルヒネの連投により生じる鎮痛耐性はBKチャネル阻害剂の髄腔内投与に より改善した。この際、脊髄ミクログリアにおけるBK電流は耐性の抑制程度と相関を示した。またBK チャネル阻害剤によりモルヒネ誘発性痛覚過敏も有意に抑制した。モルヒネで刺激したミクログリアを 髄腔内投与したところ鎮痛耐性および痛覚過敏の形成が促進された。これらの現象はBKチャネル阻害剂 処置群あるいはBKチャネル欠損ミクログリア投与群では消失した。BKチャネル活性化メカニズムを解 析したところ、 $\mu$ 受容体を介したアラキドン酸カスケードにより生じる脂質によりBKチャネルが活性化 されていることが明らかとなった。更にBKチャネルの役割を解析した結果、疼痛に重要とされるP $2 \mathrm{X} 4$ 受容体の膜輸送への関与が認められた。以上の結果よりミクログリアBKチャネルが鎮痛耐性挔よび痛覚 過敏の形成に重要な役割を担う事が明らかとなった。これらの知見によりオピオイドの補助薬としての 開発の可能性が期待できる。 


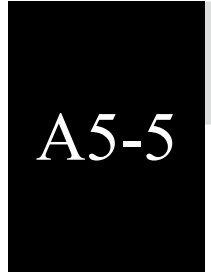

\section{断続的冷温負荷による線維筋痛症モデルに対するドネペジルの 疼痛改善作用}

○内田仁司、迎 武紘、植田弘師

(長崎大院・医菌薬・創薬薬理)

急性疼痛は生体警告系としての生理的役割を果たしているが、慢性疼痛には生理的意義がなく、それ 自身が疾患であると捉えられている。また、慢性疼痛は「痛みの悪循環」とそれに続く「痛みの記憶」 が形成維持されることから、早期診断および早期治療が望まれる。線維筋痛症は、原因不明の全身性疼 痛を主症状とし、多様な精神神経症状や自律神経症状を随伴症状とする難治性疾患である。本疾患の有 病率は人口の約 $2 \%$ 占めるにもかかわらず、診断マーカーが欠如しており、このことが早期診断および 早期治療への大きな障壁となっている。また、線維筋痛症治療薬として、抗痮攣薬や抗うつ薬が一定の 効果を示しているが、根本的な治療法は確立されていない。よって、線維筋痛症の病態解明とそれに基 づく治療戦略の確立は、喫緊の研究課題である。

これまでに我々は、線維筋痛症の発症要因である慢性ストレスに着目し、断続的冷温ストレス (intermittent cold stress, ICS) 負荷による病態モデルマウスを確立してきた（Nishiyori and Ueda, Mol Pain, 2008; Nishiyori et al., Neurosci Lett, 2010; Nishiyori et al., Mol Pain, 2011)。本モデルでは、両側性か つ雌性優位性の疼痛過敏㧍よびアロディニアが長期的に観察される。また、臨床的知見と一致して、本 モデルは抗痤攣薬（ガバペンチン）と抗うつ薬（ミルナシプランなど）に感受性であるが、モルヒネに 抵抗性を示す。以上のことから、本モデルは、線維筋痛症の臨床病態と治療薬応答性をよく反映してお り、病態解明とそれに基づく創薬研究に適していると考えられる。一方、最近では、線維筋痛症に扔け る疼痛症状と随伴症状は、その病態メカニズムを共有する可能性が示唆されており、新たな治療戦略が 提案されつつある。そこで今回、線維筋痛症の随伴症状、特に乾燥症状などの自律神経系の異常に着目 し、その治療薬であるピロカルピンの有効性を評価した。さらに、コリンエステラーゼ阻害薬であるド ネペジルについても解析を行ったので、本発表では、これらの成果について報告する。

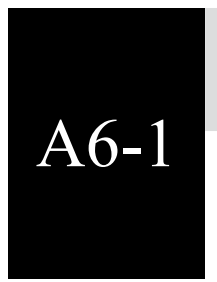

\section{P19細胞におけるAmyloid precursor protein (APP)の神経分化へ の影響}

$\bigcirc$ 二川俊隆 ${ }^{1}$ 高濱和弘 ${ }^{1}$ 益田将吾 ${ }^{2}$ 、山田勝士 ${ }^{3}$ 、池田龍二 ${ }^{1,2}$ 、武田泰生 ${ }^{1,2}$

( ${ }^{1}$ 鹿児島大病院・薬剂部、永児島大院・医歯・薬物動態制御

長崎国際大・薬・臨床薬理)

【背景】膜貫通型タンパク質であるAmyloid precursor protein (APP) は神経変性疾患であるアルッハイマー 型認知症 $(\mathrm{AD})$ の原因タンパク質として知られている。 $\mathrm{AD}$ 患者にみられる老人斑は、APPの前駆体か ら sheddingにより産生された $\mathrm{A} \beta$ が遊離し、海馬や皮質で異常に蓄積して生じると考えられている。ま

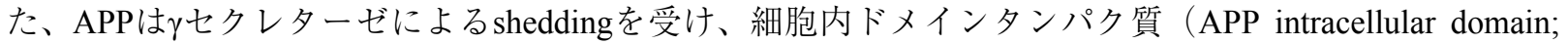
AICD）の遊離が起こる。2009年にはGhosalらにより、AD患者脳でのAICD蓄積が報告された。さらにこ れまで、当研究室より、APPがマウス胎仔脳において発生初期の段階から神経幹細胞に発現すること、 さらに、APPが神経分化を調節していることを報告した。しかしながら、APPの詳細な神経分化過程調 節機構は明らかでない。そこで本研究では、APPの神経分化過程調節機構を詳細に検討した。

【方法】マウス胚性腫瘍（EC）細胞であるP19細胞は、レチノイン酸（RA）により分化誘導され、神経 細胞㧍よびアストロサイトに分化することが知られている。P19細胞株にhAICD-pCDNA4をRA存在下に おいて一過性に導入し、AICDがRA誘導による分化過程にどのような影響を及ぼすかを定量的PCR法お よびRT-PCR法を用いて検討した。

【結果・考察】定量的RT-PCR法の結果、AICD導入細胞およびコントロール細胞をRA処理し、sphere様の 細胞塊を形成させたところ、AICD導入細胞がコントロール細胞と比較して幹細胞マーカーである Oct4 mRNAが増加した。また分化過程においてAICD導入細胞において神経マーカーであるTuj1 mRNAが減少 した。これらの検討で、AICDは、P19細胞において神経分化を抑制する作用があり、Oct4の発現上昇が、 神経分化の調節に寄与した可能性が示唆された。今回得られた結果を踏まえて、さらに詳細な検討が必 要であり、AICDが関わる神経分化の細胞内シグナル伝達機構の全貌を明らかにしていきたいと考えてい る。 


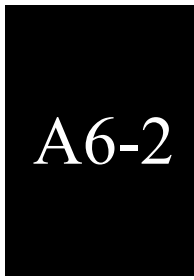

\section{ドーパミンD1受容体アゴニストとSSRIの併用投与がマウスの うつ様行動に与える影響}

○首藤隆秀、黒岩真帆美、外角直樹、西 昭徳

(久留米大·医 · 薬理)

【目的】海馬歯状回は抗うつ薬の重要な作用部位の一つと考えられている。当研究室では、抗うつ薬を 14 日間慢性投与した結果、10日目以降よりマウスの海馬歯状回においてドーパミンD1受容体の発現量が有 意に増加するという実験結果を得た。したがって本研究では、抗うつ薬の作用発現におけるドーパミン D1受容体シグナルの役割を検討するために、抗うつ薬とドーパミンD1受容体アゴニストの併用投与がマ ウスのうつ様行動に与える影響を評価した。

【方法】うつ病モデルとして、C57BL/6マウスを用い、軽度ストレス負荷（1日2時間拘束 $\times 14$ 日間）と重 度ストレス負荷（1日4時間拘束 $\times 28$ 日間）の2種類の慢性拘束ストレス負荷マウスを作成した。抗うつ薬 慢性投与は、SSRIフルオキセチンの徐放性ペレット（15 mg/kg/day）を皮下に埋込み14日間行った。ドー パミンD1受容体アゴニストR-(+)-SKF81297 (1.5 mg/kg, i.p.) の併用投与は、ドーパミンD1受容体の増加 が顕著となるフルオキセチン投与10日目から14日目までの5日間に1日1回行った。抗うつ効果の評価は新 規環境雎食抑制試験（novelty-suppressed feeding test）と尾懸垂試験（tail suspension test）により行った。 【結果】フルオキセチン単独投与群は、軽度ストレス負荷マウスではうつ様行動を抑制したが、重度スト レス負荷マウスではうつ様行動の抑制効果は得られなかった。しかしながら、フルオキセチンとドーパ ミンD1受容体アゴニストの併用投与群は、重度ストレス負荷マウスに掞いてうつ様行動の抑制を示した。 【考察】ドーパミンD1受容体アゴニストの併用によりフルオキセチンの抗うつ作用が増強することが示 唆された。本研究の結果より、抗うつ薬の慢性投与により惹起される海馬歯状回のドーパミンD1受容体 シグナルの増強が、抗うつ作用に関与すると考えられる。

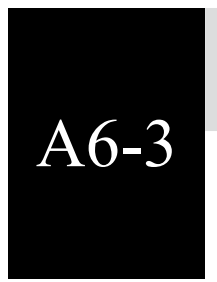

\section{Chronic treatment with citalopram suppresses stress response of cortical DA but not NA: an evidence for involvement of $5-\mathrm{Ht}_{1 \mathrm{~A}}$ receptors}

OFumi Kaneko ${ }^{\text {a }}$, Yukie Kawahara ${ }^{\text {a }}$, Yuki Kishikawa ${ }^{a}$, Makiko Yamada ${ }^{\text {a,b }}$, Hiroshi Kawahara ${ }^{c}$, Akinori Nishi ${ }^{a}$

( ${ }^{\mathrm{a}}$ Department of Pharmacology, Kurume University School of Medicine,

${ }^{b}$ Department of Psychiatry, Tokyo Women's Medical University,

${ }^{\mathrm{c}}$ Department of Dental Anesthesiology, School of Dentistry, Tsurumi University)

Introduction Cortical dopamine (DA) and noradrenaline (NA) are involved in the stress response. Citalopram, an SSRI, is known to have direct and indirect effects on the serotonergic neural system. Chronic administration of citalopram also affects DA and NA neurons, which could contribute to remission of psychiatric symptoms. Here, we investigated the effects of chronic citalopram treatment on the responses of DA and NA in the prefrontal cortex (PFC) to acute stress. Materials and methods Male Wistar rats were used. Rats received citalopram hydrobromide $(10 \mathrm{mg} / \mathrm{kg}$ s.c.) or saline $(0.2 \mathrm{ml}$ s.c. for the control $)$ for 14 days. The DA and NA levels in the PFC were measured by microdialysis. Handling was applied for $20 \mathrm{~min}$ as an acute mild stressor. Results Handling stress induced the increases in DA and NA levels, and the stress response of DA, but not $\mathrm{NA}$, was suppressed with chronic citalopram treatment. Pharmacological analyses revealed an ability of 5- $\mathrm{HT}_{1 \mathrm{~A}}$ receptors to suppress the stress responses of both DA and NA. Furthermore, a critical role of $5-\mathrm{HT}_{1 \mathrm{~A}}$ receptors in chronic citalopram-induced suppression of the stress response of DA was indicated. Conclusion Chronic citalopram treatment selectively suppresses the stress response of DA in the PFC via up-regulation of 5- $\mathrm{HT}_{1 \mathrm{~A}}$ receptor signaling. Our findings provide insight into how antidepressants modulate DA and 5-HT systems to overcome acute stress. 


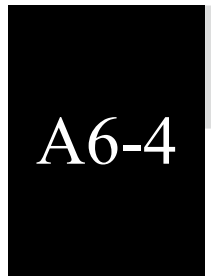

\section{リポソーム添加型無細胞蛋白質合成系による膜蛋白質の合成： ドパミン $\mathrm{D}_{1}$ 受容体の発現と受容体結合能解析}

○有光英治 ${ }^{1,2}$ 、小笠原富夫 ${ }^{3} 、$ 日浅陽一 ${ }^{2}$ 、澤崎達也 ${ }^{3}$ 、前山一隆 ${ }^{1}$

(愛媛大院・医・統合生体情報・薬理、先端病態制御内科

3 愛媛大・無細胞生命科学工学研究センター）

【背景】G蛋白質共役型受容体（GPCR）は細胞膜を7回貫通する特徵を持ち、細胞内シグナル伝達を行う。 GPCRを合成することは困難であり、これまでその構造機能的な研究は進んでこなかった。近年、人工 的な膜構造（リポソーム）の存在下で膜蛋白質を合成する試みが報告されている。今回、我々はリポソー ムの存在下に小麦胚芽を用いた無細胞蛋白質合成系を組み合わせてドパミン $\mathrm{D}_{1}$ 受容体蛋白を発現し、受 容体の結合能について検討したので報告する。

【方法】小麦胚芽抽出液を用いた無細胞蛋白質合成系にてリポソーム存在下でドパミン $\mathrm{D}_{1}$ 受容体蛋白質を 発現させた。対照としてラット線条体膜分画を用いた。受容体の特異的結合は放射性標識した $\mathrm{D}_{1}$ 受容体

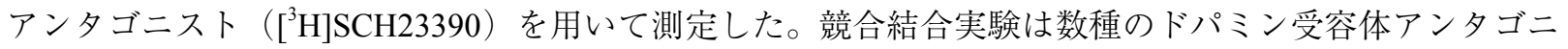
スト、アゴニストを用いた。

【結果と考察】Scatchard plot 解析より結合親和性 $(\mathrm{Kd})$ と最大結合数（Bmax）が算出され、リポソーム 蛋白質では6.61 nM、1.85 pmol/ $/ \mathrm{mg}$ proteinであり、対照実験のラット脳組織では $2.67 \mathrm{nM} 、 0.70 \mathrm{pmol} / \mathrm{mg}$ proteinであった。競合結合実験において各種アンタゴニスト、アゴニストの平衡解離定数 $(\mathrm{Ki})$ が算出され た。アンタゴニストのKi值は両群間で比較的近似したが、アゴニストのKi值はリポソーム蛋白質群のほ うが約 $5 \sim 17$ 倍高い值となった。

以上より、無細胞蛋白質合成系により発現したドパミン $\mathrm{D}_{1}$ 受容体蛋白質は機能的な結合能を有してい ることが示唆されたが、発現したリポソーム蛋白質にはシグナル伝達に必要なG蛋白質が含有されてお らず、アゴニストへの親和性に影響を及ぼした可能性が考えられる。

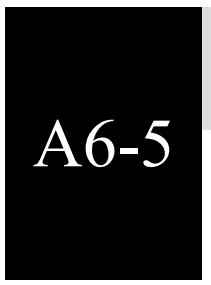

\section{ABCB6は5-FUやSN-38、Vincristineの耐性に関与する}

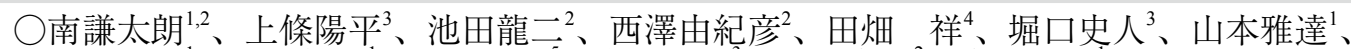

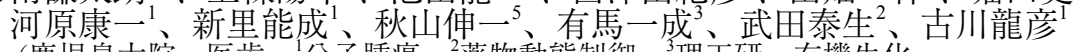

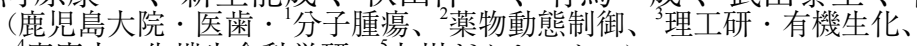

慶應大・先端生命科学研、 ${ }^{2} 九$ 九洲がんゼター)

七素は前骨髄球性白血病の治療に使われている。また、in vitro、in vivoで食道がんや卵巣がん、前立 腺がん細胞でアポトーシス促進性の効果が報告されている。しかし、ヒ素に対する耐性が報告されてお り、治療の障害となっている。

すでに我々はヒト類表皮癌KB3-1細胞からヒ素耐性細胞KAS細胞を樹立した。この細胞はヒ素に対し て20倍の耐性で、ヒ素の排出が六進していた。また、cisplatin, doxorubicin, vincristine等の抗がん剤にも耐 性であった。今回KAS細胞の耐性機構を明らかにすることを目的に解析を行った。

KAS細胞はヒ素の排出能が㐫進していたことから、排出型の輸送体蛋白質ABCトランスポーターに注 目し、KAS細胞での発現を調べた。KAS細胞でABCC1/MRP1とABCB6のmRNAとタンパク質の発現が KB3-1細胞よりも増加していた。一方、以前の解析でKB3-1細胞由来のABCC1/MRP1を高発現している抗 がん剂多剂耐性細胞C-A120はヒ素対して2.6倍の耐性度しかなかったので、ABCB6に着目し、KB3-1細胞 にABCB6を強制発現した細胞とABCB6をノックダウンしたKAS細胞を用いて解析を行った。

ABCB6強制発現細胞はKB3-1細胞と比べてヒ素に対する耐性度に有為な変化がなかったが、5-FU、 SN-38、vincristineに対して耐性であった。逆に、ABCB6をノックダウンさせたKAS細胞ではこれらの 薬剂に対して感受性が上昇したが、ヒ素の感受性には変化がなかった。ABCB6と5-FUの耐性との関連 を確かめるために、ヒト大腸がん細胞KM12Cとその5-FU耐性細胞株KM12C-FUでABCB6発現を調べた。 その結果、KM12C-FUは親細胞よりABCB6のmRNA発現が約2.5倍高いことがわかった。

今回の結果から、ABCB6は5-FUやSN-38、Vincristineの耐性に関与していることが示唆された。 


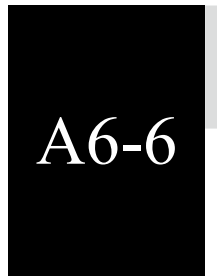

緑膿菌大腿部感染マウスモデルを用いたパズフロキサシンの pharmacokinetics-pharmacodynamics (PK-PD) パラメー夕に基づく薬効解析

○梅㟝靖弘 ${ }^{1,2}$ 、松元一明 ${ }^{2}$ 、横山雄太 ${ }^{1,3}$ 、大坪靖治 ${ }^{4}$ 、永友寛一郎 ${ }^{4}$ 、高橋義博 ${ }^{4}$ 、

猪川和朗 ${ }^{3}$ 、森川則文 ${ }^{3}$ 、武田泰生

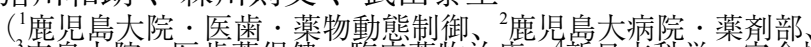

広島大院・医歯薬保健・臨床薬物治療、新日本科学・管全性研

【目的】近年、抗菌薬はpharmacokinetics-pharmacodynamics（PK-PD）に基づき、AUC/MIC、Cmax/MIC、 Time above MICに分類されるPK-PDパラメータに従い、投与量、投与間隔を決定することが推奨されて いる。しかし、緑膿菌に対するパズフロキサシンの投与量を決定するための最適なPK-PDパラメータお よび投与方法は明らかになっていない。そこで今回、緑膿菌大腿部感染マウスモデルを用いて、パズフ ロキサシンの薬物動態と抗菌効果についてPK-PD解析を行い、最も相関するPK-PDパラメータを明らか にしたので報告する。

【方法】5週齢ddy系マウスを用いた。パズフロキサシン2.5、10、40 mg/kgを投与後、継時的（10-120分） に血液を採取し、まず、高速液体クロマトグラフを用いて血中濃度を測定した。次に、シクロホスファ ミドを投与して易感染状態にしたマウス大腿部に緑膿菌の標準株であるATCC27853、6 $\times 10^{4} \mathrm{CFU} /$ 大腿部 を接種し、その2時間後からパズフロキサシンを $5-35 \mathrm{mg} / \mathrm{kg} /$ 回で各種濃度・投与間隔で皮下投与を開始し、 その24時間後における大腿部の生菌数を測定した。薬物動態パラメー夕の算出およびSigmoid Emaxモデ ル解析にはプログラムMULTIを用いた。

【結果・考察】薬物動態と緑膿菌による大腿部感染マウスモデルに対するパズフロキサシンの効果を比較 検討したところ、遊離型薬物濃度 $(f)$ 基準のPK-PDパラメータとして、 $f$ Time above MIC $(\mathrm{r}=0.531)$ に 比べて、 $f \mathrm{C}_{\max } / \mathrm{MIC}(\mathrm{r}=0.809)$ および $f \mathrm{AUC} / \mathrm{MIC}(\mathrm{r}=0.847)$ が高い相関を示した。そして、最も高い相関 を示したパラメータであるfAUC/MICが63.8の場合に、1 log kill効果を示し、100.8の場合に、2 log kill効果

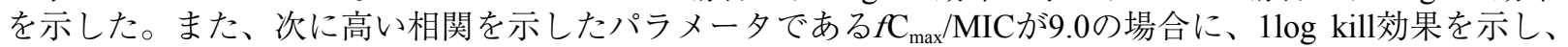
13.5の場合に、2 $\log$ kill効果を示した。したがって、緑膿菌による感染症に対して、パズフロキサシンは $\mathrm{fAUC} / \mathrm{MIC}$ が100以上、かつ $\mathrm{C}_{\max } / \mathrm{MIC}$ 以゙14以上になるように投与設計することで、有効な治療薬になると 考えられた。

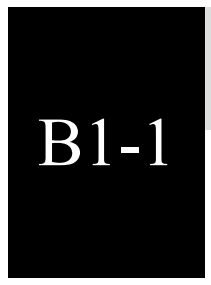

\section{徳島産ラッパウニの叉棘に由来するレクチンの多様性について}

江戸 梢 ${ }^{1} 、$ 酒井仁美 2 、吉野真生子 ${ }^{2} 、 \bigcirc$ 中秀幸 ${ }^{2}$

('四国大・短大部、“徳島大 ・院総合・環境共生)

【目的】ラッパウニ科のラッパウニは、体表を覆う球状の棘（大型叉棘）にタンパク質毒を持っている。 この叉棘に刺されると、痛みや腫れなどが生じる。これまでの結果より、徳島産ラッパウニの大型叉棘 からのタンパク質毒は主にレクチンであると推定されている。そこで今回、ラッパウニの大型叉棘に由 来する新規レクチンについて探索を行った。

【方法】徳島県南の沿岸で採集したラッパウニ（20個体）から、大型叉棘を採取し生理食塩水で抽出を行 い、大型叉棘標品とした。大型叉棘タンパク質画分の糖鎖染色はSDS-PAGEを利用して、染色キットを 用いた。赤血球凝集活性はウサギ赤血球を用いて測定し、マイトジェン活性はマウス脾細胞及び脾細胞 由来T細胞においてMTT法により測定し、サイトカインの定量はELISA法で行った。大型叉棘レクチンの 精製は、叉棘標品をSuperdex 200カラムとPhenyl Sepharose CL-4Bカラムの組み合せにより行った。

【結果】大型叉棘標品を 2 種のカラムクロマトグラフィーを用いて、32 kDaレクチンを精製した。このレ クチンの部分アミノ酸配列は、すでに大型叉棘標品から精製されているD-ガラクトース結合性レクチン のSUL-I (32 kDa) と類似しており、レクチンはSUL-IAと命名された。SUL-IAはマウス脾細胞及び脾細胞 由来T細胞に対してマイトジェン活性を示したが、このマイトジェン活性はD-ガラクトースの添加によ り阻害された。また、SUL-IAはT細胞において、1 型ヘルパーT細胞（Th1）に関連するIFN- $\gamma$ 産生した。 以上のことから、ラッパウニの大型叉棘はSUL-Iに加えてSUL-IAなどのレクチンを産生することが考え られた。 


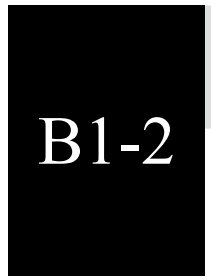

\section{培養肺胞上皮細胞でのTLR5刺激によるEGF受容体のリン酸化 反応}

○山本秀幸 ${ }^{1}$ 、野口信弘 ${ }^{1,2}$ 、西 啓亨 ${ }^{1,2}$ 、前田紀子 ${ }^{1}$ 、仲嶺 (比嘉) 三代美 ${ }^{1}$ 徳 誠吉 ${ }^{1} 、$

須加原一博 ${ }^{2}$

(琉球大院・医 $\cdot{ }^{1}$ 生化、麻酔科)

フラジェリンは細菌の鞭毛の構成タンパク質であり、Toll-like receptor 5 (TLR5)を刺激することが知 られている。我々は、肺胞上皮細胞様の特徵を有するA549細胞では、フラジェリン処理により、p 38 MAPキナーゼが活性化されることを見いだした ${ }^{1)}$ 。今回、フラジェリン処理による上皮成長因子受 容体（EGFR）のリン酸化反応について検討した。30分間の処理により、EGFRの1047番目のセリン 残基（Ser1047）のリン酸化が増加した。このリン酸化は、p38 MAPキナーゼによって活性化される MAPKAPK2の阻害剤によって完全に消失した。次に、GST-MAPKAPK2を大腸菌の発現系を用いて精製 した後、活性化型ERKにより活性化させた。また、EGFRをHEK293T細胞で発現させた後、免疫沈降法 により分離した。分離したEGFRは、活性化させたGST-MAPKAPK2により、Ser1047がリン酸化された。 今回、MAPKAPK2がEGFRをリン酸化することが初めて明らかになった2)。TNFa処理によるSer1047のリ ン酸化は、EGFRのエンドサイトーシスを引き起こすことが報告されており、TLR5刺激もEGFRの脱感作 を引き起こす可能性がある。

1) Am. J. Physiol. Lung Cell. Mol. Physiol. 303: L1057-L1069 (2012)

2) Arch. Biochem. Biophys. 529: 75-85 (2013)

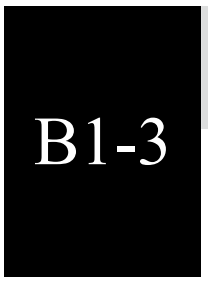

\section{閉塞性肺疾患モデルマウスにおける内因性ビタミンCの役割}

○首藤 剛 ${ }^{1} 、$ 坂口由起 ${ }^{1} 、$ 野原寛文 ${ }^{1,2} 、$ 刍井竣輔 ${ }^{1,2} 、$ 藤川春花 ${ }^{1}$ 近藤嘉高 ${ }^{3} 、$

Mary Ann Suico ${ }^{1}$ 、石神昭人 3 、甲斐広文 ${ }^{1,2}$

(熊本大院・薬・遺伝子機能応用、2熊本大・リーディング大学院HIGOプログラム、

菄京健康長寿医療七研・老化制御研究・分子老化制御)

慢性閉塞性肺疾患 (COPD) は、慢性の咳嗽、喀痰、労作時呼吸困難を主徵とする難治性の呼吸器疾患 である。本分野では、気道特異的上皮型ナトリウムチャネル (ENaC) 過剩発現マウス (ENaC-Tgマウス) が、粘液貯留・肺気腫・呼吸機能障害を呈し、さらに、酸化ストレスやプロテアーゼ活性が光進した COPD様症状を呈することを明らかにしてきた。一般にCOPDの発症および増悪には、生体内における酸 化物質-抗酸化物質のバランスの崩壊が強く関与することが知られているが、 ENaC-Tgマウスにおいて、 内因性酸化ストレスが肺病態形成にどの程度関与しているのかは不明である。そこで、本研究では、マ ウス体内で産生される内因性抗酸化物質ビタミンC (VC) の肺病態形成における役割を明らかにすること を目的とした。まず、内因性VC合成酵素SMP30を欠損したノックアウト (KO) マウスとENaC-Tgマウス を交配し、内因性VCを体内で産生できない雌雄のENaC-Tg-SMP30 KOマウスをそれぞれ作製した。次 に、これらのマウスにVC欠損食を与え、VC欠損ENaC-Tgマウスを作成し、その肺病態について検討した。 その結果、SMP30が久損した雌雄のENaC-Tgマウスは、SMP30非欠損ENaC-Tgマウスと比較して、肺組 織に打ける酸化ストレス関連遺伝子、血清中の $\mathrm{H}_{2} \mathrm{O}_{2}$ 量が有意に上昇し、酸化ストレス状態が充進した。 また、内因性VCの欠損は、ENaC-Tgマウスの肺組織における粘液および炎症関連遺伝子のmRNA発現を 上昇させ、さらにマウス肺気腫病態の悪化、呼吸機能の低下を有意に促進させた。以上、本研究は、閉 塞性肺疾患モデルENaC-Tgマウスの肺病態形成において、内因性VCが重要な役割を担うことを初めて明 らかにした。また、本研究において作製したENaC-Tg-SMP30 KOマウスは、ヒトと同様に内因性VCを合 成できないことから、本マウスは、ヒトの重篤なCOPD病態を再現する、世界で初めての新規COPDマウ スモデルであるといえる。 


\section{大建中湯の抗線維化・抗狭窄作用における消化管筋線維芽細胞 TRPA1の役割} B1-4

○倉原 (海) 琳ㄴ.住吉美保、青柳邦彦 ${ }^{2}$ 平石敬三 ${ }^{1}$ 、井上隆司 ${ }^{1}$

(福岡大·医・生理、消化器内科)

【背景】大建中湯は術後イレウスや炎症性腸疾患に打ける線維化狭窄の治療薬として用いられてきた。 我々は、腸管線維化狭窄で大きな役割を果す「筋線維芽細胞」を用いて、多様な刺激に反応するTRP チャネルと線維化狭窄の関係について検討し、ヒト消化管筋線維芽細胞株InMyoFibで最も多く発現する TRPA1が大建中湯の抗線維化狭窄作用にどのように関わるのかを検討した。

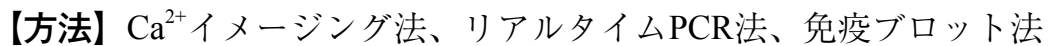

【結果】大建中湯およびその有効成分がInMyoFibに及ぼす効果を検討した。(1)[6]-shogaol 、hydroxyl- $\alpha$ sanshool、大建中湯エキス、乾姜エキス、山椒エキスはInMyoFibへのTRPA1を介する $\mathrm{Ca}^{2+}$ 流入を惹起した。 (2)大建中湯エキスはTRPA1の発現を有意に促進した。(3)大建中湯エキスはTGF $\beta 1(5 \mathrm{ng} / \mathrm{ml})$ 刺激によっ て活性化されるSmad-2、p38 MAPKのリン酸化を抑制して、タイプIコラーゲンの発現を抑制した。(4)大 建中湯エキスは単独でタイプIIIコラーゲンのmRNA発現を抑制した。(5)siRNAによってTRPA1をノックダ ウンすると、線維化刺激因子TGF $\beta 1$ 下流のSmad-2リン酸化が増強された。

【考察】以上のことから、大建中湯に含まれる乾姜や山椒の成分は、消化管筋線維芽細胞のTRPA1千ャ辛 ルを活性化し、大建中湯はTRPA 1 チャネルの発現を増やすことによってTGF $\beta 1$ 刺激下流の線維化シグナ ルを抑制していることが明らかとなった。これらの結果は大建中湯の抗線維化効果の作用機序として重 要であると考えられる。

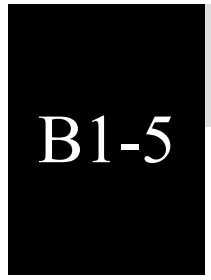

\section{アセトアミノフェン誘発肝障害の新規治療戦略としての小胞体} ストレス制御の可能性評価

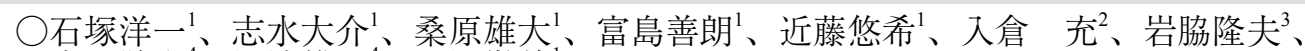

宮田敬士 ${ }^{4} 、$ 尾池雄一 ${ }^{4} 、$ 入江徹美

(1熊本大院·薬・薬剤情報分析、2第一薬大·臨床薬剤、

群馬大・先端科学研究指導者育成ユニット、熊本大院・医・分子遺伝 $)$

【目的】解熱・鎮痛薬アセトアミノフェン (APAP) は、誤飲や自殺企図などで過量服用された際に、重 篤な肝障害を誘発するため世界中で問題となっており、病態機序の解明および新規治療薬の開発が急務 である。本研究では、APAP肝障害マウスモデルを用い小胞体ストレスの役割解明および小胞体ストレス 抑制薬の有效性評価を行った。

【方法】 (1) C57BL/6JjclマウスにAPAP (400 mg/kg, i.p.) を投与し作成した肝障害モデルにおいて、各種 小胞体ストレス関連因子の発現解析を行い、さらに小胞体ストレスを感知し緑色蛍光タンパク (GFP) を発するER stress activated indicator（ERAI）マウスにAPAPを投与し病理組織学的解析を行った。(2)小胞 体ストレス関連転写因子C-EBP homologous protein（CHOP）遺伝子欠損（Chop-/-）拈よび野生型（WT） マウスにAPAPを投与し、血清ALT值の測定および病理組織学的解析を行った。(3) 4-phenylbutyric acidな ど既に臨床使用されている医薬品の中で小胞体ストレス抑制作用が報告されている薬物を本マウスモデ ルに投与し、肝障害抑制効果の有無を検討した。

【結果・考察】(1)モデルマウスの肝臓においてCHOPやBimの発現立進およびc-Jun N-terminal kinase (JNK) のリン酸化が見られ、ERAIマウスにおいて肝実質細胞の障害部位特異的にGFP発現が確認された。(2) Chop-/-マウスではWTマウスと比較してAPAP投与後の血清ALT值は有意に低く、組織学的観察に抢ける 肝細胞壊死も顕著に減少した。(3) 小胞体ストレス抑制薬の投与により、APAP誘発肝障害は顕著に軽減 されたが、各薬物間で小胞体ストレス関連因子の抑制プロファイルは異なっていた。

【考察】APAP肝障害の病態形成に、小胞体ストレスが重要な役割を果たしていることが示唆された。また、 4-phenylbutyric acidなどの小胞体ストレス抑制薬は、肝障害抑制効果を持つことが示唆され、ドラッグリ ポジショニングの観点からも有益な知見であると思われる。 


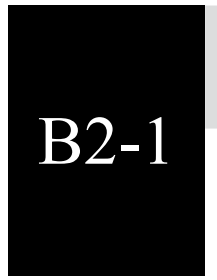

\section{前立腺肥大症に対する $\alpha_{1}$ 受容体遮断薬シロドシンの前立腺血流 を介した抑制効果}

○清水翔吾、清水孝洋、谷内恵介、東洋一郎、中村久美子、Holmstrom Felix、

齊藤源顕

(高知大 $\cdot$ 医・薬理)

【目的】高血圧や動脈硬化による前立腺血流低下は性ホルモン非依存的に増殖因子を誘導し、前立腺肥大 を惹起することを我々は報告した。さらに、前立腺肥大治療薬シロドシン（ $\alpha_{1}$ 受容体遮断薬）は自然発 症高血圧ラット（SHR）等で膀胱血流量の増加を介し、下部尿路症状を改善することを明らかにした。 本研究では前立腺肥大モデルとされるSHRを用いて、シロドシンによる前立腺血流量や細胞増殖因子へ の影響を検討した。

【方法】12週齢雄性SHRに臨床で使用されているほぼ同用量のシロドシン $100 、 300 \mu \mathrm{g} / \mathrm{kg}$ をそれぞれ6週間 連日経口投与した。また、対照としてvehicle処置のSHRと正常コントロールのWKYラット群の計4群で 実験を行った。血圧・前立腺血流量測定後、前立腺を摘出し、組織重量を測定した。その後前立腺にお ける酸化ストレスマーカー（MDA）、炎症性サイトカイン（IL-6、CINC1、TNF- $\alpha$ ）、線維化に関与する 細胞増殖因子のTGF- $\beta 1$ 及びbFGF、平滑筋アクチンである $\alpha$-SMAの蛋白レベルをELISA法及びウエスタン ブロット法にて測定した。加えて組織学的検討としてHE染色を行った。

【結果】SHRはコントロールと比較して、体重に対する前立腺重量比の増加、前立腺血流量低下、MDA、 IL-6、CINC1、TNF- $\alpha$ 、TGF- $\beta 1 、$ bFGF及び $\alpha$-SMAの発現増加がみられた。一方、シロドシン投与群にお いては、SHR群と比較して前立腺重量比には有意な差は見られなかったが、前立腺血流量、MDA、IL-6、 CINC1、TNF- $\alpha$ 、TGF- $\beta 1$ 、bFGF及び $\alpha$-SMAの発現増加を有意に軽減した。SHR群で観察された前立腺上 皮の過形成はシロドシン投与群において軽減傾向にあった。

【結語】シロドシンは前立腺血流量を増加させることで、酸化ストレスや炎症反応を軽減し、前立腺肥大 を抑制する可能性が示唆された。

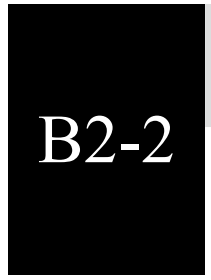

\section{虚血再灌流による腎線維化モデルにおける尿中exosomeアクア ポリン 2 タンパク質排泄量の変化についての検討}

○園田紘子 ${ }^{1}$ 、木内久な美 ${ }^{1}$ 、高橋早樹 ${ }^{1}$ 、松崎利行 ${ }^{2}$ 、池田正浩 ${ }^{1}$

('宮崎大·農・獣医薬理、群馬大院・医・生体構造)

慢性腎臓病（CKD）はタンパク尿などの腎障害の存在を示す所見、もしくは腎機能低下が3ヶ月以上 続く状態と定義されている。腎における尿濃縮に重要なタンパク質の一つに水チャネルアクアポリン 2 (AQP2) があり、AQP2は尿中の小胞、exosomeに含まれて排泄されることが明らかとなっている。CKD において腎でのAQP2発現量減少を伴って尿濃縮障害がみられることが報告されているが、これまでに CKDでの尿中exosome AQP2排泄量の変化については検討されていない。そこで今回、腎線維化における 尿中exosome AQP2タンパク質排泄量の変化について、ラットを用いて検討を行った。ラットの両腎を虚 血再灌流させることによってモデルを作製した（I/R 群）。I/R群および偽手術群（sham群）から任意の時 間に採材を行い、各種パラメータを測定した。尿中exosomeは超遠心法により分離し、AQP2タンパク質 はイムノブロット法を用いて解析を行った。腎組織は膠原線維染色によって腎線維化を評価した。sham 群と比べてI/R群では血中クレアチニン值が術後7日まで、BUN值は21日まで有意に増加した。尿浸透圧 は術後3日で有意に低下した。膠原線維染色の結果、I/R群において術後35日まで時間経過と共に腎の線 維化の進行が観察された。尿中exosome AQP2は術後3日でのみI/R群で有意に減少した。この時、腎組織 中のAQP2発現量も低下していた。AQP2はSer256およびSer269のリン酸化によってそのトラフィッキン グが制御されていると考えられている。そこで、exosomeに含まれるAQP2のリン酸化体について検討し た。その結果、どちらのリン酸化体も尿中exosome中に含まれていることが分かった。また、いずれのリ ン酸化体とも総AQP2排泄量との間に有意な正の相関関係がみられた。以上のことから AQP2は細胞膜へ のトラフィッキングに関連した過程により尿中exosomeに取り込まれること、そしてその排泄量は腎線維 化における腎AQP2の機能状態を把握する上での有用なバイオマーカーとなり得ることが考えられた。 


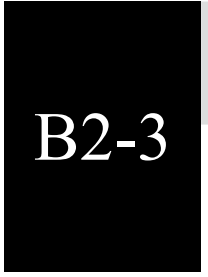

\section{慢性腎臓病における新規慢性炎症制御因子CYLDの臨床的意義} の解明

○米田 剛 ${ }^{1}$ 、末永尚輝 ${ }^{1}$ 薮内 希 ${ }^{1}$ 西 一彦 ${ }^{3}$ 齋藤秀之 ${ }^{1,2}$ 、城野博史 ${ }^{1,2}$

(熊本大 $\cdot$ 薬 $\cdot{ }^{1}$ 臨床薬物動態、熊本大病院 $\cdot{ }^{2}$ 薬剤部、 ${ }^{3}$ 血液浄化療法部)

【目的】慢性腎臓病 (CKD) は、「蛋白尿などの腎障害の存在を示す所見」もしくは「腎機能低下」が3か 月以上続く疾患であり、腎線維化を経て腎不全へと進展していく。CKDに打ける腎線維化には、様々な 環境因子や複数の原因遺伝子群の影響による慢性炎症の病態が関与している可能性が考えられているが、 その詳細な分子病態メカニズムは未だ解明されていない。本研究では、近年、線維化を抑制する機能を 有していることが明らかとなった新規慢性炎症制御因子Cylindromatosis (CYLD) に着目し、CKDの病態 におけるCYLDの臨床的意義を解明することを目的とした。

【方法】熊本大学医学部附属病院泌尿器科にて加療中の腎疾患患者のうち、インフォームドコンセントの 得られた臨床検体（線維化腎組織）を対象に、CYLD発現をタンパク質レベルで解析した。また、8週齢 C57/BL6J 雄性マウスを用いた虚血再灌流急性腎障害 (IR-AKI) モデルを対象に、腎組織中のCYLD発現と 腎機能指標 (SCr、BUN)、腎組織染色による腎障害の程度との関連について検討した。

【結果・考察】臨床検体では線維化の進行した腎病理組織において、CYLDのタンパク質レベルでの発 現が著しく低下していた。一方、IR-AKIモデルマウスでは、腎障害の進行に伴い線維化した腎組織にお いて、CYLDの発現がタンパク質レベルで低下していた。さらに、CYLDの発現低下に伴い、線維化関 連遺伝子（PAI-1, collagenなど）の発現が上昇していた。以上、本研究の検討結果より、CYLDの発現低 下を起因とした防御機構の破綻が腎線維化を誘発していることが予想され、CKDの腎線維化においても CYLDが重要な役割を果たしている可能性が示された。

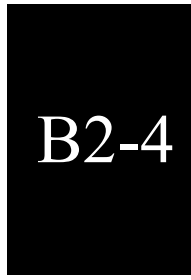

\section{GSK-3阻害薬はNF- $\kappa$ B核内移行阻害により抗炎症効果を発揮す} る

○野間俊宏 ${ }^{1,2}$ 、高橋富美 ${ }^{1}$ 、有岡将基 ${ }^{1}$ 、笹栗俊之 ${ }^{1}$

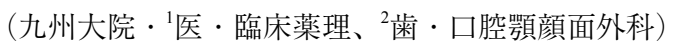

【目的】マクロファージは、炎症反応の重要なメデイエーターであるプロスタグランジン $\mathrm{E}_{2}\left(\mathrm{PGE}_{2}\right)$ を産 生する。炎症により惹起される $\mathrm{PGE}_{2}$ の合成には、2つの酵素cyclooxigenase-2（Cox-2）およびmicrosomal prostaglandin E synthase-1 (mPGES-1) が関与する。glycogen synthase kinase-3 (GSK-3) は多彩な生物学 的活性を持ち、生体において炎症反応にも関与することが示唆されているが、 $\mathrm{PGE}_{2}$ の合成における役割 は明らかにされていない。そこで我々は、ヒト急性単球性白血病細胞株THP-1を用いて、炎症における $\mathrm{PGE}_{2}$ 合成に及ぼす GSK-3阻害薬の影響を検討した。

【方法】THP-1をphorbol 12-myristate 13-acetate（PMA）によりマクロファージに分化させ、リポ多糖（LPS） により炎症反応を惹起した。GSK-3阻害薬としてLiClとSB216763を用い、Cox-2およびmPGES-1のタンパ ク質発現レベル並びにNF-KBの細胞内局在を調べた。

【結果】GSK-3阻害薬（LiClまたはSB216763）をLPSと同時に添加し、6〜48時間後に細胞を回収して解 析したところ、Cox-2も mPGES-1もタンパク質発現が抑制され、その最大効果は24時間後に認められた。 さらに、LPSを24時間前投与し十分に炎症反応を起こした後にGSK-3阻害薬と投与しても、Cox-2拉よび mPGES-1の発現は抑制された。そこで、LPS投与24時間後にGSK-3阻害薬を24時間作用させ、Cox-2およ びmPGES-1の転写因子の1つであり、炎症反応性サイトカインの重要な転写因子の1つでもあるNF-kBの 細胞内局在について調べたところ、LPS刺激はNF-kBの核内移行を促進したが、GSK-3阻害薬はこれを抑 制することが明らかとなった。

【結論】GSK-3の阻害により炎症反応に重要な役割を果たす転写因子NF-kBの核内移行が抑制され、Cox-2 と mPGES-1の発現が減少し、炎症反応が抑制されることが示唆された。このことは、新しい作用機序の 抗炎症薬としてGSK-3阻害薬を応用できる可能性を示唆している。現在、NF-kBの核内移行阻害メカニズ ムとともに、GSK-3阻害薬の生体における効果についても検討している。 


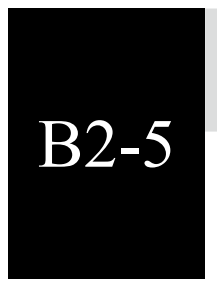

\section{ベージュマウス（Chediak-Higashi症候群動物モデル）における 巨大顆粒を有するマスト細胞の形態および機能解析}

○清井武志、劉 爽、前山一隆

(愛媛大 $\cdot$ 医·器官 $\cdot$ 形態領域 $\cdot$ 薬理)

【目的】ヒトChediak-Higashi症候群モデル動物として知られるべージュマウスの巨大顆粒を有するマスト 細胞に関する研究は、細胞移植実験にて巨大顆粒をマーカーとしてマスト細胞が骨髄由来前駆細胞より 分化することを証明した報告（北村ら 1977）が著明であるが、その生理機能についての所見を含む報告 は少ない。本研究では開口分泌過程に着目し、巨大顆粒を有するマスト細胞のヒスタミン含量とヒスタ ミン遊離率の測定、さらには脱顆粒反応時の形態変化について詳細な検討を行った。

【方法】動物はベージュマウス (C57BL/6-bg/bg) とその野生型（C57BL/6-+/t）およびへテロ型（C57BL/ 6-bg/t) を用いた。1) 形態学的解析 : 皮膚 (耳) 組織のパラフィン切片を作製し、トルイジンブルー染色後、 結合組織型マスト細胞数を計測した。大腿骨より骨髄細胞を採取後、IL-3 $(5 \mathrm{ng} / \mathrm{ml})$ 存在下で骨髄由来 培養マスト細胞（BMMC）を作製し、その形態変化をアルシアンブルー染色により検討した。走査型電 子顕微鏡（SEM）により、腹腔マスト細胞の開口分泌過程時の形態変化を観察した。2）ヒスタミン含 量およびヒスタミン遊離率の測定：皮膚 (耳、背) 組織ならびに培養BMMC中のヒスタミン含量、腹腔 マスト細胞（Compound48/80刺激）ならびに5週培養後BMMC（DNP-BSA抗原刺激）より生じるヒス夕 ミン遊離率をHPLC-蛍光法を用いて測定した。

【結果・考察】皮膚組織中の結合組織型マスト細胞数に各系統間で差を認めなかった。 $b g / b g$ マウスでは 結合組織型マス卜細胞ならびに培養BMMCの両者に巨大顆粒を認め、刺激時には開口分泌過程を経て巨 大顆粒の細胞外への放出を確認した。皮膚組織ならびに培養BMMC中のヒスタミン含量は野生型および ヘテロ型と比べて $b g / b g$ マウスで低值を示したが、刺激により生じたヒスタミン遊離率は腹腔マスト細胞 ならびに培養BMMCともに $b g / b g$ マウスで有意に増加した。またへテロ型のマスト細胞は、形態および生 理機能的に野生型と極めて近い性質を示すことが明らかとなった。

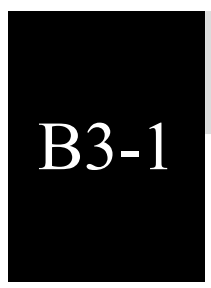

\section{単一心筋細胞レベルにおけるドキソルビシン心毒性の検討}

○早水憲吾、森本幸雄、吉原達也、笹栗俊之

(九州大院・医・臨床薬理)

【目的】アントラサイクリン系抗生物質ドキソルビシンは様々な悪性腫瘍に対して使用されている。しか し、正常組織、特に心臓に対して重篤な有害作用があるため、その使用には限界がある。ドキソルビシ ンによる心毒性は、フリーラジカル形成、アポトーシス、心筋特異的遺伝子の発現抑制、分子シグナル 経路の変化など、様々な要因が関与している可能性があるが、その正確な機序はいまだ不明である。本 研究では、野生型マウスと2型アルデヒドデヒドロゲナーゼ（ALDH2）ノックアウトマウスを用いて、 単離心筋細胞扔ける収縮機能と細胞内カルシウム濃度変化に対する影響を検討した。

【方法】8-12週齢の野生型C57BL/6およびALDH2ノックアウトマウスを用いた。ドキソルビシン $15 \mathrm{mg} / \mathrm{kg}$ を腹腔内投与した5日後に血清d-ROMsテストによる酸化ストレス評価、肺重量によるうっ血性心不全レ ベル評価、吸入麻酔下経胸壁Mモード心エコーによる心機能評価を行った。また、ドキソルビシン投与 5日後にコラゲナーゼ処理によって単離した心筋細胞にFura-2を負荷し、1 Hzの電気的刺激下でサルコメ ア短縮とで細胞内カルシウム濃度の同時測定を行った。

【結果】ドキソルビシンは、ALDH2ノックアウトマウスにおいて野生型よりも酸化ストレスを増加さ せ、うっ血性心不全の程度を悪化させた。単離心筋細胞レベルでは、ドキソルビシンは、野生型に比べ ALDH2ノックアウトマウスに扮いて収縮機能と細胞内カルシウムトランジエントをより強く傷害した。

【結論】ドキソルビシン心毒性の少なくとも一部は、細胞内カルシウム動員に関与するタンパク質の調節 機能が酸化ストレスにより障害されることによるものであり、ALDH2はそれを軽減することが示唆され た。ドキソルビシンがサルコメア蛋白質心収縮機能を直接傷害するかどうかについてはさらなる研究が 必要である。 


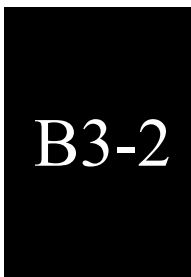

\section{禁煙補助薬バレニクリンによる心血管系有害事象}

○金岡祐輝、古賀允久、大石か扔る、杉山慶太、江島優佳、久永真美、山内淳史、

片岡泰文

(福岡大·薬・薬学疾患管理)

【背景】現在、国民の 5 人に 1 人が喫煙者である。喫煙と心疾患には密接な関係があり、禁煙することに より心疾患のリスクが軽減する。経口禁煙補助薬バレニクリンは、 $\alpha 4 \beta 2$ nicotinic acetylcholine receptor $(\mathrm{nAChR})$ 部分作動薬および $\alpha 7 \mathrm{nAChR}$ 完全作動薬であり、禁煙成功率は従来のニコチン代替療法よりも高 く、一部の心疾患患者にも使用可能である。このようにバレニクリンは画期的で有効性も高い禁煙補助 薬である。しかし、心血管イベントの危険性が増大し重篤な有害事象が発現することが報告されている。 禁煙するためにバレニクリンを服用しているにもかかわらず逆に心血管イベント発症の危険性を増大さ せるとすれば極めて問題である。しかし、その対策立案に不可欠な発症機序の解明に関する基礎研究は 殆どない。

【目的】本研究では、動脈硬化モデルマウスであるApolipoproteinE knockout (ApoE KO) マウスにバレニ クリンを投与し、その動脈硬化巣形成を評価することにより心血管イベントの発症機序を明らかにする ことを企てた。

【方法】ApoE KO マウスに8週齢時よりバレニクリンと高コレステロール食を3週間負荷した。全大動脈 をoil red-O染色し、vehicle群とバレニクリン投与群の動脈硬化巣の面積をそれぞれ測定し比較検討した。

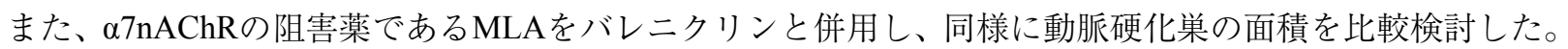
【結果・考察】ApoE KO マウスの全大動脈において、バレニクリン投与により動脈硬化巣の形成が有意 に立進した。この動脈硬化巣の増大は、MLAを併用投与すると抑制された。バレニクリンは、 $\alpha 7 \mathrm{nAChR}$ 刺激により動脈硬化巣形成を促進し、心血管イベント発症の危険性を高進させる可能性がある。

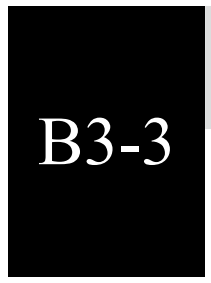

\section{家族性大腸腺腫症治療薬としての2,5-dimethyl-celecoxibの可能} 性

○西田理紗、高橋富美、江頭一成、笹栗俊之

(九州大院・医・臨床薬理)

【目的】COX-2選択的阻害薬celecoxibは、米国において家族性大腸腺腫症の治療薬として認可されてい たが、COX-2阻害に関連すると考えられる心血管障害などの重篤な副作用が問題となっている。一方、 2,5-dimethyl-celecoxib（DMC）はCOX-2阻害作用を欠くcelecoxibの類似体であり、基礎研究において種々 の腫瘍細胞に対する増殖抑制作用が報告されている。そこで、DMCの抗腫瘍薬としての可能性を検討す るため、celecoxibとDMCの抗腫瘍作用について大腸癌細胞株とMUTYH関連ポリポーシスモデルマウス を用いて比較した。

【結果】celecoxib $(100 \mu \mathrm{M})$ とDMC $(50 \mu \mathrm{M})$ は大腸癌細胞株の増殖を抑制し、Wnt $/ \beta$-cateninシグナル 経路の主要な転写因子であるT-cell factor（TCF）依存性の転写活性を低下させた。高速液体クロマトグ ラフィーを用いたマウスの血中濃度測定では、celecoxib（150 mg/ $/ \mathrm{kg}$ ) は経口投与後2時間でピーク值45 $\mu \mathrm{g} / \mathrm{ml}$ 示し、一方でDMC $(150 \mathrm{mg} / \mathrm{kg})$ は経口投与後6時間でピーク值 $72 \mu \mathrm{g} / \mathrm{ml}$ 示した。またMUTYHノッ クアウトマウスに扔いては、対照と比較しcelecoxibまたはDMCを投与した群で腸管腫瘍数が有意に抑制 された。

【結論】DMCはcelecoxibと同様に、Wnt $/ \beta$-cateninシグナル経路の抑制を介して大腸癌細胞株の増殖を抑制 することが示唆された。また、動物実験ではcelecoxibおよびDMCは経口投与により十分な血中濃度を得 ることができ、ほぼ同程度の腫瘍抑制作用を示した。これらの結果からDMCはcelecoxibと同様の効果を 示す、副作用の少ない抗腫瘍薬となる可能性が示された。 


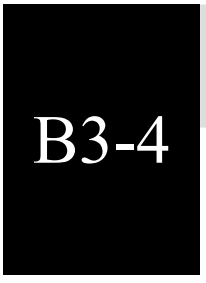

\section{マウス大腸癌肝転移モデルにおけるヒスタミンの転移抑制効果}

○倉増敦朗 ${ }^{1} 、$ 吉村 清 $^{2} 、$ 井上萌子 ${ }^{2} 、$ 玉田耕治 ${ }^{3} 、$ 田中智之 ${ }^{4} 、$ 前山一隆 5 、乾 誠 ${ }^{1}$ (山口大院・医·分子薬理、消化器・腫痬外科、免疫、岡山大院・薬・免疫生物、

愛媛大院・医・薬理 $)$

ヒスタミンは癌細胞の浸潤・遊走や血管新生の促進、免疫細胞の調節などにより癌の増殖に促進的に 働くと考えられてきたが、近年では逆にヒスタミンが癌の増殖に抑制的に働くという報告もある。我々 はマウス大腸がん肝転移モデルを用いて、大腸がん肝転移におけるヒスタミンの役割を調べた。このモ デルでは、半切した脾臓の一方より大腸癌由来CT26細胞を注入することにより、実際の大腸がん肝転移 と同様に、経門脈的に肝転移を作る。

まず、内因性ヒスタミンの役割を調べるために、野生型マウス $(\mathrm{Balb} / \mathrm{c})$ と内因性ヒスタミンを欠 如したマウスに肝転移処置を行い生存期間を比較した。内因性ヒスタミンはL-ヒスチジン脱炭酸酵素 (histidine decarboxylase; HDC) のみにより合成されるので、この酵素遺伝子の欠損マウス（hdc-/-）は内 因性ヒスタミンを欠如している。Balb/cマウスに比較してhdc-/-マウスは肝転移モデルでの生存期間が有 意に短く、内因性ヒスタミンは肝転移に対して抑制的に働いていることが示唆された。次に、局所のヒ スタミンが重要かどうかを調べるために、CT-26にHDCを強制発現させた細胞を用いて、hdc-/-マウスで 肝転移処置を行ったところ、親株の細胞を注入したマウスよりも生存期間が有意に長かった。さらに、 ハイドロダイナミックインジェクション法で、肝臓特異的にHDCを発現させると肝臓のヒスタミン含有 量が一過性に増加するとともに、肝転移モデルマウスの生存期間が延長した。

以上の結果から、マウス大腸がん肝転移モデルに拐いては、ヒスタミンは転移に対して抑制的に働く こと、そしてその効果は肝臟局所のヒスタミンによることがわかった。

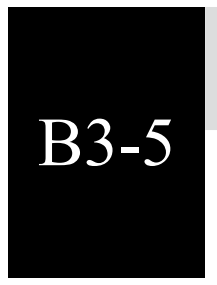

\section{完治をめざすGene Expression Programmingによる膵蔵癌の治療}

○平野英保 ${ }^{1,3}$ 、植松 稔 $^{2}$ 朝長健太 ${ }^{3} 、$ 本田勝定 ${ }^{3}$

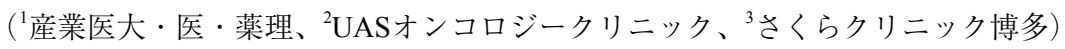

【目的・背景】膵臓癌は、手術の成功率が $15 \%$ と極めて低く、予後が悪い事が知られています。しかも、 手術が成功してからの抗癌剂の効果もうすく延命に至らない事が多い。そこで組織構築制御理論 United Gene Expression Programmingを適用する事にした。

【方法】Gene Expression Programming の、基本免疫療法（BIT）と囲い込み療法（ET）を行った後に、1 例目には、従来道理ピンポイントX-線（PPXIr）を照射した後に抗癌剤治療を行った。2例目には、PPXIr を20回照射し、空き時間带にBIT+ETを2〜3回/週行った。

【結果】1例目は、PPXIr 中の肝転移で2ヶ月後に他界。2例目は腫瘍陰影は消え生存。

【結論】膵藏癌の治療は、治療の開始から、放射線治療中にも、治療後も基本免疫療法と囲い込み療法を 行わないと完治は望めない事が判った。

【考察】1例目は基本目免疫療法と囲い込み療法に時間を掛けすぎ、点滴に飽きられてしまい、PPXIrによ る放射線治療中のBIT + ETの受け入れが出来なかった。

United Gene Expression Programming は、人の体を最高級の生物コンピューターとみなし、コマンドを ビタミンやミネラルやサプリメントや薬剤や医療技術で書いて、時間軸で実行していく技術です。

United-GEP のコマンド群 Biochemical Expression Programming, Gene Expression Programming, Medicine Expression Programming, Hormone Expression Programming, and Medical Technic を使えば、難治性の癌も 良いプログラムで治る可能性が示唆された。 


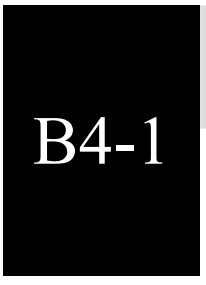

\section{マグネシウム代謝異常症の新規モデルマウスの開発}

○田頭秀章、喜多紗斗美、後藤雄輔、岩本隆宏

(福岡大·医·薬理)

マグネシウムイオン $\left(\mathrm{Mg}^{2+}\right)$ は生体機能の調節と維持に必須の2価カチオンである。実際に、 $\mathrm{Mg}^{2+}$ 欠乏 や $\mathrm{Mg}^{2+}$ 代謝異常は、高血圧症や虚血性心疾患、不整脈、胃腸疾患、骨格筋不全など、様々な疾患に関係 することが知られている。近年、 $\mathrm{Mg}^{2+}$ 輸送体の様々な分子実体（候補遺伝子）が報告されているが、そ れらの $\mathrm{Mg}^{2+}$ 制御機構、生理学的役割および病態学的意義については未だ不明な点が多い。そこで、私達

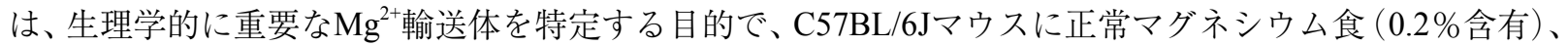
低マグネシウム食 $(0.01 \%$ 含有 $)$ もしくは高マグネシウム食 $(0.5 \%$ 含有 $)$ を4週間摂取させて、各種臓器 （大動脈、心臓、腎臓、小腸）に㧈ける $\mathrm{Mg}^{2+}$ 輸送体候補遺伝子の発現変化を調べたところ、TRPM7 $\left(\mathrm{Mg}^{2+}\right.$ 透過チャネル）と同様に、SLC41A1およびSLC41A2がマグネシウム摂取量依存性に発現変化を示すこと を見出した。これら3群のマウスでは、血中 $\mathrm{Mg}^{2+}$ 濃度および尿中 $\mathrm{Mg}^{2+}$ 排泄量がマグネシウム摂取量に相 関して有意に変動していた。また、摘出大動脈標本のフェニレフリン収縮反応を比較したところ、正常 マグネシウム食群に比べて、低マグネシウム食群で血管収縮反応の低下が観察された。次に、私達は、 SLC41A1およびSLC41A2の生体 $\mathrm{Mg}^{2+}$ 制御における機能的役割および病態学的意義を明らかにする目的 で、両者の遺伝子欠損マウスを作出することにした。得られたSLC41A1/SLC41A2ホモ欠損マウスはとも に成獣まで成長し、各種臟器で標的遺伝子を特異的に欠損していることを確認した。これらホモ欠損マ ウスは、マグネシウム摂取量依存性の血中 $\mathrm{Mg}^{2+}$ 濃度および尿中 $\mathrm{Mg}^{2+}$ 排泄量の変動が野生型マウスのそれ ら変動と明らかに異なっており、SLC41A1およびSLC41A2は生理学的に重要な $\mathrm{Mg}^{2+}$ 輸送体であることが 推定された。また、SLC41A2ホモ欠損マウス大動脈の血管収縮反応は、野生型マウスの反応に比べて減 弱していることも観察した。SLC41A1/SLC41A2ホモ欠損マウスは、 $\mathrm{Mg}^{2+}$ 輸送体のin Vivo機能解析および $\mathrm{Mg}^{2+}$ 代謝異常症の新規モデル動物として有用であると考えられる。

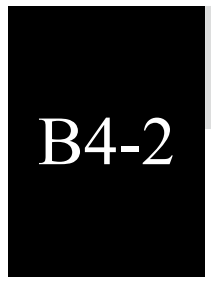

\section{心肥大時に生じるアポトーシス細胞はMFG-E8を介して除去さ れる}

○松田翔一、仲矢道雄、小宮詩織、長坂明臣、黒瀬 等

(九州大院・薬・薬効安全)

心肥大とは高血圧などの圧負荷により心臓が肥大する疾患であり、その際にはアポトーシスを起こし た細胞が増加することが知られている。しかしながら心肥大などの心疾患において生じる死細胞がどの ような分子を介して除去されるかについては、未だほとんど明らかではない。そこで我々は死細胞の除 去に関与することで知られるMilk Fat Globule Epidermal Growth Factor 8（MFG-E8）という分泌タンパク 質に着目した。MFG-E8とはアポトーシス細胞の表面に露出されるホスファチジルセリンと領食細胞表面 のインテグリン $\alpha \mathrm{v} \beta 3$ の両方に結合して、死細胞の食食を促進する分子である。すなわち、本研究では心 肥大時におけるMFG-E8の役割を解明する事を目的とした。

6〜8週齢の雄性C57BL/6J野生型（WT） マウス抢よびMFG-E8ノックアウト（KO）マウスに対して心 蔵の大動脈弓を狭窄するTAC (Transverse Aortic Constriction) 処置を行い、心肥大モデルマウスを作製し た。まずTAC処置を施したWTマウスの心臓におけるMFG-E8の発現を調べたところ、処置後1週目をピー クにMFG-E8の発現量の顕著な増加が認められた。そこで次にMFG-E8の産生細胞について検討を行った。 その結果、心肥大時にコラーゲン等の細胞外マトリックスを産生して心臓の線維化を担う筋線維芽細胞 がMFG-E8を産生することを見出した。これまで筋線維芽細胞が死細胞を食食するという報告はされて いない。しかし、MFG-E8を発現していた事から筋線維芽細胞が領食能を持つかについて検討したとこ ろ、筋線維芽細胞がインテグリン $\alpha \mathrm{v} \beta 3$ を発現し、MFG-E8を介して死細胞を領食することを新たに見出 した。実際にTAC処置後のMFG-E8 KOマウスの心臓ではWTマウスに比べ、アポトーシス細胞の残存が 多く認められた。さらにMFG-E8 KOマウスではWTマウスに比べてTAC処置後の心臓の肥大や線維化の 増強が認められ、それに伴い心臓の機能や生存率もWTに比べ顕著に低下していた。本研究の結果から、 MFG-E8は筋線維芽細胞による死細胞の領食除去を介して、心肥大時に心保護的に働く因子であることが 示唆された。 


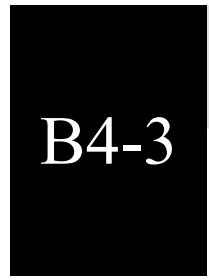

\section{進行性心不全を呈する遺伝性拡張型心筋症マウスにおけるピモ ベンダンのステージ依存性ベネフィットとリスク}

○野中美希 ${ }^{1}$ 、森本幸生 ${ }^{1}$ 、村山 尚 ${ }^{2}$ 、吳林なごみ ${ }^{2}$ 、有岡将基 ${ }^{1} 、$ 吉原達也 ${ }^{1}$ 、高橋富美 ${ }^{1,3}$ 、 笹栗俊之 ${ }^{1}$

( ${ }^{1}$ 九州大院 ·医 $\cdot$ 臨床薬理、 ${ }^{2}$ 順天堂大 $\cdot$ 医 $\cdot$ 薬理、 ${ }^{3}$ 九州大院 $\cdot$ 医 $\cdot$ 医学教育学部門)

【目的】 $\mathrm{Ca}^{2+}$ 感受性増強薬ピモベンダンは、従来の強心薬のように酸素消費を大きく増加させることなく 心筋収縮力を改善することができることから、心筋リモデリングと不整脈に対する有害作用をあまり持 たないと期待されたユニークな強心薬である。しかし、臨床試験では、心不全患者において期待に反す る結果も報告されている。我々は、進行性心不全を呈する新規モデルマウスを用いて、作用機序に基づ いたピモベンダンの有効性に関する実験的証拠を得ることを試みた。

【方法】成長のある時点において代償期から末期心不全へと明確な移行を示す七ト遺伝性拡張型心筋症モ デルマウスを用いてピモベンダンの有効性を評価し、背後にある分子小よび細胞メカニズムを探った。

【結果】ピモベンダンは代償期心不全の心筋リモデリングを抑制し、代償期と末期心不全に抢ける生存期 間を有意に延長したが、末期心不全における突然死を用量依存的に増加した。末期心不全マウスから単 離した心筋細胞において、ピモベンダンは著しくアップレギュレートされた起電性 $\mathrm{Na}^{+} / \mathrm{Ca}^{2+}$ exchanger 1

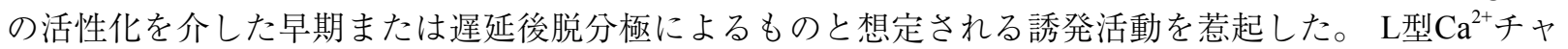
ネルブロッカーであるべラパミルにより誘発活動が減少することから、末期心不全においては筋小胞体 $\mathrm{Ca}^{2+}$ 取り込み能低下と $\mathrm{Ca}^{2+} リ ー ク$ 増加のためにPDE3阻害作用による $\mathrm{Ca}^{2+}$ 流入増加によって細胞質 $\mathrm{Ca}^{2+}$ が著 しく上昇しやすいことがこれに関与していることが示唆された。

【結論】ピモベンダンは心不全のステージによらず有益であるが、 $\mathrm{Ca}^{2+}$ ハンドリングの広範なリモデリン グを生じている末期心不全においては心臓突然死を増加させる。PDE3阻害作用による過度の細胞質 $\mathrm{Ca}^{2+}$ 上昇を抑制することによって、心蔵突然死のリスクを低減できるかもしれない。

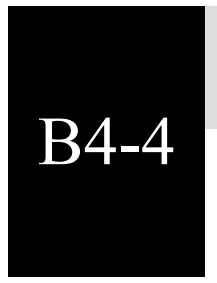

\section{実験に資する急性心筋梗塞モデルの開発：2/3腎摘トリプル一} 酸化窒素合成酵素欠損マウス

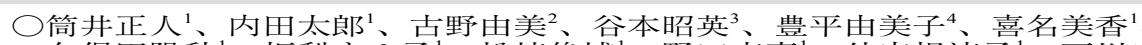

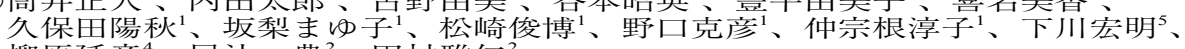

柳原延章 ${ }^{4}$ 尾辻 豊 ${ }^{2}$ 、田村雅仁

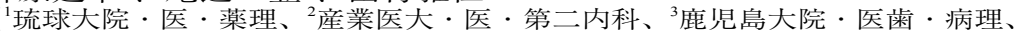

産業医大・医・薬理、涷北大院・医 $\cdot$ 循環器内科)

【背景と目的】急性心筋梗塞（AMI）は日本人の主要な死因の一つである。AMIは突然死を来すことから、 発症予防が極めて重要である。しかし、実験に有用なAMIを発症するモデルが全く無いために、その予 防戦略の研究開発は遅々として進んでいない。この点を検討するために、我々は、一酸化窒素合成酵素 完全欠損マウス（triple $\mathrm{n} / \mathrm{i} / \mathrm{eNOSs}^{-/}$ママウス）に㧍ける腎臓亜全摘の効果を検討した。

【方法と結果】オスのtriple NOSs ${ }^{-1}$ マウスに $2 / 3$ 腎臓摘除術（NX）を施行した。2/3NX triple NOSs ${ }^{-/}$マウス は、術後4ヶ月以内の早期にAMIを発症し突然死した。術後2ヶ月の $2 / 3 \mathrm{NX}$ triple $\mathrm{NOSs}^{-/}$マウスには、心 電図のST上昇、Heart rate variabilityの低下、心エコーでの局所壁運動異常、及び高度の冠動脈硬化病変 形成が認められた。機序の検討では、心血管危険因子（高血圧、高脂血症、高血糖）の増悪および循環 血中骨髄由来血管平滑筋前駆細胞数（動脈硬化促進因子）の増加が認められた。さらに、血漿アンジオ テンシンIIレベルの増加抢よび尿中 8 -イソプロスタンレベル（酸化ストレスの指標）の増加が観察され た。重要なことに、臨床用量のアンジオテンシンII1型受容体拮抗薬irbesartan及びカルシウムチャネル拮 抗薬amlodipineの併用投与は、上記異常所見をすべて有意に改善し、AMIの発症を有意に予防し、予後を 有意に改善させた。

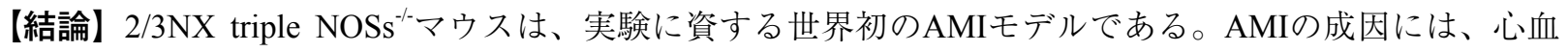
管危険因子、骨髄由来血管平滑筋前駆細胞、レニンーアンジオテンシン系活性化、および酸化ストレス が関与していることが示唆された。(J Mol Cell Cardiol 2014, in press) 


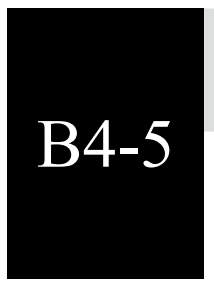

\section{内皮由来物質による血管平滑筋の組織様構築及び収縮能の形成}

○大池正宏、木村千稚

(九州大院・医・生体情報薬理 $)$

【背景・目的】血管内皮細胞が血流や自律神経刺激等に反応して各種の血管収縮物質及び弛緩物質を分泌 することは広く知られている。血管内皮細胞はまた増殖因子を分泌して血管平滑筋の増殖にも影響して いる。我々は、血管内皮細胞が恒常的に分泌する物質が血管の組織構築と収縮能の形成に影響する可能 性について検討した。

【方法】実験にはウシ大動脈内皮細胞（BAEC）とウシ大動脈平滑筋細胞（BASMC）を培養して使用した。 BASMCの収縮能は I 型コラーゲンに包埋培養してゲル収縮アッセイで検討した。BASMC包埋ゲルの収 縮に及ぼす内皮由来物質の効果は、これにBAECを重層培養またはその培養上清存在下で培養して検討 した。細胞内 $\mathrm{Ca}^{2+}$ 濃度 $\left(\left[\mathrm{Ca}^{2+}\right]_{\mathrm{i}}\right)$ の測定にはfura2を、蛋白発現の解析にはWestern blottingを使用し、アク チン細胞骨格はphalloidinで染色した。また、ゲル内の細胞形態観察にはcalcein蛍光を使用した。

【結果】BASMC包埋ゲルはATP $(10 \mu \mathrm{M})$ 及び $59 \mathrm{mM} \mathrm{KCl}$ 溶液によって収縮した。BAECの重層またはそ の培養上清下で培養したBASMC包埋ゲルの収縮は、培養2日後には対照ゲルと差がなかったのに対し、 培養5日後には有意に増大した。このとき、ゲル内のBASMCは著しく伸張して相互に結合し、血管組 織様の構築を形成していた。このアゴニスト収縮の増大はindomethacin及びET受容体阻害薬（BQ123、 BQ788）によって阻害されず、TGF $\beta$ 受容体阻害薬（SB431542）によって抑制された。一方、BASMC の平滑筋マーカー (SM actin、myosin、calponin) の発現は内皮上清によって変化せず、また $\left[\mathrm{Ca}^{2+}\right]_{\text {変化 }}$

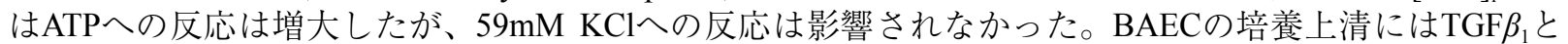
$\mathrm{TGF} \beta_{2}$ が含まれており、上清によるBASMCゲルの収縮増大と細胞形態変化はTGF $\beta_{1}$ 中和抗体と TGF $\beta_{2}$ 中和 抗体の共存下で完全に抑制された。

【考察】血管内皮細胞はTGF $\beta_{1}$ とTGF $\beta_{2}$ を恒常的に分泌しており、これらが血管平滑筋の組織様構築の形 成を促進維持することで血管収縮能に影響することが示唆された。

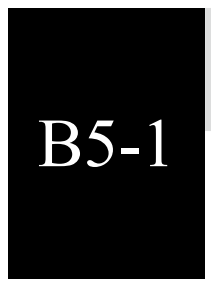

\section{心肥大および心血管死におけるNOの役割：マウスおよびヒト における検討}

○筒井正人 1 、龟崎文彦 2,3 、真弓俊彦 ${ }^{3}$ 、尾辻 豊 $^{2}$

('琉球大院・医・薬理、産業医大・医・第二内科、躈急医学)

一酸化窒素(NO)は、3つのNO合成酵素アイソフォーム（nNOS、iNOS、eNOS）から産生される。ヒト 心臓には、生理的条件下で、全てのNOSsが発現している。我々は過去に、全てNOSsを欠損させたマウ スが、左室肥大および心血管死を引き起こすことを明らかにした（Circulation 2008、Circ J 2010）。最近、 高血圧者のみならず正常血圧者においても、心電図左室肥大が将来の心血管死のリスクファクターであ ることが報告された (Hypertension 2009)。しかし、その機序は不明である。我々は、自身のマウス研究 の成果を踏まえて、『心電図左室肥大を有する正常血圧者における心血管死リスクの増加には、NO産生 低下が関与している』と仮説を立てた。この仮説を検証するために、579名の正常血圧男性労働者にお いて、心電図左室肥大を有する73名 (左室肥大群) と、年齢、ウエス卜周囲径、収縮期血圧、拡張期血 圧に関して1対1傾向スコアマッチングした73名（対照群）を検討した。左室肥大群における血漿NOxレ ベルは、対照群に比して有意に低下していた $(P<0.05)$ 。左室肥大に対するオッズ比は、血漿NOxレベ ルの第3三分位群 $(41.8 \mu \mathrm{mol} / 1$ 以上 $)$ と比較して、第1三分位群 $(21.2 \mu \mathrm{mol} / 1$ 以下 $)$ で4.98 $(P<0.05)$ 、第2 三分位群 $(21.2 \sim 41.8 \mu \mathrm{mol} / 1)$ で1.99（P=0.10）であった。酸化ストレスの指標である血漿8-isoprostaneレ ベルは、対照群に比して左室肥大群で有意に増加していた $(P<0.05)$ 。以上 本研究では、心電図左室肥 大を有する正常血圧者において、血漿NOxレベルが有意に低下し、血漿8-isoprostaneレベルが有意に増加 していることを明らかにした。これらの結果から、心電図左室肥大を有する正常血圧者における心血管 死リスクの増加には、NO産生低下並びに酸化ストレスが関与していることが示唆された (Hypertension 2014; 64: 516-522)。 


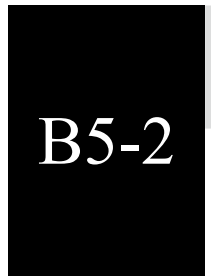

\section{食事中の亜硝酸 $\left(\mathrm{NO}_{2}^{-}\right)$/ 硝酸 $\left(\mathrm{NO}_{3}^{-}\right)$の不足はマウスにメタボ リックシンドローム様の病態を惹起する}

○筒井正人、喜名美香、坂梨まゆ子、松崎俊博、野口克彦

(琉球大院・医・薬理)

【目的】一酸化窒素 $(\mathrm{NO})$ は代謝系の恒常性の維持に重要な役割を果たしている。最近、NOの代謝物で ある亜硝酸 $\left(\mathrm{NO}_{2}^{-}\right)$㧍よび硝酸 $\left(\mathrm{NO}_{3}^{-}\right)$から $\mathrm{NO}$ が産生される経路が発見された。本研究では、食事中の $\mathrm{NO}_{2}{ }^{-}$ $\mathrm{NO}_{3}$ の不足がメタボリックシンドロームを惹起すると仮説を立て、それをマウスにおいて検討した。

【方法】通常食と、脂肪・炭水化物・蛋白質含有量、カロリー、およびL-アルギニン含有量が全く同一の 低 $\mathrm{NO}_{2}{ }^{-} / \mathrm{NO}_{3}{ }^{-}$食を準備した。生後6週齢のオスの野生型C57BL/6Jマウスに、低 $\mathrm{NO}_{2}{ }^{-} / \mathrm{NO}_{3}{ }^{-1}$ 食および普通食を 12週間投与した $(\mathrm{n}=6 \sim 12)$ 。

【結果】血漿 $\mathrm{NO}_{2}^{-} / \mathrm{NO}_{3}^{-}(\mathrm{NOx})$ レベルは、普通食群に比して低 $\mathrm{NO}_{2} / \mathrm{NO}_{3}^{-}$食群で著明に低下していた。食 餌摂取量、摂取カロリー量、および体重は、低 $\mathrm{NO}_{2}^{-} / \mathrm{NO}_{3}^{-}$食群と普通食群で差が無かった。しかし、低 $\mathrm{NO}_{2}{ }^{-} / \mathrm{NO}_{3}^{-}$食群では普通食群に比し、内臓脂肪量および血漿総コレステロール值が有意に増加し、有意な 耐糖能異常が認められた。さらに、低NOx食群では普通食群に比し、血漿アディポネクチン值が有意に 低下していた。

【結論】食事中の $\mathrm{NO}_{2}$ // $\mathrm{NO}_{3}^{-}$の不足がメタボリックシンドローム様の病態を惹起することを明らかにした。 この知見は、カロリー過多がなくてもメタボリックシンドロームを惹起する食事成分を初めて特定した 点に学術的意義があると考えられた。(平成26年12月 特許出願)

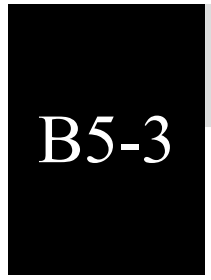

\section{高カルシウム血症時における $\mathrm{Na}^{+} / \mathrm{Ca}^{2+}$ 交換輸送体の機能的役割} の検討

○後藤雄輔、喜多紗斗美、田頭秀章、岩本隆宏

(福岡大·医・薬理)

$\mathrm{Na}^{+} / \mathrm{Ca}^{2+}$ 交換輸送体（NCX）は $3 \mathrm{Na}^{+}$と $1 \mathrm{Ca}^{2+}$ を交換する膜輸送体であり、腎臓にはNCX1と NCX2の2種 のアイソフォームが発現している。私達は、尿生成およびCa ${ }^{2+}$ 排泄におけるNCX1/NCX2の各機能的役割 について、特異的NCX阻害薬およびNCX1/NCX2へテロ欠損マウスを用いた検討を行ってきた。これまで に、NCX2の機能抑制により $\mathrm{Na}^{+}$利尿およびCa ${ }^{2+}$ 排泄促進が引き起こされること、また、NCX1の機能抑制 によっても同様の効果が観察されるが、その効果は軽度であることを明らかにしてきた。

今回、 $\mathrm{Ca}^{2+}$ 代謝異常時のNCXアイソフォームの機能的役割を解析するため、ビタミン D 誘発高カルシウ ム血症モデルマウス（コレカルシフェロールの3日間処置）に対するNCX阻害薬の影響を調べた。まず、 正常なC57BL/6Jマウスに対して、NCX阻害薬（YM-244769、KB-R7943）は用量依存的に尿量、電解質 排泄（ $\left.\mathrm{Na}^{+}, \mathrm{K}^{+}, \mathrm{Cl}^{-}\right)$および $\mathrm{Ca}^{2+}$ 排泄を有意に増大させたが、血中 $\mathrm{Ca}^{2+}$ 濃度には有意な影響を与えなかった。 一方、ビタミン D誘発高カルシウム血症モデルマウスでは、血中 $\mathrm{Ca}^{2+}$ 濃度の増加とともに尿中 $\mathrm{Ca}^{2+}$ 排泄が 充進したが、このマウスにNCX阻害薬を投与すると、予想に反して、高カルシウム血症の悪化が認めら れた（血中 $\mathrm{Ca}^{2+}$ 濃度のさらなる増加）。この時、重篤な体重減少を呈するマウスでは死亡例も観察された。 次に、正常なNCX1/NCX2へテロ欠損マウス間での腎機能を比較したところ、NCX2へテロ欠損マウスで は、野生型マウスに比べて、尿量、電解質排泄および $\mathrm{Ca}^{2+}$ 排泄の有意な光進が認められ、NCX1へテロ欠 損マウスにおいても軽度であるが、同様の機能立進が観察された。そこで、NCX1/NCX2へテロ欠損マウ スを用いてビタミン D誘発高カルシウム血症モデルを作製したところ、血中 $\mathrm{Ca}^{2+}$ 濃度の増加は両へテロ 久損マウスともに野生型マウスとほぼ同程度であった。これらの結果は、正常時と高カルシウム血症の 病態時において、NCXアイソフォームの機能的役割が異なっている可能性を示唆している。現在、この 機能的差異の機序について検討を進めている。 


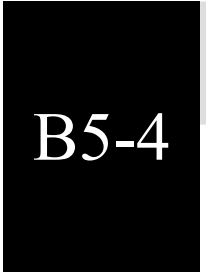

\section{ホスホランバンアプタマーによる心筋収縮能およびCa ${ }^{2+}$ トラン ジェントの増強作用}

○酒井大樹 ${ }^{1}$ 、池田安宏 ${ }^{2} 、$ 本田 健 $^{1} 、$ 田中貴絵 ${ }^{1}$ 、白石宏造 ${ }^{2} 、$ 幹 誠 ${ }^{1}$

(山口大院·医·分子薬理、㗊官病態内科)

【緒言】心筋細胞の収縮・弛緩の制御は、細胞内 $\mathrm{Ca}^{2+}$ 貯蔵部位である心筋細胞が主要な役割を果たす。 この心筋小胞体への $\mathrm{Ca}^{2+}$ 輸送は、 $\mathrm{Ca}^{2+}$ ポンプ蛋白質であるsarco/endoplasmic reticulum $\mathrm{Ca}^{2+}$-ATPase $2 \mathrm{a}$ (SERCA2a) が担い、もう1つの心筋小胞体膜蛋白質であるホスホランバン（PLN）がこれを抑制的に調 節している。心不全では、心筋小胞体のC $\mathrm{Ca}^{2+}$ 輸送能が低下し、PLNによるSERCA2a抑制が増強すること が知られ、PLNは心不全治療の格好の薬物標的であると注目されている。本研究では、PLNに特異的に 結合するRNAアプタマーを見出し、心筋小胞体でのSERCA2a-PLN系への効果を調べると共に細胞内への

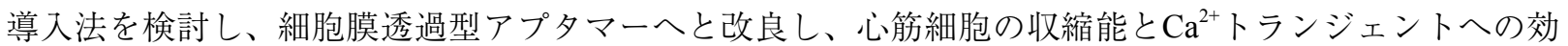
果を解析した。

【方法・結果】PLNの細胞質ドメインの融合蛋白質と40 merのランダム配列を含むRNAライブラリーを用 いて、SELEX法によりPLNに対するRNAアプタマーを得た。このうちのRNA-Apt30は、PLNに対し高親 和性の結合能 $(\mathrm{Kd}=11 \mathrm{nM})$ を示し、心筋小胞体のSERCA2a活性を増強した。この際のEC 保 $_{\text {は、 }} 18 \mathrm{nM}$ であった。さらに、このアプタマーを細胞内へ導入するために、細胞膜透過性ペプチドとして改変型 TATペプチドを付加したmTAT-RNA-Apt30を合成した。このアプタマーは、成獣ラットより単離した心筋

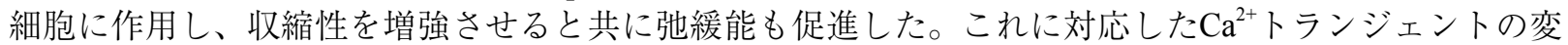
化、即ち最大 $\mathrm{Ca}^{2+}$ 濃度の増加並びに $\mathrm{Ca}^{2+}$ 濃度低下の時定数の短縮も認められた。さらに、カフェインを用 いた心筋小胞体内のCa ${ }^{2+}$ 量の評価から、mTAT-RNA-Apt30による心筋小胞体 $\mathrm{Ca}^{2+}$ 輸送の充進が確認された。 【考察】以上の結果より、mTAT-RNA-Apt30は心筋細胞の収縮性の増強と共に弛緩能の促進をもたらすこ とが明らかとなり、新たな心不全治療薬としての可能性が示唆された。

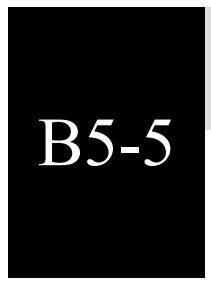

\section{筋芽細胞株の分化制御におけるPDZRN3蛋白質の役割}

○本田健、仲田成美、永井涼人、乾誠

(山口大院・医·分子薬理)

【諸言】PDZRN (PDZ domain containing RING finger) 3は、2つのPDZドメインおよびPDZ結合モチーフ を持ったRING型E3ユビキチンリガーゼであり、主に心臓や骨格筋に分布する蛋白質である。また間葉 系前駆細胞に多く発現することから、我々はこれらの細胞分化におけるPDZRN3の役割について解析し てきた。その結果、骨細胞や脂肪細胞分化ではPDZRN3は抑制的に働き、筋分化では必須因子であるこ とが明らかとなった。筋芽細胞株C2C12を用いた筋分化では、PDZRN3の発現抑制によって筋分化マー カーであるミオシン重鎖（MHC）蛋白質の発現が抑制されるが、その分子機構の詳細は未だ不明である。 MHC発現を誘導する主要な転写因子はmyogeninであるが、PDZRN3の発現抑制によってmyogeninの発現 量に明らかな変化は認められない。そこで我々は、myogeninに結合して転写活性を阻害するId2に着目し、 PDZRN3の筋分化制御におけるId2の関与について検討した。

【方法・結果】MHC上流プロモーターを用いたレポーターアッセイを行ったところ、対照細胞に比べて PDZRN3発現抑制細胞では、筋分化刺激に応じたプロモーター活性の増加が見られず、 myogeninの発現 量に明らかな変化はないが転写活性が減少していることを見出した。その転写活性の減少に対するId2の 関与を調べるために、C2C12細胞の筋分化過程におけるId2発現量を解析した。通常、筋分化の進行に伴 いId2の発現は著明に抑制されるが、PDZRN3発現を抑制した細胞では、対象細胞に比べてId2の発現量が 増加していた。PDZRN3発現抑制細胞にsiRNAを導入してId2の発現増加を抑えると、筋分化刺激による MHCの発現誘導が回復した。

【考察】以上の結果は、PDZRN3発現抑制によって起こるMHC発現誘導の阻害はId2の発現増加に起因す ることを示唆する。即ち、筋分化に際してPDZRN3は、myogenin阻害因子であるId2の発現抑制に関与し て筋分化を促進していると考えられる。 


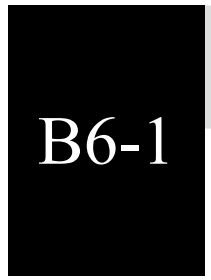

\section{貯蔵部作動性 $\mathrm{Ca}^{2+}$ 流入持続相におけるSTIM1リン酸化反応の役 割}

$\bigcirc$ 平野勝也 ${ }^{1}$ 、花田亜希子 ${ }^{2}$ 、平野真弓 ${ }^{2}$

( ${ }^{1}$ 香川大・医・自律機能生理、 ${ }^{2}$ 九州大院・医・分子細胞情報)

【目的】細胞内 $\mathrm{Ca}^{2+}$ 貯蔵部の貯蔵 $\mathrm{Ca}^{2+}$ 量の低下によってSTIM1が活性化され、貯蔵部作動性 $\mathrm{Ca}^{2+}$ 流入が活性 化される。STIM1はリン酸化されることが報告されている。本研究では、貯蔵部作動性 $\mathrm{Ca}^{2+}$ 流入機構に おけるSTIM1リン酸化の役割を明らかにする。

【方法】ブタ大動脈内皮細胞（PAEC）およびHeLa細胞を用いた。Fura-2蛍光測定法により $\left[\mathrm{Ca}^{2+}\right]_{\text {変化を記 }}$ 録した。Phos-tag SDS-PAGE法によりSTIM1リン酸化を解析した。種々の領域を欠損するSTIM変異体を 用いてリン酸化領域を決定した。仮想的リン酸化部位に変異のあるSTIM1を発現するHeLa細胞の安定株 を確立し、 $\mathrm{Ca}^{2+}$ 反応を解析した。

【結果】PAECおよびHeLa細胞のいずれにおいても、細胞外 $\mathrm{Ca}^{2+}$ を除去し、タプシガルギンにより貯蔵部

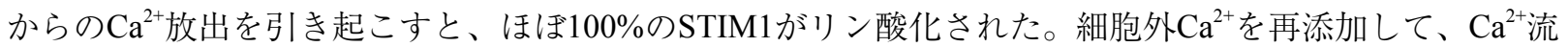
入を引き起こしてもSTIM1のリン酸化は持続した。PAECにおいてトロンビンにより引き起こされた $\mathrm{Ca}^{2+}$ 放出に伴い、STIM1はリン酸化された。この場合、細胞外 $\mathrm{Ca}^{2+}$ の再添加によりSTIM1はトロンビン刺激前 のレベルまで脱リン酸化された。ML-9およびワルトマニンは、タプシガルギンが引き起こすSTIM1のリ ン酸化と $\mathrm{Ca}^{2+}$ 流入の持続相を抑制した。タプシガルギンによるSTIM1のリン酸化は、C末端領域40アミノ 酸を欠損させると消失した。この領域には3残基のSer、1残基のThrが含まれる。これらすべてをAlaに置 換すると、タプシガルギンによる $\mathrm{Ca}^{2+}$ 流入の持続相が抑制された。4残基の内1残基でもリン酸化される アミノ酸に残しておくと、 $\mathrm{Ca}^{2+}$ 流入の抑制は認められなかった。

【結論】貯蔵 $\mathrm{Ca}^{2+}$ 量の低下に依存してSTIM1は、そのC末端領域にリン酸化を受ける。このリン酸化は貯 蔵部 $\mathrm{Ca}^{2+}$ 流入の維持に関わる。 $\mathrm{Ca}^{2+}$ 流入の維持には、4残基の内1残基のリン酸化で十分である。

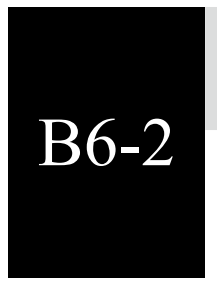

\section{大伏在静脈瘤の発症には血管平滑筋の張力低下が関与する}

○蒲生修治 ${ }^{1} 、$ 横田敦子 ${ }^{2} 、$ 鳥取部直子 ${ }^{1} 、$ 中村栄作 ${ }^{3} 、$ 桑原正知 ${ }^{4} 、$ 浅田祐士郎 ${ }^{5} 、$

山下 䇫、山本隆一

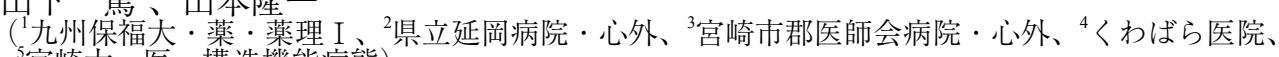

宮崎大・医・構造機能病態)

【背景・目的】大伏在静脈は、静脈瘤を発症しやすいことが知られているが、詳しい発症メカニズムは不 明である。演者らの研究室では、冠動脈バイパス手術のグラフト用に摘出された大伏在静脈のうち手術 に使用しなかった部分や、大伏在静脈瘤の治療のために抜去された血管を、書面による患者の同意を得 て研究用サンプルとして提供を受けている。本研究では、大伏在静脈瘤の発症メカニズムを解明するた めに、静脈瘤の膨隆の度合いと血管平滑筋の張力との関連性について検討した。

【方法】大伏在静脈瘤患者から摘出された血管をオルガンバスに懸垂後、2 $\mathrm{g}$ の静止張力をかけた状態で

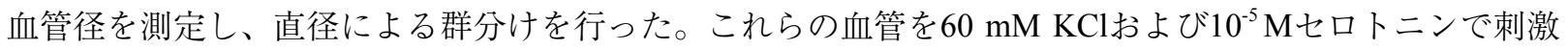
し、発生する収縮張力を等尺性に測定して、血管径と収縮張力との関連性を検討した。対照となる正常 血管には、冠動脈バイパス手術のグラフトとして摘出された血管のうち、手術に使用しなかった部分を 用いた。血管をホルマリンで固定した後に凍結切片とし、ヘマトキシリン・エオジン染色した後に、血 管組織の病理学的観察を行った。

【結果】静脈瘤患者の大伏在静脈（varicose vein, VV) では、血管周囲長あたりの収縮張力が、KCl刺激、 セロトニン刺激ともに正常血管と比較して有意に低下していた。ただし血管径 $6.1 \mathrm{~mm}$ までのVVでは群間 差が認められなかった。高度に拡張したVV（血管径 $6.1 \mathrm{~mm}$ 超）では、径あたりの収縮力が有意に減弱し ていた。組織像は、高度に拡張したVVでは、中膜平滑筋の萎縮や線維化がみられたが、正常血管と同程 度の径 (1.3-2.5 mm)のVVは異常が見られなかった。これらの結果から、大伏在静脈瘤の発症においては、 組織学的変化に先立って平滑筋収縮力の低下が生じ、これが惹起因子となって血管膨隆が始まる可能性 が示唆された。 


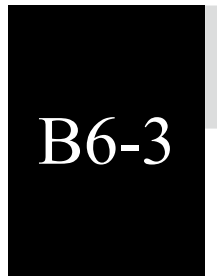

\section{内皮バリアー障害の初期事象としての細胞辺縁部のミオシン軽 鎖 2 リン酸化とアクチン線維束形成の役割}

○平野真弓 ${ }^{1}$ 、平野勝也 ${ }^{2}$

$\left({ }^{1}\right.$ 九州大院 ·医 · 分子細胞情報、香川大 ·医 · 自律機能生理 $)$

【目的】ミオシン軽鎖（MLC）リン酸化とアクチン線維束形成は内皮細胞収縮を引き起こし、バリアー 障害に重要な役割を果たす。本研究は、MLCの1リン酸化（pMLC）と2リン酸化（ppMLC）の機能的違 いを明らかにする。

【方法】ブタ大動脈内皮細胞を用いた。経内皮細胞電気抵抗（TEER）測定により内皮バリアー機能を評 価した。Phos-tag SDS-PAGE法によりMLCリン酸化を定量解析した。pMLC、ppMLC、アクチン線維の局 在を、共焦点蛍光顕微鏡を用いて観察した。リン酸化部位（T18、S19）をAに置換したMLC変異体を、 アデノウイルスを用いて発現させた。

【結果】トロンビン（1 unit/ml）は、刺激3-5分後に最大に達するTEERの低下を引き起こした。pMLCは 刺激前值 $25 \%$ から刺激 1 分後にわずか上昇した。一方、ppMLCは $2 \%$ から $35 \%$ に昇した。 pMLCは刺激 前から細胞質に局在が観察され、この局在は刺激3分後も変動しなかった。ppMLCは刺激前観察されな かったが、刺激3分後は細胞辺縁部に認められた。この局在に一致してアクチン線維束の形成が認められ た。その後、ppMLCは漸減したが、pMLCは一旦低下した後、刺激15分後から再上昇が認められ、この 時アクチン線維はストレスファイバーを形成した。Rhoキナーゼ阻害剂Y27632 およびH1152は、刺激3分 後の細胞辺縁部のppMLCとアクチン線維束形成、刺激15分後のpMLC、TEER低下を阻害した。ミオシン ATPase阻害剤blebbistatinは、MLCリン酸化に影響を与えず、TEER低下を抑制した。T18A+S19A変異体を 発現する内皮細胞ではトロンビンによるバリアー障害が抑制された。T18AあるいはS19Aの単独の変異体 は野生型と同様のバリアー障害を引き起こした。

【結論】pMLCとppMLCは異なる制御を受ける。細胞辺縁部におけるppMLCがアクチン線維束形成と細胞 収縮を引き起こし、バリアー障害の初期に重要な役割を果たす。

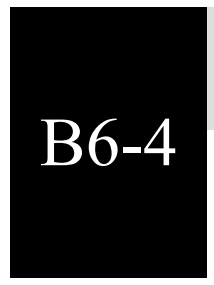

\section{血管傷害モデルに伴う血管リモデリング形成に対する骨髄由来 細胞のHIF-1 $\alpha$ の関与 \\ $\bigcirc$ 今西正樹 ${ }^{1}$ 、村上正樹 ${ }^{2} 、$ 前田悠作 ${ }^{3}$ 、冨田紀子 ${ }^{1,4}$ 、Panagiota Tsounapi ${ }^{5}$ 、 \\ 松永慎司 ${ }^{1}$ 、玉置俊晃 ${ }^{3} 、$ 富田修平

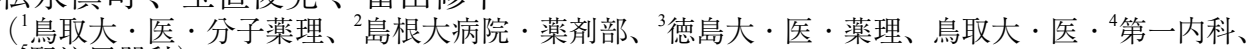 \\ 腎泌尿器科)}

【背景】最近、種々の増殖因子やサイトカインが、血管平滑筋において低酸素応答性転写因子HIFを活性 化することが明らかにされている。また、HIFは、細胞内エネルギー代謝を司り、細胞の分化・増殖に関 与していることが報告されている。そこで、動脈傷害に伴う血管リモデリングの病態形成およびその進 展過程に血管平滑筋のHIFが関与するかどうか検討することにした。

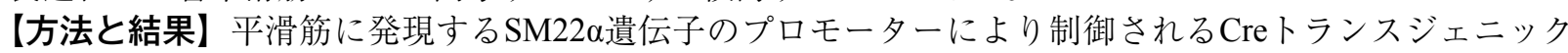
(Tg)マウスとの交配作製によるHIF-1 ワイヤーを用いた大腿動脈傷害モデルを作製した。傷害後4週では、対照群（WT）に比較してCKOにお いて、新生内膜と中膜肥厚の軽減が認められた。CKO由来の骨髄で置換した骨䯣キメラマウス（CKO $\rightarrow$ WT)においても同様の表現型の軽減が認められた。しかし、WT由来の骨髄で置換したキメラマウス（WT $\rightarrow$ CKO）では、そのような変化は観られなかった。更に骨髄細胞におけるHIF欠失の影響を検討するた めに、WTあるいはCKOと、テスターマウス（CAGプロモーターの下流にEGFP遺伝子を連結し、その間 にstop配列としてloxPで挟まれたCAT遺伝子を挿入してあるレポーター遺伝子をもつTgマウス）との交配 により、2種類のマウスWT-EGFPあるいはCKO-EGFPを作製した。各マウスの骨髄細胞に置換したそれ ぞれのC57BL/6キメラマウスを作製し、血管傷害モデルの組織学的評価を行った。傷害部位動員される EGFP陽性細胞数はWT-EGFPの骨髄に置換したキメラマウスよりもCKO-EGFPの骨髄に置換したキメラマ ウスの方が少ないことが分かった。

【考案と結語】以上の結果は、本変異マウスにおいて観られる血管リモデリングの軽減には、骨髄由来細 胞中でHIFが欠失した細胞集団の傷害部位への動員数減少が関与していることを示唆している。今後血管 リモデリングの機序を解明する上で、これらの細胞集団の同定や機能など詳細な検討が必要である。 


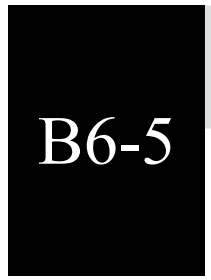

\section{培養筋芽細胞を用いたオステオカルシンによる血糖調節修飾作 用の検討}

$\bigcirc$ 柄慎太郎 ${ }^{1,2}$ 、青沼史子 ${ }^{1,2}$ 、細川隆司 ${ }^{2}$ 、東 $\quad$ 泉 $^{1}$ 、大住伴子 ${ }^{1}$ 、平田雅人 ${ }^{3}$ 、竹内 弘 $^{1}$

(九歯大・歯・ ${ }^{1}$ 口腔応用薬理、 ${ }^{2}$ 口腔再建リハビリテーション、

${ }^{3}$ 九州大院・歯 $\cdot$ 口腔細胞工学)

【目的】近年、骨の代謝と全身の恒常性維持機構との密接な関連が注目されている。中でも骨芽細胞が産 生する主要な骨基質の一つオステオカルシン（OC）が血糖值やエネルギー代謝の調節に重要な役割を持 つことが明らかとなってきた。この作用は骨中に存在するカルボキシル化オステオカルシン（GlaOC） ではなく、骨吸収等により血中に放出された脱カルボキシル化オステオカルシン（ucOC）によるが、作 用機序の詳細はあきらかとなっていない。今回我々はucOCによる糖代謝調節機構を解明するため、血糖 調節に大きな役割を果たす骨格筋由来の細胞株に対するucOCの効果を検討した。

【方法】マウス由来筋芽細胞であるC $2 \mathrm{C} 12$ は $10 \%$ のウシ胎仔血清を添加したダルベッコ改変イーグル培地 (DMEM) にて培養した。実験は細胞株を筋管細胞に分化させて行った。すなわち、コンフルエントになっ た細胞を $2 \%$ ウマ血清含有DMEM中で2日間培養し、その後培地を $1 \%$ ウシ血清アルブミン含有DMEMに 置換して、2日毎に培地を交換しながら分化誘導開始5日後に実験に用いた。細胞内シグナル伝達に関連 するタンパク質のリン酸化は各々の抗リン酸化タンパク質抗体を用いたウェスタンブロット法にて解析 を行った。インスリン刺激による細胞のグルコース取り达み量変化は2-デオキシグルコースの取り込み 量を指標に測定した。

【結果】筋管細胞のインスリン刺激依存的なグルコース取り込み量は ucOC 存在下で増加した。この効果 は細胞内タンパク質リン酸化シグナル経路のうち Erk 経路の阻害剂により抑制された。

【考察】 ucOCはErkのシグナル経路を介してインスリン刺激により誘導されるグルコース取り込み量を調 節することが示唆された。骨代謝と全身の糖代謝の連関機構の一端が明らかとなった。

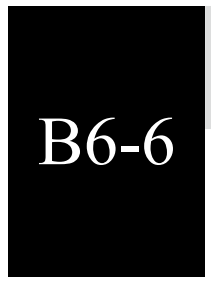

\section{サザンカサポニンとその徐放剤研究の歩み}

○頼仲方一 ${ }^{1} 、 Y u-Z h e n \mathrm{Chen}^{1}$ 、劉 小珍 $^{2}$

( 1 熊本大·医 ·生体機能薬理、市中国上海応用技術学院)

サザンカサポニンは、サザンカ由来の多種サポニンの混合物であり、カメリヤサポゲノールIとカメリ ヤサポゲノールIを含有していることが以前から知られている、このサザンカサポニンは抗炎症、抗浸出、 抗高脂血症、抗心筋虚血などの多くの薬理作用があることを報告された。今回我々は、トウモロコシの 茥および蟹の殼を脱アセチル化して得られたキトサン、カゼイン及びラクトースなどを用いてサザンカ サポニンの徐放性製剤を作製し、それぞれのサザンカサポニン徐放剤とサザンカサポニンを用いて、マ ウス血圧、心拍数や心筋虚血再灌流で誘導される心筋障害に対するそれらの効果を比較解析した。実験 はまず成年オスC57BL6Jマウス(22-25 g)を使用し、サザンカサポニンと徐放剤を薬物の経口投与の最大濃 度が0、100、300、500 mg/kg/d (正常投薬量の100、300、500倍）となるように投与し、動物の半数致死 量（ $\mathrm{C}_{50}$ ) を調べた。サザンカサポニンのみを経口投与と比べ（一日一回で一週間）実験群では、 $\mathrm{C}_{50}$ 濃度 が500 mgであるが、同じ濃度のトウモロコシなど徐放剤を投与した実験群では動物の死亡率が有意に減 少した。さらに、治療量のサザンカサポニンとその三種類徐放剤のマウス虚血期間および再灌流期間に おける期外収縮と心室頻脈を含む不整脈発生率への抑制程度などを観察した。その結果、三種類の徐放 剂も心筋虚血や心筋梗塞で誘導される心筋障害に対する保護作用はサザンカサポニンのみより有意に増 強させる効果が示唆され、その徐放剤はサザンカサポニンの治療効果を増強すると共にサポニンの毒性 の軽減により、漢方薬の新剤型として利用可能であることが示唆された。

参考文献：1). Lai ZF. Book, 2007; 2). Liu XZ, et al: Advanced Materials Research, 2014 


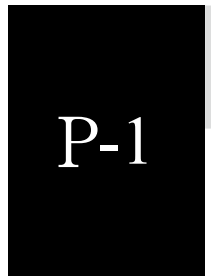

\section{脳室内投与アンジオテンシン II は、中枢性にAT 1 受容体を介し て副腎髄質からアドレナリンを遊離させる}

○中村久美子 ${ }^{1}$ 、清水孝洋 ${ }^{1}$ 、柳田俊彦 ${ }^{3}$ 、根本隆行 ${ }^{4}$ 、清水翔吾 ${ }^{1}$ 、谷内恵介 ${ }^{1}$ 、東洋一郎 ${ }^{2}$ 、

Holmstrom Felix ${ }^{1}$ 、齊藤源顕 ${ }^{1}$

（高知大・医・薬理、 ${ }^{2}$ 脑神経外科、宮崎大 $\cdot$ 医 $\cdot{ }^{3}$ 看護 $\cdot$ 成人 $\cdot$ 老年看護、“薬理）

【目的】アンジオテンシンIIは、主に末梢性に血管を収縮させ血圧上昇を引き起こす生理活性物質として 知られている一方、脳内ではストレスに応答して産生される種々の生理活性物質の一つとして報告され ている。そこで、本研究ではアンジオテンシンIIの中枢性作用について、ストレス反応の一つである交感 神経一副腎髄質系に着目して検討した。

【方法】ウレタン麻酔下に、Wistar系雄性ラットにアンジオテンシンIIを脳室内投与し、投与前、投与後5、 10、30、60、90㧍よび120分に大腿動脈から採血し、血中ノルアドレナリンおよびアドレナリン濃度の経 時変化をHPLC-ECD法にて測定した。更に、急性両側副腎摘除ならびにAT ${ }_{1}$ 受容体遮断薬・バルサルタン およびAT $2_{2}$ 受容体遮断薬・PD123319の脳室内前投与による影響を検討した。また、培養副腎髄質細胞か らのノルアドレナリンおよびアドレナリン遊離へのアンジオテンシンIの直接作用拉よびバルサルタンの 静脈内投与後のアンジオテンシンII脳室内投与についても検討した。

【結果】1）脳室内投与アンジオテンシンIIは、用量依存的に血中アドレナリン濃度を増加させた一方、ノ ルアドレナリン濃度には有意な影響は見られなかった。このアドレナリン濃度変化は一過性で、5及び 10 分をピークに速やかに減衰し、この变化は急性両側副腎摘除により消失した。2）この脳室内投与アンジ オテンシンIIによる血中アドレナリン濃度増加反応は、バルサルタンの脳室内前処置により消失したが、 PD123319の脳室内前処置には影響されなかった。3）アンジオテンシンIIは培養副腎䯣質細胞へ直接作用 して、ノルアドレナリンおよびアドレナリン遊離を経時的に増加させた。4）アンジオテンシンII脳室内 投与による血中アドレナリンン濃度増加は、バルサルタン静脈内前投与によっては影響を受けなかった。 【結語】脳内アンジオテンシンIIは、脳内AT ${ }_{1}$ 受容体を介して副腎髄質系を賦活し一過性に血中アドレナリ ン量を増加させることが示唆された。

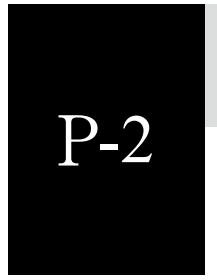

\section{アストロサイトの培養環境制御によるシナプス伝達のパラダイ 厶 \\ ○星山貴志 ${ }^{1}$ 、岩本彩緒里 ${ }^{1}$ 、武田琴水 ${ }^{1} 、$ 青沼有紀 ${ }^{2}$ 、庭野道夫 ${ }^{2} 、$ 野田百美 3 \\ 桂林秀太郎 ${ }^{1}$ 、岩崎克典 ${ }^{1,4}$ \\ ('福岡大・薬・臨床疾患薬理、事東北大・電気通信研・ナノ分子デバイス、 \\ ${ }^{3}$ 九州大院 · 薬 · 病態生理、 ${ }^{4}$ 福岡大 $\cdot$ 加歯令脳科学研)}

脳の神経回路は神経細胞であるニューロンとグリア細胞で構成されており、脳内のグリア細胞はとり わけアストロサイトが占めている。グリア細胞はシナプス形成や知的機能発達の一役を担っているとさ れており、グリア細胞、シナプス, 知的機能の三者間には密接な関倸がある。また、高等動物ほど脳内 グリア細胞が多く、前述を踏まえるとグリア細胞の脳内占拠率が高次脳機能を獲得する上で鍵を握って いる可能性があり、それゆえシナプスの機能に影響していると思われる。本研究ではグリア細胞の脳内 占拠を “数” と“面積” の二方向からアプローチを試みた。アストロサイトの数ないし面積を実験的に 制御及びドット状に培養後、ニューロンを播種、共培養したオータプス培養標本を作製し、パッチクラ ンプ法によりシナプス機能の決定因子がアストロサイトの数（数量依存）なのか、あるいは面積（領域 依存）なのかを検討した。先ずアストロサイト培養面積を一定に保ちつつ、培養アストロサイト数を変 えてオータプス標本を作製した。結果、6個程度の共培養では十分なシナプス伝達は得られなかった。し かし12個以上のアストロサイトと共培養すれば、オータプス標本に扮けるシナプス伝達は十分に観察で きた。このことは、シナプス伝達を構築するためのin vitroに打けるアストロサイト数の必要条件は6-12 個の間であることを意味する。一方、アストロサイト培養面積を40,000～250,000 $\mu \mathrm{m}^{2}$ に変化させてもシ ナプス伝達は十分かつ同等であったことから、十分なシナプス伝達を得るために重要なのは、共存する アストロサイトの数量であると結論した。現在、シナプス伝達を構築するためのアストロサイト最小数 を同定するための実験を計画中であり、アストロサイト環境の变化が高次脳機能獲得の真相に迫る“Key 一真実の扉の鍵”になりうるか妄想中である。 


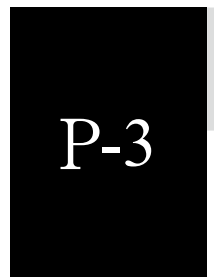

\section{TNF- $\alpha$ に対する脳ペリサイト応答を介するミクログリア活性化 機構}

○船越美帆 ${ }^{1} 、$ 松本純一 ${ }^{2}$ 、高田芙友子 ${ }^{1}$ 、道具伸也 ${ }^{1}$ 、町田 崇 ${ }^{1}$ 穴井佑佳 ${ }^{1}$ 、

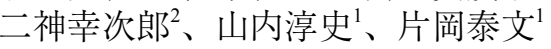

(福岡大·薬・1薬学疾患管理、凑務薬郕)

【背景】脳ペリサイトは神経一血管ーグリア細胞より構成されるNeurovascular Unit (NVU)の構成細胞で ある。我々は、NVUを構成する脳血管内皮細胞、ペリサイト、アストロサイト、ミクログリアの中では、 ペリサイトが炎症性サイトカインであるTNF- $\alpha$ 刺激に最も応答し、IL-6を含む様々な炎症に関連する液性 因子を産生することを明らかにした。さらにTNF- $\alpha に$ 答したペリサイトは、脳内炎症に関与するミク ログリアの活性化を誘導した。このミクログリア活性化作用は、NVU細胞の中で最も強かった。従って、 脳内炎症形成において脳ペリサイトーミクログリア連関が重要な役割を果たすと考えられる。しかし、 ペリサイトによるミクログリア活性化機構の詳細は不明である。そこで、我々は、ペリサイトが産生す る炎症関連液性因子に着目し、TNF- $\alpha$ に対する脳ペリサイト応答を介したミクログリアの活性化機構を 追究することを企てた。

【方法・結果】TNF- $\alpha$ をペリサイトーBV-2共培養モデルに処理したところ、BV2の誘導型NO合成酵素 (iNOS) 発現量が有意に増加した。この発現量増加は、TNF- $\alpha て ゙$ 刺激したペリサイトのcondition mediumを BV2に処理した場合にも認められた。従って、ペリサイトによるミクログリアの活性化は、TNF- $\alpha$ に応 答したペリサイトから産生される液性因子によるものと考えられる。他のNVU細胞と異なり、脳ペリサ イトはTNF- $\alpha$ 刺激に著しく応答しIL-6やMIP-1 $\alpha$ を産生する。BV2単層培養系にIL-6およびMIP-1 $\alpha$ を負荷し たところIL-6のみがiNOS発現量を増加させた。また、TNF- $\alpha$ を負荷したペリサイト一BV-2共培養モデル にIL-6中和抗体を添加したところ、BV2のiNOS発現量の増加が有意に抑制された。さらに、TNF- $\alpha$ を処 理したペリサイトのcondition mediumをBV2に処理した場合において、IL-6のシグナル伝達経路の一つで あるSTAT3活性化がBV2において認められた。

【結論】これらの結果は、炎症病態下ではTNF- $\alpha$ に応答した脳ペリサイトがIL-6産生を介してミクログリ アの活性化を誘導することを示している。本研究は、脳疾患の病態進展を回避する上で脑ぺリサイトが 有力な治療標的となる可能性を提示する。

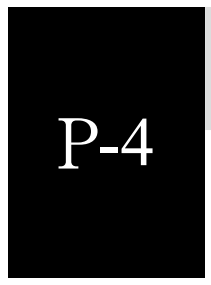

\section{八味地黄丸の空間記憶障害に対する改善作用}

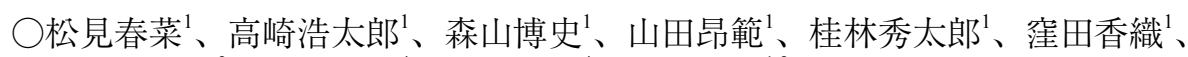

貝沼茂三郎 ${ }^{3} 、$ 三嶋崇晴、坪井義夫 ${ }^{4} 、$ 岩崎克典 ${ }^{1,2}$

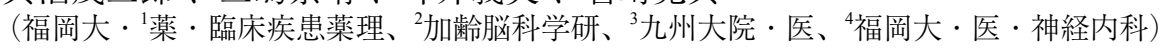

【背景・目的】腎虚に用いられる漢方方剤である八味地黄丸が、記憶障害に効果があることが臨床、非臨 床で報告されている。しかし、アルツハイマー型認知症モデル動物の記憶・学習機能に対する改善作用 は十分に検討されていない。本検討では、一過性脳虚血と $\beta$ アミロイドの脳室内微量注入を組み合わせた アルツハイマー型モデルラット (CI+A $\beta$ ラット) の八方向放射状迷路課題、水迷路試験における空間記憶 障害に対する八味地黄丸の効果を検証した。

【方法】八方向放射状迷路課題により課題を学習した9週齢のWistar系雄性ラットに10分間の単回脳虚血を 行った後に、虚血日を含め7日間aggregate体 $\beta$ アミロイドの脳室内投与および八味地黄丸 $(1000 \mathrm{mg} / \mathrm{kg})$ の 経口投与を行った。また、水迷路試験により課題を学習した9週齢の雄性ラットに同様の処置を施し、八 味地黄丸 $(1000 \mathrm{mg} / \mathrm{kg})$ の評価を行った。両課題とも八味地黄丸の最終投与1時間後に再生試行を行った。 さらに、水迷路試験での評価では $\mathrm{CI}+\mathrm{A} \beta$ ラットに虚血日から 22 日目より7日間八味地黄丸 $(1000 \mathrm{mg} / \mathrm{kg})$ を 経口投与した場合の効果を検討した。

【結果】八方向放射状迷路課題で八味地黄丸は $1000 \mathrm{mg} / \mathrm{kg}$ の用量で、 $\mathrm{CI}+\mathrm{A} \beta$ 処置によって減少した正選択 数に影響しなかったが、 $\mathrm{CI}+\mathrm{A} \beta$ 処置によって増加した誤選択数を有意に減少させた。水迷路試験で八味 地黄丸 $(1000 \mathrm{mg} / \mathrm{kg})$ はCI+A $\beta$ 処置によって延長したtime to platformを1週経過時点、4週経過時点ともに 有意に短縮した。

【考察】本検討より、八味地黄丸は空間記憶障害に対して改善作用があることが明らかとなった。報酬系 である八方向放射状迷路課題、及び逃避系である水迷路試験の両方の評価系で八味地黄丸の効果を検出

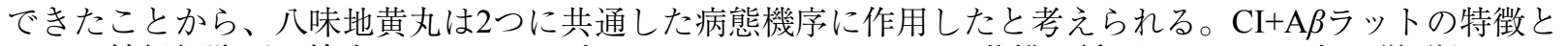
して、神経細胞死が検出されていること、Acetylcholine (ACh) の遊離が低下していることが挙げられる。 したがって、今後は八味地黄丸のAChシグナルへの影響と、神経細胞保護効果の有無についての検討が 必要である。 


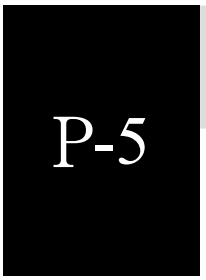

\section{$\mathrm{PC} 12$ 細胞での $\mathrm{H}_{2} \mathrm{O}_{2}$ 誘導細胞死に対する抑肝散の効果}

○古城戸綾 ${ }^{1}$ 、窪田香織 ${ }^{1,2}$ 、桂林秀太郎 ${ }^{1} 、$ 高崎浩太郎 ${ }^{1,2}$ 、岩崎克典 ${ }^{1,2}$

(福岡大 $\cdot{ }^{1}$ 薬・臨床疾患薬理、 ${ }^{2}$ 加齢脳科学研)

【背景】酸化ストレスは、脳内において、加龄や脳梗塞、アルッハイマー病などの神経変性疾患に関係 があるといわれている。酸化ストレスは、細胞死の誘導、アポトーシス誘導の刺激になることも知られ ている。しかし、酸化ストレスは神経細胞死にどのような影響があるのか詳細はまだ不明であり、酸化 ストレスによる影響や神経細胞死の分子機序の解明が求められている。そこで、神経モデル細胞である PC12細胞において、酸化ストレスが細胞の生存・分化・増殖にかかわる経路に与える影響、さらに酸化 ストレスによる細胞死に対する薬物の効果を検討した。我々はアルッハイマー病モデルラットにおいて 抑肝散が海馬の神経細胞死を抑制することを報告している。そこで、抑肝散には酸化ストレスによる神 経細胞死を抑制することが予想された。

【方法】酸化ストレスとして $\mathrm{H}_{2} \mathrm{O}_{2}$ 処置を行った。 $\mathrm{H}_{2} \mathrm{O}_{2}$ 処置により $\mathrm{PC} 12$ 細胞の生存率に与える影響、 $\mathrm{H}_{2} \mathrm{O}_{2}$ 処置による細胞死に対する抑肝散の効果を、WST-1 assayで測定した。アポトーシス実行因子である Caspase 3、細胞の生存・分化・増殖などに関わるERK、Aktは、Western blot法を用いて測定した。

【結果】 $\mathrm{H}_{2} \mathrm{O}_{2}$ 処置により細胞死が誘導され、Caspase 3 は $\mathrm{H}_{2} \mathrm{O}_{2}$ 処置により活性化した。また、抑肝散は $\mathrm{H}_{2} \mathrm{O}_{2}$ 処置によって低下した細胞生存率を改善した。ERK、Aktは、 $\mathrm{H}_{2} \mathrm{O}_{2}$ 処置によりいずれも活性化が見ら れた。その活性化は、抑肝散処置により促進した。

【考察】PC12細胞において $\mathrm{H}_{2} \mathrm{O}_{2}$ による酸化ストレス処置ではアポトーシスが起こり、ERK、Aktの活性化 により、細胞の分化・増殖が促進している。抑肝散は $\mathrm{H}_{2} \mathrm{O}_{2}$ 酸化ストレス下で、細胞の分化・増殖をさら に促進し、アポトーシスを抑制していることが考えられる。酸化ストレスによる細胞死に関わる蛋白や 因子の研究は、アルツハイマー病を始めとする神経変性疾患の治療薬につながると考える。

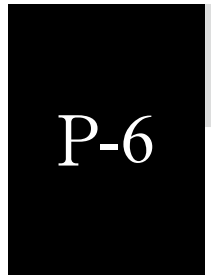

\section{オピオイド $\kappa$ 受容体アゴニストナルフラフィン誘導体の CellKey ${ }^{\mathrm{TM}}$ Systemを用いた受容体作動活性評価}

$\bigcirc$ 佐藤汐莉 ${ }^{1,2}$ 、根本悦子 ${ }^{1,2} 、 川$ 合田恵美 ${ }^{1,2}$ 、横山明信 ${ }^{2}$ 、西村 瞳 $^{2} 、$ 宮野加奈子 ${ }^{2} 、$

平山重人 ${ }^{1}$ 、白石成二 ${ }^{2}$ 、長瀬 博 ${ }^{3}$ 藤井秀明 1 、上園保仁 2

('北里大・薬・生命薬化、2国立がん研・がん患者病態生理、筑波大·IIIS)

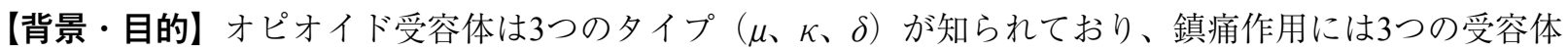
が関与し、依存性は $\mu$ 受容体が関与すると考えられている。作動薬であるナルフラフィンは 2009 年に止 痒薬として上市されたが、鎮痛用量において鎮痛作用と鎮静作用の分離が十分にできなかったため、適 応を鎮痛薬から止痒薬に変更して開発されたという経緯がある。薬物嫌悪性のない火作動性鎮痛薬を設計 するためには、K受容体に対して選択的に作動活性を発現させる必須構造を明らかにする必要がある。本 研究では、新しい活性評価法として、評価対象細胞に標識化合物などを添加する必要のない、いわゆる label-freeでアッセイできるCellKey ${ }^{\mathrm{TM}}{ }$ Systemを用いることにより、作成したナルフラフィン誘導体のK受 容体への作動活性、選択性の評価を行った。

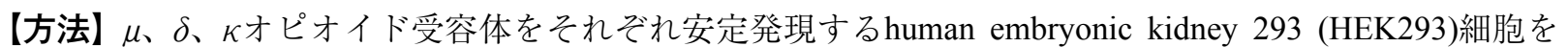
作製し、CellKey ${ }^{\mathrm{TM}}$ 専用の96wellプレート上で培養した。その後各誘導体を添加し、受容体刺激で変化す る細胞電気抵抗の変化をリアルタイムでCellKey ${ }^{\mathrm{TM}}$ Systemを用いて測定した。

【結果】本実験では合成したナルフラフィン誘導体を大きく3つに大別し評価した（1)べンゼン環を有す る誘導体群、(2)ベンゼン環をシクロヘキセン環に置換した誘導体群、(3)ベンゼン環を除去した誘導体群)。 その結果、(1)群は、 $\mu 、 \kappa 、 \delta$ 受容体に対する $\mathrm{EC}_{50}$ および $\mathrm{E}_{\max }$ はナルフラフィンの各受容体に対する值とほぼ 同程度であり、 $\mathrm{EC}_{50}$ は $\kappa$ 受容体が $\mu 、 \delta$ 受容体と比較して最も小さかった。(2)群でも (1) と同様の傾向が認め られた。(3)群は $\delta 、 \kappa$ 受容体に対する作動活性がナルフラフィンと比較して低下する傾向が見られた。

【考察】ナルフラフィンのベンゼン環部位はK受容体への作動活性上昇、および選択性の向上に寄与する。 この活性上昇・選択性はベンゼン環をシクロヘキセン環へ置換しても認められた。 


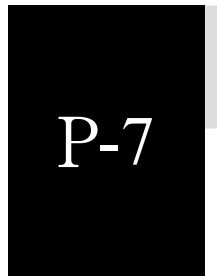

\section{本邦で用いられている医療用麻薬の薬理学的特性の解析}

- CellKey ${ }^{\mathrm{TM}}$ システムならびに新規インターナリゼーションアッセイを用いて -

$\bigcirc$ 川合田恵美 ${ }^{1,2}$ 、横山明信 ${ }^{2,3}$ 、根本悦子 ${ }^{1,2}$ 、佐藤汐莉 ${ }^{1,2}$ 、西村 瞳 $^{2,3}$ 、宮野加奈子 ${ }^{2}$ 、

山川 央 $^{4} 、$ 平山重人 ${ }^{1} 、$ 白石成二 ${ }^{2} 、$ 長瀬隆弘 ${ }^{4} 、$ 藤井秀明 ${ }^{1} 、$ 上園保仁 ${ }^{2}$

( ${ }^{1}$ 北里大・薬、 ${ }^{2}$ 国立がん研・がん患者病態生理、 ${ }^{3}$ 東京理科大院・薬、 ${ }^{4}$ かずさDNA研)

【目的】本邦でがん性疼痛に用いられる医療用麻薬、モルヒネ、フェンタニル、オキシコドンは $\mu, \delta, \kappa オ$ ピオイド受容体 $(\mu \mathrm{OR}, \delta \mathrm{OR}, \kappa \mathrm{OR})$ のうち、主に $\mu \mathrm{OR}$ 介して鎮痛作用を発揮することが知られているが、 各薬剤で副作用発生の様式が異なること、さらに $\mu \mathrm{OR}$ のならず $\delta \mathrm{OR}, \kappa \mathrm{OR}$ 々対しても作用することが報 告されている。しかし、それぞれの医療用麻薬の $\delta \mathrm{OR}, \kappa \mathrm{OR}$ 対する作用は不明な点が多い。本研究では、 $\mu \mathrm{OR}, \delta \mathrm{OR}, \kappa \mathrm{OR}$ それぞれ安定的に発現する細胞を構築し、各医療用麻薬の受容体活性及び急性鎮痛耐

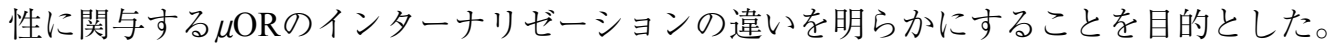

【方法】HaloTag ${ }^{\circledR}, T 7-t a g$, Myc-tagを各々融合した $\mu \mathrm{OR}, \delta \mathrm{OR}, \kappa \mathrm{OR}$ を安定発現するHuman Embryonic Kidney 293（HEK293）細胞を作製し、細胞反応を電気抵抗変化として検出できるCellKey ${ }^{\mathrm{TM}}$ システムを用い、 各医療用麻薬の薬物応答を解析した。 $\mu \mathrm{OR}$ のインターナリゼーションは、新たに開発された 性HaloTag ${ }^{\circledR}$ Ligandを用いてインターナリゼーションを経時的に可視化し、Cellomics ${ }^{\mathrm{TM}}$ ArrayScan $^{\circledR}$ VTI Systemにより客観的に解析した。

【結果・考察】CellKey ${ }^{\mathrm{TM}}$ アッセイの結果より、用いたすべての医療用麻薬は $\mu \mathrm{OR}$ に対して最も高い活性 を示し、各麻薬製戍に打ける $\mathrm{EC}_{50}$ はフェンタニル<モルヒネ<オキシコドンであった。モルヒネはすべ ての受容体に対し低濃度から活性が認められた。一方、オキシコドンは $\kappa$ ORに対して活性が認められな かった。また、インターナリゼーション解析では、モルヒネ、オキシコドンは $\mu \mathrm{OR}$ インターナリゼーショ ンをほとんど引き起こさなかったのに対し、フェンタニルのみが顕著な $\mu \mathrm{OR}$ インターナリゼーションを 引き起こすことが明らかとなった。以上より、各医療用麻薬は $\mu \mathrm{OR}$ に最も強い活性があるという特性を 有しているにも関わらず、 $\mu \mathrm{OR}$ インターナリゼーションに関しては異なる特性を有していた。このこと が副作用発生の違いにも関与することが考えられた。

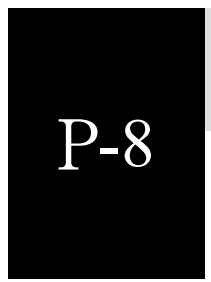

\section{ウシ副腎髄質細胞におけるチロシン水酸化酵素とカテコールア ミン分泌に及ぼすアピゲニンの影響}

○馬場宏佳、松田有希、豊平由美子、李 暁佳、吉永有香里、高橋圭太、柳原延章 (産業医大·医・薬理)

【目的】フィトケミカルとは、植物が紫外線の害や虫などから自らの身を守るために作りだした物質で、 植物性食品の「色」「香り」「苦み」などの成分で、第7の栄養素として注目されている。その種類は、数 千種類〜一万種類あるといわれ、カロテノイド群、ポリフェノール・フラボノイド群、硫黄化合物など に分類される。アピゲニンは、パセリ、セロリ、カモミール茶等に含まれるフラボンで、抗酸化作用、 抗炎症作用、抗がん作用、抗腫瘍形成作用などが報告されている。また、高用量では抗不安薬や精神安 定剤としての効果がある。MAPキナーゼの阻害剤としても知られている。神経系への影響を検討する目 的で、交感神経系の機能分析においてモデル系として用いられている培養ウシ副腎髄質細胞でのアピゲ ニンのカテコールアミン（CA）分泌および生合成への影響を検討した。

【方法】コラゲナーゼ処理により分離・培養したウシ副腎髄質細胞を用いて、CA分泌とFura-2を指標とし て細胞内 $\mathrm{Ca}^{2+}$ 濃度を測定した。CA合成の律速酵素であるチロシン水酸化酵素のリン酸化をウエスタンブ ロッティング法により測定した。

【結果】アピゲニンはニコチン性アセチルコリン受容体や電位依存性ナトリウムチャネル、電位依存性カ ルシウムチャネルを介したCA分泌を濃度依存性（3-100 $\mu \mathrm{M})$ に抑制した。アピゲニンはチロシン水酸 化酵素のセリン 31 と40のリン酸化を促進した。アピゲニンはアセチルコリン刺激よるチロシン水酸化酵 素のセリン31のリン酸化を抑制した。

【考察】アピゲニンは副腎髄質細胞において、イオンチャネル機能を阻害して、CA分泌を抑制すること が示唆された。さらに、チロシン水酸化酵素のリン酸化に影響を及ぼすことは明らかになったが、その 作用機序については検討中である。 


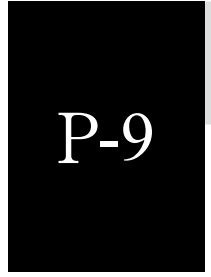

食品摂取による自律神経バランスの計測とその食品機能評価の基盤研究（第1 報）－健常者におけるお茶の旨味成分テアニンの自律神経バランスへの影響 -

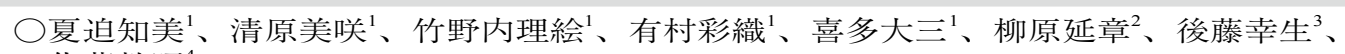
佐藤教昭 ${ }^{4}$

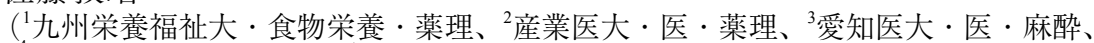

産業医大・教育研究施設)

【目的】自律神経は、気温の変化や精神的ストレスなど外界からの刺激に対して、生体の恒常性を維持す る機能を担っており、この自律神経における交感・副交感神経活動のバランスは、生体の恒常性の維持 にはきわめて重要である。本研究は、食品摂取による自律神経バランスの計測とその食品機能評価の基 盤研究をすることにある。今回、緑茶に含まれる遊離アミノ酸のなかで最も含有量が多く、末梢および 中枢神経系への作用が注目されているLーテアニン（テアニン）について、健常者におけるテアニンの自 律神経バランスの影響を検討した。

【方法】本研究は九州栄養福祉大学並びに産業医科大学倫理委員会での承認及び健常者による同意書を得 て実施された。自律神経に対する影響は心拍変動解析システム「自律神経機能のレーダーチャート式バ ランス評価法」（自律神経, 35巻4号 410-418頁, 1998) に準拠し、テアニン（200mg）服用前および30〜 40分後の心電図信号を測定し、同評価法により解析した。テアニンは市販のサプリメントを、プラセボ として乳糖を各々に服用させ、二重盲検法より検討した。また、各実験の実施前には直近の体調や精神 状態に関するアンケートを行った。

【結果および考察】自律神経バランスにおけるテアニン飲用後の変化において、テアニン飲用後に副交感 神経系の活動が優位になる測定例が観察されたが、有意な差は認められなかった。脳波を指標としたテ アニンの効果について、生体に対して集中力を向上させる作用や気分を落ち着かせリラックスさせる作 用が報告されている（Nobre AC et al. Asia Pac J Clin Nutr 17 167-168, 2008)。今回使用した自律神経バ ランス測定法は、臨床で普及している心電図のR-R間隔変動を用いる方法であるが、このR-R間隔は、視 床下部から心臓へ投射する2つの相反する交感・副交感神経活動を反映しており、その遠心性インパルス による心拍数調節のバロメーターとみなされる。また、この視床下部はその上位中枢である感情や情緒 をコントロールする大脳辺縁系に大きく影響を受けることから、テアニンによる副交感神経系への影響 において、中枢神経系への関与の可能性も推測される。

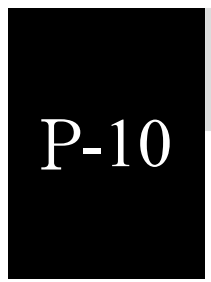

\section{両腎摘出急性腎障害に伴う肺aquaporin-5発現変動における インドキシル硫酸の関与}

○薮内希実 ${ }^{1} 、$ 佐潟雅隆 ${ }^{1} 、$ 西郷智香 ${ }^{1} 、$ 山本悠子 ${ }^{1}$ 、米田 剛 ${ }^{1} 、$ 野村結衣 $^{1} 、$

西 一彦 ${ }^{3}$ 、城野博史 ${ }^{1,2}$ 、齋藤秀之 $之^{1,2}$

( ${ }^{1}$ 熊本大 $\cdot$ 薬 $\cdot$ 臨床薬物動態、熊本大病院 $\cdot{ }^{2}$ 薬片部、 ${ }^{3}$ 血液浄化療法部)

【目的】急性腎障害は、急激な腎機能低下の結果、体液の恒常性が維持できなくなった病態である。急性 腎障害の病態理解および予防・治療法の進展にも関わらず、その死亡率は高い。急性腎障害に起因する 死亡率は、同時に誘発される急性肺障害（ALI）や急性呼吸促迫症候群（ARDS）と関連することが報告 されている。この要因として、肺ナトリウム・水チャネルの機能低下がALI/ARDSの発症に関与している と推定されているが、詳細な分子機序については不明である。インドキシル硫酸（IS）は、腎機能低下 に伴い血中と臓器中に蓄積し酸化ストレスや組織障害を惹起する尿毒症物質として知られている。本研 究では、両腎摘出 $(\mathrm{BNx})$-急性腎障害ラットを用い、肺AQP-5の発現変動に扔けるISの関与について精 査した。

【方法】6週齢SD系雄性ラットを用い、BNx前後に経口吸着剤AST-120（2.5g/kg）を経口投与し、48h時 点で血清および藏器を採取した。血清・臓器中IS濃度、肺AQP-5及びNa,K-ATPaseタンパク発現量、血中 interleukin(IL)-6濃度を評価した。

【結果・考察】BNx後48h時点において血清クレアチニン $(\mathrm{SCr})$ 、血中尿素窒素（BUN）及び血清中IS濃 度が顕著に上昇すること、肺AQP-5発現量が著明に減少しダウンレギュレーションしていることを認め た。一方、AST-120投与群では血清、臓器（肺、肝臓）中のIS蓄積が有意に抑制され、肺AQP-5発現量も 回復したが、SCr、BUN並びにNa,K-ATPase発現量には影響が見られなかった。また、BNx後4h時点にお いて血清中IL-6濃度はAST-120投与による影響を受けなかった。BNx-急性腎障害に伴い肺AQP-5のダウン レギュレーションが生じること、この発現制御にISが密接に関与している可能性を見出した。 


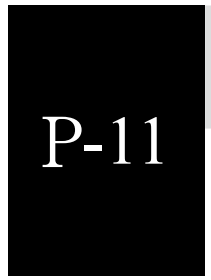

\section{虚血性急性腎障害ラットにおけるインドキシル硫酸産生阻害薬 の腎保護効果}

○小山直子 ${ }^{1}$ 、西郷智香 ${ }^{1}$ 、佐潟雅隆 ${ }^{1}$ 、野村結衣 ${ }^{1}$ 、松永里香 ${ }^{1}$ 、城野博史 ${ }^{1,2}$ 、西 一彦 ${ }^{3}$ 、 齋藤秀之 ${ }^{1,2}$

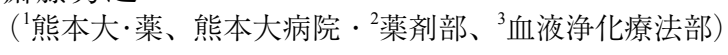

【目的】急性腎障害 (AKI) は出血や体液の亦失、生体腎移植等の要因により惹起される病態である。腎 機能低下に伴い血中に蓄積する尿毒症物質インドキシル硫酸（IS）は、インドールが腸管吸収された後、 肝臓でCYP2A6、CYP2E1及び硫酸転移酵素 (SULT) 1A1により代謝産生される。血中ISは、腎近位尿 細管に局在する有機アニオントランスポータを介して細胞内に取り达まれた後、尿中排泄される。これ まで、ラット肝蔵S9画分を用いたIS産生阻害薬物スクリーニング評価系を確立し、SULT阻害薬物が肝組 織におけるIS産生を抑制すること、虚血再灌流急性腎障害 (IR-AKI) ラットにおいて一部のSULT阻害薬 物が血中IS蓄積を減少させ腎保護効果を示すことを報告した。本研究では、酵素阻害に着目した新規IS 産生阻害物質探索を企図し、種々の構造を有する化合物のスクリーニングを行った。また、AKIラット を用いてスクリーニングで見出したIS産生阻害薬物を投与し、IS蓄積抑制及び腎障害軽減効果について 比較精査した。

【方法】6週齢SD系雄性ラットを使用した。肝臓S9画分を用いたスクリーニングにより約180化合物につ いて評価した。AKIラットにIS産生阻害薬物をIR後、6時間毎に投与量 $(10 \mathrm{mg} / \mathrm{kg})$ を3回静脈内投与し た。48時間後に血液及び蔵器サンプルを採取し、血清IS濃度及び血清クレアチニン (SCr)、血中尿素窒素 (BUN) について評価した。

【結果・考察】スクリーニングの結果、9化合物にIS産生阻害効果が認められ、最も強い阻害効果を示 したmeclofenamateは1.34 $\mu \mathrm{M}$ の $\mathrm{IC}_{50}$ 值を示した。AKIラットでは血中IS濃度が顕著に上昇したのに対し、 meclofenamate投与群では低下し、さらにSCr及びBUNは有意に減少した。AKIラットに対する上記化合物 のIS蓄積抑制並びに腎障害軽減効果から、血清もしくは腎組織中ISがIR後の腎障害進展に少なくとも一 部関与する可能性が示唆された。本知見は、硫酸抱合型尿毒症物質の産生・蓄積阻害に基づく腎障害進 展予防・治療法の可能性を支持する基盤情報と考える。

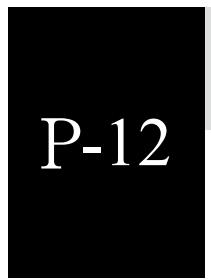

\section{Angiotensin II type 1 receptor blocker, olmesartan ameliorates corpus cavernosum damages in the spontaneously hypertensive rat}

Holmstrom Felix, Shimizu Shogo, Shimizu Takahiro, Higashi Youichirou,

Nakamura Kumiko, Saito Motoaki

(Department of Pharmacology, Kochi Medical School, Kochi University)

Aim: In the study, we investigated the possible effect of olmesartan, an angiotensin II receptor blocker (ARB), or nifedipine, an L-type calcium channel blocker, on penile dysfunction in the spontaneously hypertensive rat (SHR).

Material and Methods: Twelve-week-old male SHRs were administered with olmesartan (1 or $3 \mathrm{mg} / \mathrm{kg}$, per orally (p.o.)) or nifedipine $(30 \mathrm{mg} / \mathrm{kg}$, p.o.) once a day for 6 weeks. SHRs and Wistar rats were used as agedmatched normotensive controls. Penile function was evaluated by organ bath studies with norepinephrine-induced contractions and acetylcholine-induced relaxations. Penile malondialdehyde and cGMP concentrations, and mRNA levels of endothelial and neuronal NO synthase (eNOS and nNOS) were measured.

Result: The SHR showed significantly increased blood pressure and malondialdehyde concentrations, norepinephrine-induced hyper-contractions and acetylcholine-induced hyporelaxations, and decreased cGMP concentrations, eNOS and nNOS mRNA levels in the penile tissue compared to the Wistar rat. Both olmesartan and nifedipine significantly decreased blood pressure, increased cGMP and normalized the hyper-contractions and hypo-relaxations observed in the SHR group. However, olmesartan but not nifedipine decreased the malondialdehyde concentrations and increased mRNA levels of eNOS and nNOS in the penis.

Discussion: Our data indicates that the hypertension-associated penile dysfunction could be better treated with ARBs such as olmesartan compared to calcium channel blockers, such as nifedipine. 


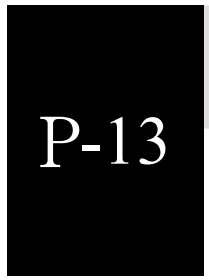

\section{P2Y6受容体阻害化合物MRS2578の化学特性に着目した新たな 心血管病治療薬の探索}

重松智博 ${ }^{1}$ 、西村明幸 ${ }^{2}$ 、Caroline Sunggip ${ }^{2}$ 、西田基宏 ${ }^{1,2}$

$\left({ }^{1}\right.$ 九州大・薬・創薬育薬産学官連携、

${ }^{2}$ 自然科学研究機構岡崎統合バイオサイエンスセンター・心循環シグナル研究部門)

プリン作動性P2Y6受容体（P2Y6R）は、細胞の貪食や遊走など様々な生理機能の発現に関わるG蛋白 質共役型受容体である。我々は、唯一のP2Y6RアンタゴニストであるMRS2578が、心血管リモデリング を改善することをマウスレベルで明らかにしてきた。一方、P2Y6R欠損マウスでは、圧負荷誘発性の突 然死が増加するという知見も得ている。これらの矛盾した結果は、MRS2578がP2Y6Rのbiased ligand とし て作用している可能性を示している。そこで我々は、MRS2578がP2Y6Rに作用する分子機構を解明する ことで、P2Y6R選択的な新しい心血管病治療薬の探索を試みた。

MRS2578はその構造中にイソチオシアネート基 $(-\mathrm{N}=\mathrm{C}=\mathrm{S})$ を2つ有している。イソチオシアネート基中 の炭素原子は親電子作用があり、この構造を持つ化合物は抗酸化作用を示す。野生型 $(\mathrm{P} 2 \mathrm{Y} 6 \mathrm{R}(+/+))$ マ ウスから単離した血管平滑筋細胞にMRS2578を処置したところ、抗酸化タンパク質hemeoxygenase (HO)-1 の有意な発現増加が認められた。これに対し、P2Y6R欠損（P2Y6R(-/-)）マウス由来の平滑筋細胞で は、MRS2578処置によるHO-1誘導がほぼ完全に抑制された。この結果は、MRS2578がP2Y6Rへの親電 子修飾を介してHO-1を発現誘導する可能性を示している。実際、キャベッやダイコンなどに含まれるイ ソチオシアネート含有化合物allyl isothiocyanateがP2Y6R阻害作用をもつかどうか調べたところ、P2Y6R 選択的アゴニスト3-phenacyl-UDP刺激で誘発されるP2Y6R依存的な細胞内カルシウム濃度の上昇がallyl isothiocyanate前処置によって完全に抑制された。これらの結果は、allyl isothiocyanate様のイソチオシア ネート含有化合物が、ヌクレオチド誘発性P2Y6Rシグナリングを阻害する一方でP2Y6Rへの親電子修飾 を介して抗酸化作用を発揮する新たな心血管病治療薬となる可能性を示している。

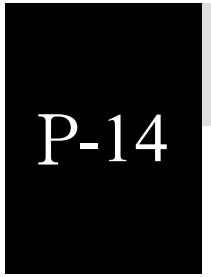

\section{ミトコンドリアリモデリング抑制を主眼とした新規心不全治療薬の同 定 \\ ○永井直杜 ${ }^{1}$ 外山喬士 ${ }^{2}$ 、石川達也 ${ }^{1,3}$ 、西田基宏 ${ }^{1,2}$ \\ ('九州大·薬・創薬育薬産学官連携、 \\ ²自然科学研究機構岡崎続合バイオサイエンスセンター・心循環シグナル研究部門、味の素製薬)}

我々は、心筋梗塞後のマウス心臓の非梗塞領域において内在性親電子物質が生成され、これらが特定 のタンパク質システイン残基（Cys）に機能修飾（親電子修飾）を与えることで慢性心不全を誘発する 可能性を示してきた。一方、メチル水銀 $(\mathrm{MeHg})$ は心血管リスクを高める外因性親電子物質（環境污染物 質）であることが知られているものの、MeHgが心血管リスクを高める原因についてはよくわかっていな い。そこで我々は、MeHgによる心毒性のメカニズム解析を起点に、親電子物質を介する慢性心不全の 新たな創薬標的分子を同定し、創薬育薬につなげることを試みた。ラット新生児初代心筋細胞に細胞毒 性を誘発しない濃度 $(<0.1 \mu \mathrm{M})$ の $\mathrm{MeHg}$ を曝露したところ、ミトコンドリアの分裂とそれに伴うNADHデ ヒドロゲナーゼ (MTT) 活性执よびATP産生量の低下が観察された。質量分析の結果、MeHgはミトコン ドリア分裂促進GTP結合タンパク質であるラットdynamin-related protein 1 (Drp1)のCys624残基に直接結合 し、Drp1の活性化を引き起こすことが明らかとなった。MeHg処置によるMTT活性低下を指標に当研究 室保有の既承認薬／試薬ライブラリーを用いてスクリーニングを行ったところ、細胞膜イオンチャネル を阻害する化合物が複数ヒットした。実際、ヒット化合物の1つがマウス心筋梗塞後の慢性心不全を強く 改善させることが確認できた。以上の結果は、親電子シグナル防御を主眼とする本法が慢性心不全治療 薬の新たなストラテジーとなることを強く示唆している。 


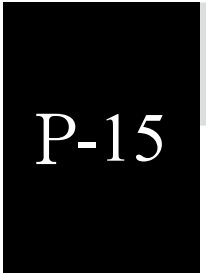

\section{末梢循環障害を改善する新規TRPC3/6選択的阻害薬の同定}

○松金良祐 ${ }^{1}$ 島内 司 $^{1,2}$ 冨田拓郎 ${ }^{1,2}$ 西田基宏 ${ }^{1,2}$

$\left({ }^{1}\right.$ 九州大 $\cdot$ 薬・創薬育薬産学官連携、

${ }^{2}$ 自然科学研究機構岡崎統合バイオサイエンスセンター・心循環シグナル研究部門)

末梢循環障害は下肢閉塞性動脈硬化症（PAD）の主たる病態であり、末梢血流低下による下肢機能不 全により生命予後を悪化させる要因として注目されている。PADに対して外科的治療や薬物治療が主に 行われているものの、有効な薬物はシロスタゾール(CLZ)だけであり、PADは今なお薬物治療のアンメッ トニーズの大きい疾患といえる。我々は最近、CLZによる下肢虚血後の末梢血流改善効果が、血管平滑 筋細胞に発現する非選択的陽イオンチャネルTRPC6のリン酸化を介したチャネル活性阻害と強く相関す ることを明らかにした。さらに、血管平滑筋細胞特異的なTRPC6チャネルの機能阻害が下肢虚血後の血 流回復を有意に促進させたことから、TRPC6がPADの新たな創薬標的分子となることが強く示唆された。 そこで我々は、当部門保有の既承認薬ライブラリーを用いてTRPC6阻害化合物のスクリーニングを行い、 7種類の化合物を得ることに成功した。各薬物を浸透圧ポンプに含ませ、Balb/cマウスの下肢虚血モデル に持続投与し、薬効解析を行った結果、CLZと同程度の末梢血流改善効果を示す新たな化合物として、 1-benzilpiperidine誘導体(1-BP) を得ることに成功した。1-BPはTRPC3およびTRPC6のチャネル活性を選択 的に抑制し、TRPC7チャネルやストア作動性Ca $\mathrm{Ca}^{2+}$ チャルを阻害しなかった。1-BPは、血管新生よりむ しろ成熟血管を増加させることにより、下肢虚血後の末梢血流回復を有意に促進した。驚くべきことに、 1-BPは下肢虚血1週間後から投与を開始してもその後の慢性的な末梢循環障害や運動機能低下を有意に改 善した。さらに、家族性高コレステロール血症モデル（LDL受容体ノックアウト）マウスに1-BPを処置 したところ、下肢虚血後の内皮由来血管弛緩因子産生低下が有意に改善されることもわかった。以上の 結果は、TRPC6チャネルが新規PAD治療薬の新たな分子標的となることを強く示唆している。

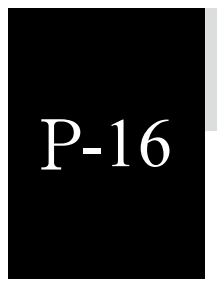

\section{肺高血圧症モデルマウスにおける血管構築細胞の低酸素応答転写因子 の役割 \\ ○井口道代 ${ }^{1} 、$ 富田紀子 ${ }^{2} 、 今$ 西正樹 ${ }^{1} 、$ 黑部裕嗣 ${ }^{3} 、$ 菅澤典子 ${ }^{3}$ 、佐藤 至 $^{1}$ 、松永慎司 ${ }^{1} 、$ 冨田修平 ${ }^{1}$ \\ （鳥取大·医· 病態解析医学・分子薬理、病態情報内科、 \\ 徳島大院・ヘルスバイオサイエンス研・器官病態修復医学・心臟血管外科}

動脈性肺高血圧症は血管収縮と炎症・増殖といった血管リモデリングにより肺動脈抵抗が増加する予 後不良の疾患である。肺高血圧症の新たな治療法の確立のために肺高血圧症の発症・増悪の分子メカニ ズムの解明が必要とされている。重症の閉塞性肺疾患や肺胞低換気症候群に起因する肺高血圧症の発症 には、肺血管床の減少や低酸素性肺血管攣縮が関与することが知られている。低酸素環境下では低酸素 応答因子 (Hypoxia-Inducible factor :HIF) が分解抑制され、細胞分裂や代謝、血管新生、造血などを調節し、 生体の恒常性が保たれている。HIFは肺動脈の複数の病態反応を制御していることが報告されているが、 肺血管構築細胞におけるHIFの詳細な分子メカニズムはわかっていない。

本研究では、血管内皮細胞のHIF-1 $\beta$ と血管平滑筋細胞のHIF-1 $\alpha$ が肺高血圧症の病態に寄与しているか 否かを検討した。まず、Cre-loxPシステムにより作製した血管内皮細胞HIF-1 $\beta$ ノックアウトマウスと血管 平滑筋細胞HIF-1 $\alpha$ ノックアウトマウスを用いてモノクロタリン誘導性肺高血圧症モデルを作製し、右室 心筋重量比・1視野あたりの肺小動脈数・中膜外径比を評価した。これらをそれぞれのコントロールマウ スのモノクロタリン誘導性肺高血圧症モデルと比較すると血管内皮細胞特異的ARNTノックアウトマウ スでは肺高血圧症の病態が抑制されていた。一方、血管平滑筋細胞特異的HIF-1 $\alpha$ ノッアウトマウスで は血管リモデリングは軽減している傾向が見られたが、右室負荷の変化は認められなかった。

これらの結果より、モノクロタリン誘導性肺高血圧症の発症、増悪には血管内皮HIF-1 $\beta$ が関与してい る可能性が示唆された。一方、血管平滑筋HIF-1 $\alpha$ にいては更なる検討が必要であると考えられる。 